\title{
A Survey of Molecular Imaging of Opioid Receptors
}

\author{
Paul Cumming $1,2, * \mathbb{E}$, János Marton ${ }^{3}$, Tuomas O. Lilius ${ }^{4}\left(\mathbb{D}\right.$, Dag Erlend Olberg ${ }^{5}(\mathbb{D}$ and \\ Axel Rominger ${ }^{1, *}$
}

1 Department of Nuclear Medicine, University of Bern, Inselspital, Freiburgstraße 18, 3010 Bern, Switzerland

2 School of Psychology and Counselling and IHBI, Queensland University of Technology, QLD 4059, Brisbane, Australia

3 ABX Advanced Biochemical Compounds, Biomedizinische Forschungsreagenzien $\mathrm{GmbH}$, Heinrich-Glaeser-Strasse 10-14, D-1454 Radeberg, Germany; marton@abx.de

4 Center for Translational Neuromedicine, Faculty of Health and Medical Sciences, University of Copenhagen, 2200 Copenhagen N, Denmark; tuomas.lilius@sund.ku.dk

5 School of Pharmacy, University of Oslo, Norwegian Medical Cyclotron Centre, N-0372 Oslo, Norway and Norwegian Medical Cyclotron Centre Ltd., Sognsvannsveien 20, N-0372 Oslo, Norway;

Dag.Erlend.Olberg@syklotronsenteret.no

* Correspondence: paul.cumming@insel.ch (P.C.); axel.rominger@insel.ch (A.R.); Tel.: +41-31-664-04-98 (P.C.); +41-31-632-26-10 (A.R.)

Academic Editor: Peter Brust

Received: 21 October 2019; Accepted: 13 November 2019; Published: 19 November 2019

\begin{abstract}
The discovery of endogenous peptide ligands for morphine binding sites occurred in parallel with the identification of three subclasses of opioid receptor (OR), traditionally designated as $\mu, \delta$, and $\kappa$, along with the more recently defined opioid-receptor-like (ORL1) receptor. Early efforts in opioid receptor radiochemistry focused on the structure of the prototype agonist ligand, morphine, although $\mathrm{N}$-[methyl- $\left.{ }^{11} \mathrm{C}\right]$ morphine, -codeine and -heroin did not show significant binding in vivo. $\left[{ }^{11} \mathrm{C}\right]$ Diprenorphine $\left(\left[{ }^{11} \mathrm{C}\right] \mathrm{DPN}\right)$, an orvinol type, non-selective $\mathrm{OR}$ antagonist ligand, was among the first successful PET tracers for molecular brain imaging, but has been largely supplanted in research studies by the $\mu$-preferring agonist $\left[{ }^{11} \mathrm{C}\right]$ carfentanil $\left(\left[{ }^{11} \mathrm{C}\right] \mathrm{Caf}\right)$. These two tracers have the property of being displaceable by endogenous opioid peptides in living brain, thus potentially serving in a competition-binding model. Indeed, many clinical PET studies with $\left[{ }^{11} \mathrm{C}\right] \mathrm{DPN}$ or $\left[{ }^{11} \mathrm{C}\right] \mathrm{Caf}$ affirm the release of endogenous opioids in response to painful stimuli. Numerous other PET studies implicate $\mu$-OR signaling in aspects of human personality and vulnerability to drug dependence, but there have been very few clinical PET studies of $\mu$ ORs in neurological disorders. Tracers based on naltrindole, a non-peptide antagonist of the $\delta$-preferring endogenous opioid enkephalin, have been used in PET studies of $\delta$ ORs, and $\left[{ }^{11} \mathrm{C}\right]$ GR103545 is validated for studies of $\mathrm{kORs}$. Structures such as $\left[{ }^{11} \mathrm{C}\right] \mathrm{NOP}-1 \mathrm{~A}$ show selective binding at ORL-1 receptors in living brain. However, there is scant documentation of $\delta-, \mathrm{K}-$, or ORL1 receptors in healthy human brain or in neurological and psychiatric disorders; here, clinical PET research must catch up with recent progress in radiopharmaceutical chemistry.
\end{abstract}

Keywords: opioid receptors; positron emission tomography; radiotracers; $\mu \mathrm{OR}-, \delta \mathrm{OR}-, \mathrm{kOR}-$ and ORL1-ligands; epilepsy; movement disorders; pain; drug dependence

\section{Introduction}

The analgesic and soporific properties of opium have been known since antiquity, perhaps first attested in the detached reveries of Homer's Lotophagi. The sinister side of opium dreams is depicted in Tennyson's version of that story, and more distinctly in the memoires of Thomas de Quincy, who may have had the distinction of establishing a genre of literature, the addiction diary. A key active constituent of the sap of Papaver somniferum was first isolated in 1804 by the apothecary Friedrich 
Wilhelm Sertürner, who named it morphium, later morphine (1). Chemists identified its elemental composition in the $19^{\text {th }}$ century, and efforts to determine its structure were rewarded in 1925, when Gulland and Robinson [1] recommended a structure consistent with the characteristics of morphine and codeine and their degradation products. Subsequent investigations confirmed the correctness of the analytically deduced structure of morphine, culminating in its total synthesis, achieved in the 1950s by Gates and Tschudi [2,3]. The absolute stereochemistry of morphine's five chiral carbons $(5,6$, 9, 13 and 14) was reported by Bentley and Cardwell [4] in 1955, and the first practically realizable morphine total synthesis with reasonable yields was reported by Rice in 1980 [5]. To this day, it is more economical to allow the poppy plant to do the main work of morphine (1) synthesis, although chemists have since produced so many structural variants that one might consider opioid pharmacology to be a discipline in its own right. There have been several reviews of opioid receptor imaging in the past decade [6-8], but we now present a comprehensive update on the the main classes of opioid receptor (OR) ligands used for positron emission tomography (PET), and review clinical findings with this technology. Relevant chemical structures of endogenous opioid peptides and representative small molecule opioid receptor ligands are depicted in Figure 1.

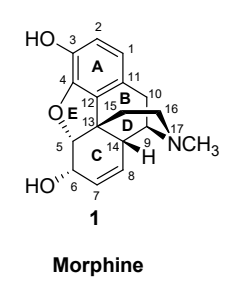

$5 R, 6 S, 9 R, 13 S, 14 R$

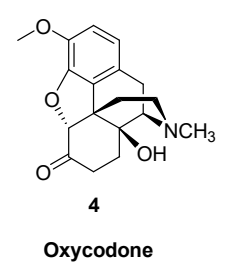

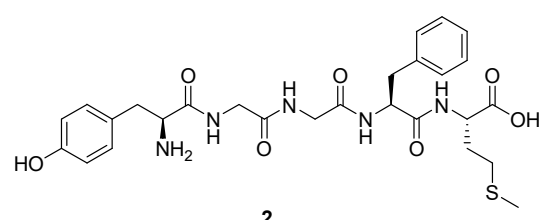

2

Met ${ }^{5}$-enkephalin

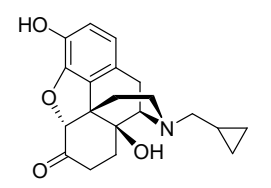

5

Naltrexone

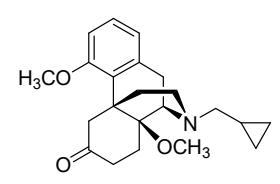

6

Cyprodime

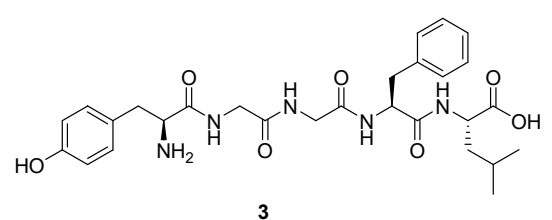

Leu ${ }^{5}$-enkephalin

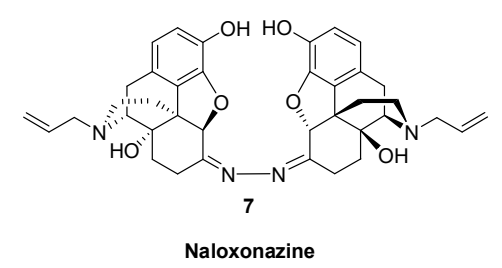

Figure 1. Chemical structures of endogenous opioid peptides and selected opioid receptor ligands.

The modern era of opioid pharmacology began with the identification of an opioid binding site in brain tissue in studies with tritiated naloxone [9]. Soon thereafter, opioid peptides were isolated from pig brain [10], which famously involved whisky as an emolument for the slaughterhouse workers. The pentapeptides Met ${ }^{5}$-enkephalin (2) and Leu ${ }^{5}$-enkephalin (3) both had morphine-like effects in inhibiting the electrically stimulated contraction of the vas deferens, with the latter compound being somewhat less potent. The enkephalins were most abundant in striatum and hypothalamus of rat, guinea pig and calf, and $\mathrm{Met}^{5}$-enkephalin (2) was generally 3-6 times more abundant than Leu ${ }^{5}$-enkephalin (3) [11,12]. An additional higher molecular weight opioid ( $\beta$-endorphin) isolated and sequenced from camel pituitary extracts proved to be a 31 amino acid polypeptide possessing homology with Met $^{5}$-enkephalin (2) [13]. A trypsin-sensitive opioid activity (dynorphin-A) isolated from pituitary is a 17 amino acid polypeptide possessing $N$-terminal homology with $\mathrm{Leu}^{5}$-enkephalin (3), with the shorter peptide dynorphin-B [1-13] having almost 1000-fold higher potency than Leu ${ }^{5}$-enkephalin (3) in the guinea pig ileum muscle preparation [14]. Soon after these discoveries, bovine DNA sequences were cloned for the $\beta$-endorphin precursor corticotropin- $\beta$-lipotropin [15], the $\operatorname{Met}^{5} / \operatorname{Leu}^{5}$-enkephalin $(2,3)$ precursor preproenkephalin-A [16] (which proved to contain four copies of Met ${ }^{5}$-enkephalin (2) and one copy of Leu ${ }^{5}$-enkephalin (3), consistent with the ratio of their tissue concentrations), and the closely related preproenkephalin-B [17]. Other researchers cloned porcine preprodynorphin, the precursor for dynorphin A [1-17], dynorphin-A [1-8], dynorphin B [1-13], and other opioid peptides [18]. 
It was soon apparent that the endogenous opioid peptides bound to at least three distinct sites in the brain and peripheral tissues, known as $\mu-, \delta-$, and $\kappa$ ORs. For a time, the orphaned $\sigma$ receptors were thought to comprise another type of OR [20], due to the analgesic (and hallucinogenic) action of pentazocine at $\kappa \mathrm{ORs}$ in brain. However, binding of $\sigma \mathrm{OR}$ ligands is not displacable by the opioid antagonist naloxone, nor do $\sigma \mathrm{ORs}$ bind opioid peptides with high affinity, such that the $\sigma$-receptor is now recognized as a pharmacological class in its own right. The $\mu \mathrm{OR}$ gene has at least 14 exons that can give rise to diverse splice variants, and at least three pharmacologically distinct subtypes are recognized: $\mu_{1}, \mu_{2}$ and $\mu_{3}$. Displacement studies in vitro and in vivo with the $\mu$-selective competitive antagonist cyprodime (6) and the $\mu_{1}$-specific competitor naloxonazine $(7)$ showed that $\left[{ }^{11} \mathrm{C}\right]$ carfentanil ([11 C]Caf, 8) binds predominantly to the $\mu_{1}$ subtype [21]. The $\mu_{3}$ subtype is alkaloid sensitive and opioid peptide insensitive; it couples to nitric oxide generation, and, extraordinarily, its endogenous agonist in amygdala seems to be morphine (1) [22]. There is also an opioid receptor-like receptor 1 (ORL1), which is activated by the 17 amino acid polypeptide known as nociceptin/ orphanin FQ (N/OFQ) [23].

Opioid signaling has an important function in the modulation of pain processing at the spinal level. ORs synthetized in the dorsal root ganglion are transported to peripheral nerve endings and to the superficial layers of the spinal cord dorsal horn. In the dorsal horn, $\mu$ ORs are the most densely expressed subtype, followed by $\delta$-, and $\kappa$ ORs. Over $70 \%$ of the ORs there are located on the central terminals of small-diameter (mostly $\mathrm{C}$ and A-delta fibres) primary afferent neurons. A main mechanism of opioid analgesia lies in the activation of presynaptic $\mu \mathrm{ORs}$ in the spinal cord, leading to decreased release of excitatory transmitters and nociceptive transmission. Unforunately, PET methods do not suffice for detecting ORs in the human spinal cord.

Figure 2 shows PET images of the distributions in human telencephalon of binding sites for the four main classes of ORs, $\mu, \delta, \kappa$, and ORL1. The pattern of $\mu$ ORs in Figure 2A encompasses the telencephalic pain pathway of limbic brain regions. Supraspinal $\mu \mathrm{ORs}$ in the nucleus accumbens and amygdala have a role in the analgesic and reinforcing properties of opioids. The thalamus, especially the medial structures, relay nociceptive spinothalamic input from the spinal cord to higher structures. $\mu$ ORs also have a prominent distribution in the brainstem, with high density in several structures associated with analgesia, such as the periaqueductal gray, rostroventral medulla, the reticular formation, and locus coeruleus [24-26]. From these structures, efferent outflow descends to the spinal cord where it acts to inhibit nociceptive transmission in afferent fibres. $\mu$ ORs are also abundant in the hypothalamus, where they might affect hormonal regulation. Receptors in the medullary vagal complex, area postrema, and nucleus tractus solitarius, can mediate endocrine actions and nausea.

As seen in Figure 2B, the $\delta$ OR has high expression in the cerebral cortex, nucleus accumbens, and the caudate putamen. This receptor is involved in analgesic activity at both spinal and supraspinal sites. Similarly as $\mu$ ORs, agonists of central $\delta$ ORs contribute to respiratory depression, whereas receptors in the gut mediate constipation, an important side effect of morphine. The $\delta$ ORs receptors localize presynaptically where they inhibit the release of excitatory neurotransmitters [27]. Despite these properties, $\delta$-selective drugs have not yet found clinical application.

The $\kappa$ ORs have wide expression in rat brain, with highest levels in the ventral tegmental area, substantia nigra, nucleus accumbens, caudate putamen, claustrum, endoperiform nucleus, various hypothalamic nuclei, and the amygdala [28]. A similar expression profile occurs in the human brain $[29,30]$, as seen in Figure 2 C. Activation of $\kappa$ ORs does not produce respiratory depression, but typical adverse effects include sedation and dysphoria, limiting the clinical use of $\kappa$ OR targeting drugs [27]. Despite generally dysphoric effects in humans, the $k \mathrm{OR}$ agonist Salvinorin- $\mathrm{A}$, which is obtained from the leaves of Salvia divinorum, finds a niche market in the drug subculture for those seeking to briefly experience a dissociative state. 

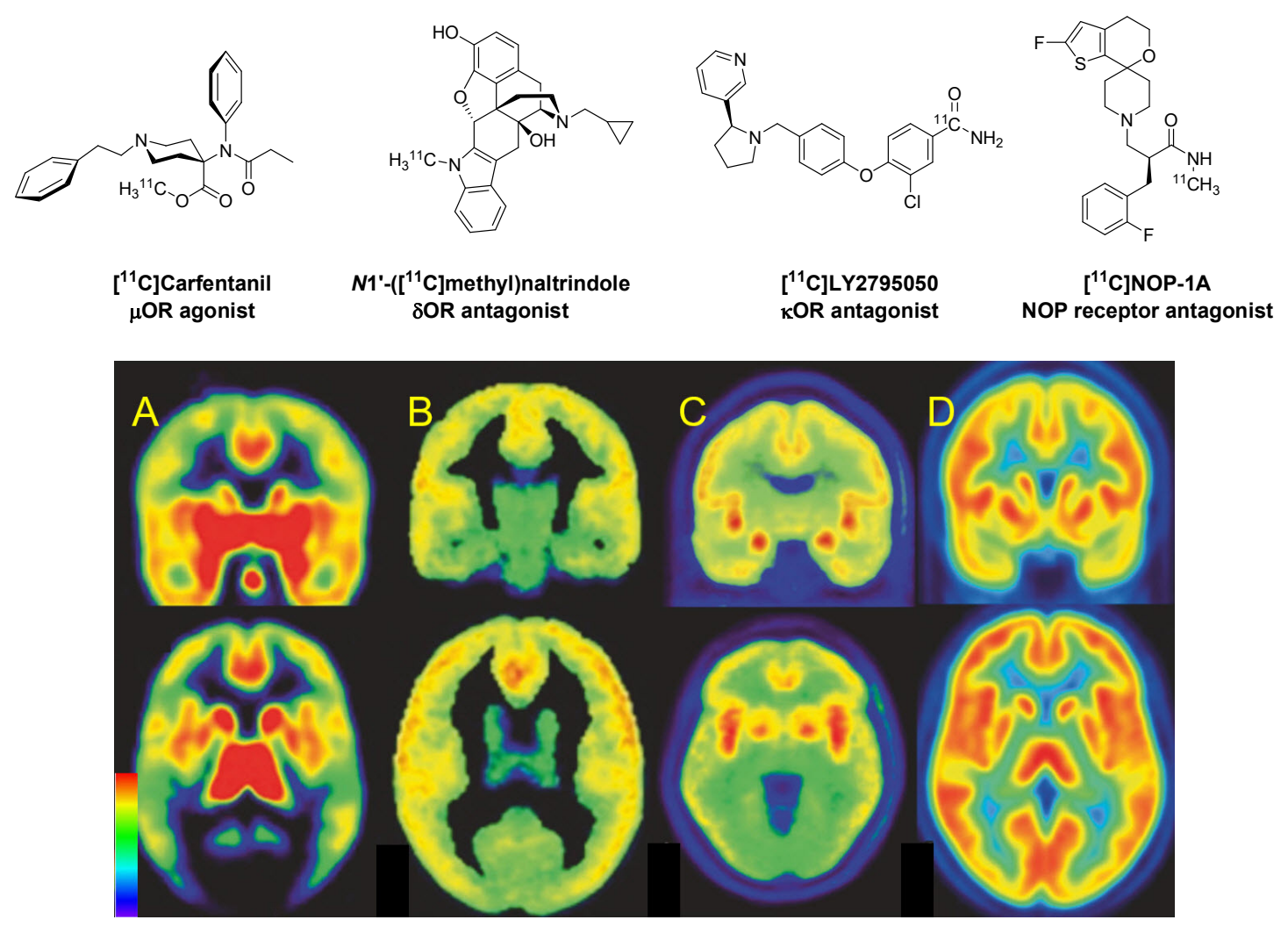

Figure 2. Human brain opioid receptor PET images in coronal (upper row) and axial (lower row) planes. Modified and reproduced with permission from Peciña et al. [19]. From left to right, we see (A) the $\mu \mathrm{OR}$ agonist $\left[{ }^{11} \mathrm{C}\right]$ carfentanil, binding most abundantly in the caudate nucleus, anterior cingulate cortex, thalamus, and pituitary gland; (B) the $\delta \mathrm{OR}$ antagonist $N 1^{\prime}-\left(\left[{ }^{11} \mathrm{C}\right]\right.$ methyl)natrindole, which has diffuse binding throughout neocortex; $(\mathbf{C})$ the $\mathrm{KOR}$ antagonist $\left[{ }^{11} \mathrm{C}\right] \mathrm{LY} 2795050$, which has high binding in the insular cortex, lateral frontal cortex and amygdala; (D) the NOP antagonist $\left[{ }^{11} \mathrm{C}\right] \mathrm{NOP}-1 \mathrm{~A}$, which binds abundantly throughout the brain. Binding sites of $\mu-, \mathrm{k}-$ and NOP-OR ligands are expressed as binding potential relative to the cerebellum $\left(\mathrm{BP}_{\mathrm{ND}}\right)$, whereas binding of the $\delta$-ligand (which has no non-binding reference region) is expressed as net influx $\left(K_{i},\right)$ in units of perfusion $\left(\mathrm{mL} \mathrm{cm}^{-3} \mathrm{~min}^{-1}\right)$. The color scale in the lower right indicates (for $\mathbf{A}, \mathbf{C}$, and $\mathbf{D}$ ) $\mathrm{BP}_{\mathrm{ND}}$ ranging from 0 to 2 , or $(\mathbf{B}) K_{i}$ ranging from $0-0.1 \mathrm{~mL} \mathrm{~cm}^{-3} \mathrm{~min}^{-1}$

Figure 2D shows a widespread and abundant expression of NOP binding sites in human brain. Agonists of the NOP receptor, unlike $\mu \mathrm{OR}$ agonists, are devoid of reinforcing or motivational properties, but are implicated in homeostatic functions such as feeding and body weight, as well as anxiety, stress, and alcohol dependence [31].

\section{Radiotracers for the PET Imaging of ORs}

\section{1. $\mu \mathrm{OR}$ Ligands and Non-Selective Ligands}

The era of OR PET imaging was preceded by a phase of studies ex vivo with tritiated ligands such as the antagonist $\left[{ }^{3} \mathrm{H}\right]$ diprenorphine $\left(\left[{ }^{3} \mathrm{H}\right] \mathrm{DPN}\right)$, which accumulated in striatum, locus coeruleus, substantia nigra pars compacta, and substantia gelatinosa of the living rat [32]. A similar pattern was revealed with the antagoninst $\left[{ }^{3} \mathrm{H}\right]$ naloxone, which showed sodium-dependent saturable binding $e x$ vivo, with a $\mathrm{B}_{\max }$ close to that seen in vitro [33]. In contrast, the agonist $\left[{ }^{3} \mathrm{H}\right]$ Foxy bound with low $\mathrm{nM}$ affinity at $\mu \mathrm{ORs}$ in vitro, but failed to accumulate in brain of living rats, a property which was attributed to the presence of high sodium in the living organism. The presence of sodium in the biding medium enhanced antagonist binding in vitro but decreases agonist binding [34]. However, addition of 
$\mathrm{Na}^{+}$to the incubation medium had little effect on the affinity of the morphiceptin analog $\mu \mathrm{OR}$ agonist Tyr-Pro-(NMe)Phe-D-Pro-NH ${ }_{2}$ in vitro ([3 $\left.\left.{ }^{3} \mathrm{H}\right] \mathrm{PL} 017\right)$ [35]. Unpredictable sensitivity of binding to the presence of sodium in the medium seems mainly to be a property of agonist ligands.

OR PET imaging began with the introduction of 3-O-acetyl- $\left[{ }^{18} \mathrm{~F}\right]$ cyclofoxy (3-O-Ac- $\left.\left[{ }^{18} \mathrm{~F}\right] \mathrm{FcyF}\right)$, (10). 3-O-Ac- $\left[{ }^{18} \mathrm{~F}\right] \mathrm{FcyF}$ (10, Figure 3) is an opioid antagonist radiotracer, which was prepared from 3-O-acetyl-6 $\alpha$-naltrexol triflate via direct nucleophilic substitution with tetraethylammonium $\left[{ }^{18} \mathrm{~F}\right]$ fluoride in anhydrous acetonitrile at $80^{\circ} \mathrm{C}$ for $15 \mathrm{~min}[36,37]$. Based on displacement studies with $\mathrm{CyF}$, binding of 3-O-Ac- $\left[{ }^{18} \mathrm{~F}\right] \mathrm{FcyF}(\mathbf{1 0})$ is likely to reveal the composite of $\mu$ - and $\mathrm{kOR}$ binding [38], despite the qualitatively $\mu \mathrm{OR}$-like binding pattern reported in living baboon brain examined with 3-O-Ac- $\left[{ }^{18} \mathrm{~F}\right] \mathrm{FcyF}(\mathbf{1 0})[36]$, and the pattern of $\left[{ }^{3} \mathrm{H}\right]$ cyclofoxy retention in rat brain analysed ex vivo [39]. However, in a rat study, the increased $\left[{ }^{3} \mathrm{H}\right]$ cyclofoxy binding provoked by chronic treatment with morphine (1) could be attributed to upregulation of $\mu \mathrm{OR}$ sites [40]. Saturation binding PET studies with $\left[{ }^{18} \mathrm{~F}\right] \mathrm{FcyF}(\mathbf{1 1})$ in awake rat indicated a single binding site with apparent affinity of $2 \mathrm{nM}$ and $\mathrm{B}_{\max }$ ranging from $15 \mathrm{pmol} / \mathrm{g}$ in white matter to $74 \mathrm{pmol} / \mathrm{g}$ in striatum; these results matched closely the corresponding results obtained in vitro [41].

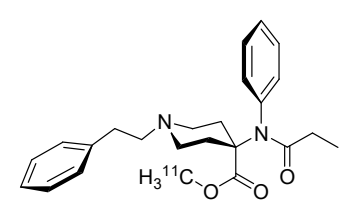

8

$\left[{ }^{11} \mathrm{C}\right] \mathrm{Caf}$
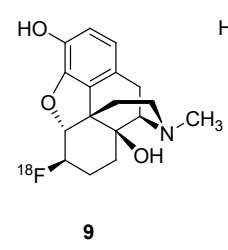

$\left[{ }^{18} \mathrm{~F}\right]$ Foxy

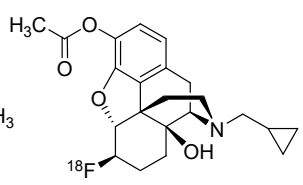

10

3-O-Ac- $\left[{ }^{18} \mathrm{~F}\right] \mathrm{FcyF}$

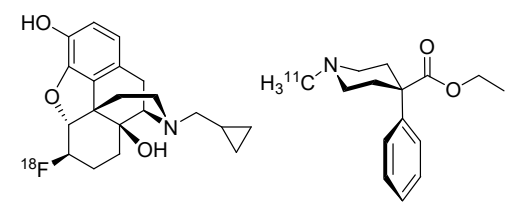

11

$\left[{ }^{18} \mathrm{~F}\right] \mathrm{FcyF}$
12

$\left[{ }^{11} \mathrm{C}\right]$ pethidine

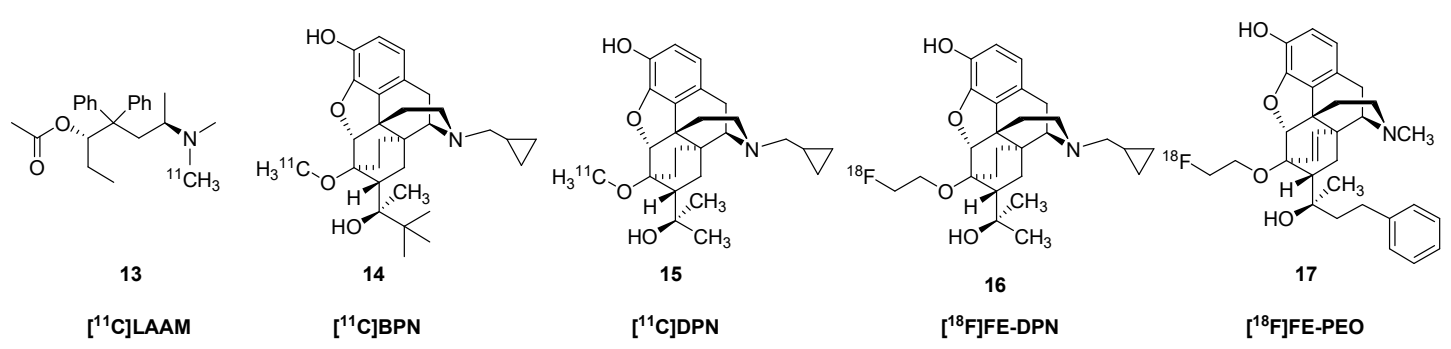

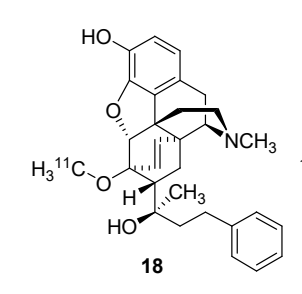

$\left[{ }^{11} \mathrm{C}\right] \mathrm{PEO}$

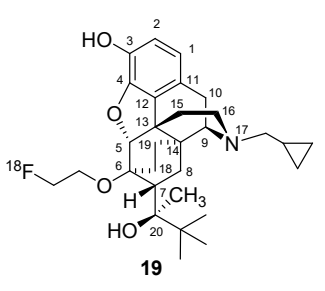

$\left[{ }^{18} \mathrm{~F}\right] \mathrm{FE}-\mathrm{BPN}$

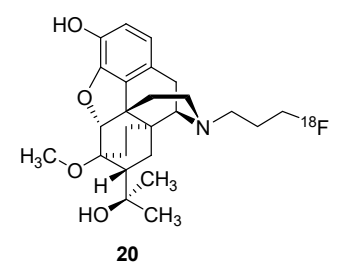

$\left[{ }^{18} \mathrm{~F}\right] \mathrm{FP}-$-norDPN

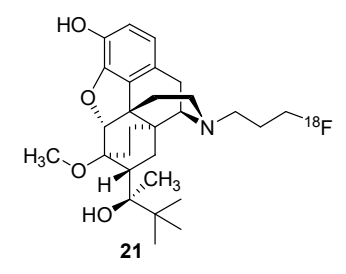

$\left[{ }^{18} \mathrm{~F}\right] \mathrm{FP}$-norBPN

Figure 3. Structures of $\mu$-selective and non-selective opioid receptor radioligands.

PET studies with $\mathrm{N}$-[methyl- $\left.{ }^{11} \mathrm{C}\right]$-labelled morphine, codeine, heroin and pethidine indicated distinct differences in uptake and kinetics in rhesus brain [42], all seemingly in relation to lipophilicity of the various drugs. A more detailed kinetics analysis of $N$-[methyl $\left.-{ }^{11} \mathrm{C}\right]$ pethidine (12) in brain of rhesus monkey indicated a very low binding potential [43]. The methadone analogue $\left[{ }^{11} \mathrm{C}\right] \mathrm{L}$ - $\alpha$-acetylmethadol $\left(\left[{ }^{11} \mathrm{C}\right] \mathrm{LAAM}, 13\right)$ had moderate uptake in brain of mice, but its specific binding was not reported [44]. These observations are a case in point supporting the generalization that effective pharmaceuticals do not necessary make good ligands for molecular imaging of their targets.

The displaceability of OR ligands by competitors in vivo is a complex matter, and one increasingly relevant given the current opioid abuse crisis in some countries. Whereas antagonists such as naloxone are effective in rescuing addicts from death by overdose, naloxone also finds experimental use in 
molecular imaging studies to confirm binding of PET tracers to ORs. Thus, the $\mathrm{BP}_{\mathrm{ND}}$ of $\left.{ }^{11} \mathrm{C}\right] \mathrm{Caf}(\mathbf{8})$ to $\mu \mathrm{ORs}$ in human brain, which ranged from 1.0 in cerebellum to 2.7 in caudate nucleus, was nearly completely displaced throughout in brain by a 50-mg dose of naltrexone (NTX, 5) [45], closely matching the dose used for resuce from opioid agonist overdose. In humans, intranasal naloxone administration caused a rapid displacement of $\left[{ }^{11} \mathrm{C}\right] \mathrm{Caf}(8)$, in accordance with the rapid response seen in treatment for overdose [46].

Buprenorphine (BPN) [47-49] is a narcotic analgesic used since the 1970s in the low dose management of post-operative pain. Since 2002, BPN has approval in the United States at higher dose or in combination with naloxone (Suboxone ${ }^{\circledR}$ ) for substitution therapy in the management of opiate addiction. BPN contains the same 6,14-ethenomorphinan skeleton as diprenorphine (DPN), and both compounds have an $N^{17}$-cyclopropylmethyl substituent, although BPN contains a tert-butyl group in position-20 instead of methyl. Interestingly, BPN has a completely different pharmacological profile than DPN. Whereas DPN is a mixed antagonist, BPN is a partial $\mu \mathrm{OR}$ agonist and $\kappa \mathrm{OR}$ antagonist, and displays some affinity for the NOP receptor [50] (Table 1).

Table 1. Binding profile of selected ligands at the human opioid receptors [51]

\begin{tabular}{|c|c|c|c|c|c|c|c|}
\hline \multirow{2}{*}{ Ligand } & \multicolumn{4}{|c|}{ Ki [nM] } & \multirow{2}{*}{ Action } & \multirow{2}{*}{$\begin{array}{l}\text { Compound } \\
\text { Class }\end{array}$} & \multirow{2}{*}{ Ref. } \\
\hline & $\mu-\mathrm{OR}$ & $\delta-\mathrm{OR}$ & K-OR & NOP & & & \\
\hline Met $^{5}$-enkephalin & 261 & 9.9 & - & - & agonist $\delta \mathrm{OR}$ & EOP & Stefanucci [52] \\
\hline Leu $^{5}$-enkephalin & 513 & 10.7 & - & - & agonist $\delta \mathrm{OR}$ & EOP & Stefanucci [52] \\
\hline$\beta$-Endorphin & 2.1 & 2.4 & 96 & - & agonist $\mu \mathrm{OR}, \mathrm{kOR}$ & EOP & Corbett [53] \\
\hline Dinorphin A & 1.6 & 1.25 & 0.05 & 386 & agonist kOR & EOP & Zhang [54] \\
\hline Nociceptin & 437 & 2846 & 147 & 0.08 & agonist & EOP & Cami-Cobeci [50] \\
\hline Morphine & 2.06 & $>10,000$ & 134 & $>10,000$ & agonist $\mu \mathrm{OR}$ & EM & Valenzano [55] \\
\hline Oxycodone & 16 & 7680 & 43,000 & - & agonist $\mu \mathrm{OR}$ & EM & Miyazaki [56] \\
\hline Naltrexone & 0.62 & 12.3 & 1.88 & - & antagonist & EM & Zheng [57] \\
\hline Carfentanil & 0.07 & - & - & - & agonist $\mu \mathrm{OR}$ & 4-AP & Henriksen [58] \\
\hline Carfentanil $^{\text {a }}$ & 0.051 & 4.7 & 13 & - & agonist $\mu \mathrm{OR}$ & 4-AP & Frost [59] \\
\hline Carfentanil ${ }^{\mathrm{b}}$ & 0.024 & 3.28 & 43.1 & - & agonist $\mu \mathrm{OR}$ & 4-AP & Cometta [60] \\
\hline Cyclofoxy $^{\mathrm{a}}$ & 2.62 & 89 & 9.3 & - & antagonist $\mu \mathrm{OR}, \mathrm{kOR}$ & EM & Rothman [38] \\
\hline DPN & 0.07 & 0.23 & 0.02 & - & antagonist & orvinol & Raynor [61] \\
\hline BPN & 1.5 & 6.1 & 2.5 & 77.4 & partial $\mu \mathrm{OR}$ agonist, $\mathrm{kOR}$ antagonist & orvinol & Cami-Cobeci [50] \\
\hline PEO & 0.18 & 5.1 & 0.12 & - & full agonist & orvinol & Marton [62] \\
\hline FE-DPN & 0.24 & 8.00 & 0.20 & - & antagonist & orvinol & Schoultz [63] \\
\hline FE-BPN & 0.24 & 2.10 & 0.12 & - & mixed agonist/antagonist & orvinol & Schoultz [63] \\
\hline FE-PEO & 0.10 & 0.49 & 0.08 & - & full agonist & orvinol & Schoultz [63] \\
\hline $\mathrm{NTI}^{\mathrm{b}}$ & 3.8 & 0.03 & 332 & - & antagonist $\delta \mathrm{OR}$ & EM & Portoghese [64] \\
\hline $\mathrm{MeNTI}^{\mathrm{b}}$ & 14 & 0.02 & 65 & - & antagonist $\delta \mathrm{OR}$ & EM & Portoghese [64] \\
\hline GR103545 & 16.2 & 536 & 0.02 & - & agonist kOR & ArAP & Schoultz [65] \\
\hline LY2459989a & 7.68 & 91.3 & 0.18 & - & antagonist $\mathrm{kOR}$ & APPB & Zheng [66] \\
\hline LY2795050 & 25.8 & 153 & 0.72 & - & antagonist KOR & APPB & Zheng [57] \\
\hline FEKAP & 7.4 & 139 & 0.43 & - & agonist kOR & ArAP & Li [67] \\
\hline EKAP & 8.6 & 386 & 0.28 & - & agonist & ArAP & $\mathrm{Li}[68]$ \\
\hline MeJDTic & 8.88 & 118 & 1.01 & - & antagonist $\mathrm{KOR}$ & JDTic & Poisnel [69] \\
\hline Salvinorin A & $>1000$ & 5790 & 1.9 & - & agonist KOR & NND & Harding [70] \\
\hline NOP-1A & - & - & - & 0.15 & antagonist NOP & FDPTP & Pike [71] \\
\hline MK-0911 & 94 & - & - & 0.6 & antagonist NOP & SPB & Hostetler [72] \\
\hline
\end{tabular}

EOP: Endogenous opioid peptide, EM: 4,5-Eopxy-morphinan, 4-AP: 4-Anilidopiperidine, orvinol: 6,14ethenomorphinan, Bentley-compound, ArAP: Arylacetamidopiperazine, APPB: Aryl-phenylpyrrolidinylmethylphenoxy-benzamide, JDTic: trans-3,4-dimethyl-4-(3-hydroxyphenyl)-piperidine, NND: "non nitrogenous" diterpene, FDPTP: $2^{\prime}$-fluoro-4', $5^{\prime}$-dihydrospiro[piperidine- 4,7'-thieno [2,3-c]pyran]- derivative, SPB: [[spiro[2.5]octan-8yl]-methyl]piperidin-4-yl] benzimidazol-2-one, ${ }^{a}$ : in the rat brain ${ }^{\mathrm{b}}$ : in guinea pig brain membranes.

Luthra et al. [73] synthesized $N^{17}$-cyclopropyl[ $\left.{ }^{11} \mathrm{C}\right]$ methyl-buprenorphine starting from $N^{17}$-nor-buprenorphine. Analogously to the $N^{17}$-cyclopropyl $\left[{ }^{11} \mathrm{C}\right]$ methyl-diprenorphine synthesis [74] the corresponding precursor, nor-BPN, was reacted with cyclopropyl[ $\left.{ }^{11} \mathrm{C}\right]$ carbonyl chloride and the carbonyl functional group of the resulting intermediate was reduced with $\mathrm{LiAlH}_{4}$. Lever et al. [75] developed a metabolically stable radiotracer, 6-O-(methyl- $\left.{ }^{11} \mathrm{C}\right)-\mathrm{BPN}$, at Johns Hopkins University in 1990 in a two-step synthesis from 3-O-TBDMS-6-O-desmethyl-BPN. The precursor was selectively alkylated in position- 6 with $\left[{ }^{11} \mathrm{C}\right]$ iodomethane/ $\mathrm{NaH}$ in $\mathrm{DMF}$ at $80{ }^{\circ} \mathrm{C}$ for two min. Following desilylation, $\left[{ }^{11} \mathrm{C}\right] \mathrm{BPN}$ (14) was produced in 10\% radiochemical yield with molar activity of $41 \mathrm{GBq} / \mu \mathrm{mol}$. Subsequently, Luthra et al. [76], aiming to avoid the formation of 3-O-alkylated by-products, introduced the base-stable, acid labile trityl protecting group to protect the phenolic hydroxyl in position-3. Applying 3-O-trityl-6-O-desmethyl-BPN in a two-step, fully-automated 
radiosynthesis $\left({ }^{11} \mathrm{C}\right.$-methylation/deprotection), yielded $\left[{ }^{11} \mathrm{C}\right] \mathrm{BPN}(\mathbf{1 4})$ in $15 \%$ radiochemical yield and with a molar activity of 13-22 GBq/ $\mu$ mol. In 2014, Schoultz et al. [63] reported a procedure for the radiosynthesis of 6-O-(2-[ $\left[{ }^{18} \mathrm{~F}\right]$ fluoroethyl)-6-O-desmethyl-BPN $\left(\left[{ }^{18} \mathrm{~F}\right] \mathrm{FE}-\mathrm{BPN}(\mathbf{1 9})\right)$ via ${ }^{18} \mathrm{~F}$-fluoroalkylation of 3-O-trityl-6-O-desmethyl-BPN (TDBPN) precursor with $\left[{ }^{18} \mathrm{~F}\right]$ fluoroethyl tosylate and subsequent trityl deprotection. The decay corrected formulated product yield was $26 \%$ and the molar activity $50-300 \mathrm{GBq} / \mu \mathrm{mol}$.

DPN, a semisynthetic thebaine/oripavine derivative with a methyl group amenable for labelling in position-20, belongs structurally to the ring-C bridged morphinans (6,14-ethenomorphinans, orvinols, Bentley-compounds) [48]. DPN is a nonselective OR antagonist with affinity in the nanomolar range (Table 1), 100 times more potent than nalorphine. Indeed, DPN is used in the veterinary medicine as an antidote/reversing agent/antagonist for remobilizing large African animals (rhinos/elephants, Revivon ${ }^{\circledR}$ ), which had been immobilized with the astonishingly potent agonists etorphine or carfentanil.

The first attempt at labelling of DPN with carbon-11 in postition-20 was reported by Burns et al. [77], who used $N$-cyclopropylmethyl-dihydronororvinone as precursor. The reaction of the precursor bearing an acetyl group in position-7-alpha with $\left[{ }^{11} \mathrm{C}\right]$ methyllithium yielded $20-\left[{ }^{11} \mathrm{C}\right]$ methyl-DPN $\left(\left[{ }^{11} \mathrm{C}\right] \mathrm{DPN}\right.$ (15)). Luthra et al. [74] developed cyclopropyl[ $\left[{ }^{11} \mathrm{C}\right]$ methyl-DPN by alkylating $N^{17}$-nor-DPN with cyclopropane $\left[{ }^{11} \mathrm{C}\right]$ carbonyl chloride and then reducing the $\mathrm{N}$-cyclopropyl $\left[{ }^{11} \mathrm{C}\right]$ carbonyl intermediate with $\mathrm{LiAlH}_{4}$ in THF. The radiochemical yield of the corresponding radioligands were low in both cases $[74,77]$.

In 1987, Lever et al. [78] developed a $\left[{ }^{11} \mathrm{C}\right] \mathrm{DPN}$ (15) synthesis by alkylating the precursor 3-O-TBDMS-6-O-desmethyl-DPN in position-6 with $\left[{ }^{11} \mathrm{C}\right]$ iodomethane in DMF containing sodium hydride at $80{ }^{\circ} \mathrm{C}$ for two min. After cleavage of the TBDMS protecting group, $\left[{ }^{11} \mathrm{C}\right] \mathrm{DPN}$ (15) was obtained with $10 \%$ radiochemical yield and $64 \mathrm{GBq} / \mu \mathrm{mol}$ molar activity. In 1994, Luthra and her associates at the Hammersmith Hospital developed a new precursor for the radiosynthesis of $\left[{ }^{11} \mathrm{C}\right] \mathrm{DPN}$ (15) [76]. Selective alkylation of 3-O-trityl-6-O-desmethyl-DPN (TDDPN) with [ $\left.{ }^{11} \mathrm{C}\right]$ iodomethane in the presence of $\mathrm{NaH} / \mathrm{DMF}\left(95^{\circ} \mathrm{C}\right.$, five min). Upon deprotection with $2 \mathrm{M}$ hydrochloric acid (95 ${ }^{\circ} \mathrm{C}$, two min) the radiotracer 15 was obtained with a radiochemical yield of $13-19 \%$ and a molar activity of 16-24 GBq/ $\mu$ mol. Recently, Fairclough et al. [79] at the University of Manchester reported a modified synthetic method also starting from TDDPN, yielding [11]DPN (15) with ten times higher molar activity ( $240 \mathrm{GBq} / \mu \mathrm{mol})$ [76] and a radiochemical yield of $32 \%$. The non-selective OR partial mixed agonist/antagonist 6-O-(methyl- $\left.{ }^{11} \mathrm{C}\right)-\mathrm{BPN}\left(\left[{ }^{11} \mathrm{C}\right] \mathrm{BPN}, 14\right)$ accumulated in striatum, thalamus and cingulate cortex in living baboon brain. Analysis of the dynamic PET data with a model assuming irreversible trapping gave a net blood-brain clearance $\left(K_{i}\right)$ of about $0.064 \mathrm{~mL} \mathrm{~cm}^{-3} \mathrm{~min}^{-1}$, which was halved by administration of naloxone, indicating substantial displaceability [80]. In a study in heroin addicts, the BPN occupancy at $\left[{ }^{11} \mathrm{C}\right] \mathrm{Caf}(8)$ binding sites was estimated relative to the drug-free baseline. An oral dose of $2 \mathrm{mg}$ BPN had an occupancy of about $50 \%$ throughout brain, whereas $16 \mathrm{mg}$ had $85 \%$ global occupancy [81]. On the other hand, therapeutic methadone (18-90 mg/day) did not provoke any discernible occupancy at 6-O-(methyl- $\left.{ }^{11} \mathrm{C}\right)$-diprenorphine $\left(\left[{ }^{11} \mathrm{C}\right] \mathrm{DPN}, 15\right)$ binding sites, neither in human opioid addicts, nor in mice, a phenomenon attributed to high agonist potency of methadone, such that withdrawl effects are averted with a rather low occupancy [82]. In further preclinical studies from the same research group, binding of $\left[{ }^{11} \mathrm{C}\right] \mathrm{DPN}(\mathbf{1 5})$ in mouse brain was unaltered by treatment with oxycodone (4) or morphine (1) (full agonists at $\mu \mathrm{ORs}$ ), but was reduced by approximately $90 \%$ by BPN (partial agonist at $\mu$ ORs and antagonist at the $\delta$ - and $\kappa \mathrm{ORs}$ ).

A comparative OR PET study in humans compared the distributions of the $\mu$ OR-selective agonist $\left[{ }^{11} \mathrm{C}\right] \mathrm{Caf}(8)$ and the mixed antagonist $\left[{ }^{11} \mathrm{C}\right] \mathrm{DPN}$ (15) [83]. Qualitatively, $\left[{ }^{11} \mathrm{C}\right] \mathrm{DPN}(\mathbf{1 5})$ binding in the striatum, cingulate and frontal cortex exceeded that of $\left[{ }^{11} \mathrm{C}\right] \mathrm{Caf}(8)$ (which had highest binding in the $\mu$ OR-rich thalamus), consistent with labeling of additional non- $\mu$ OR sites by $\left[{ }^{11} \mathrm{C}\right] \mathrm{DPN}(\mathbf{1 5})$. An investigation of ORs in human cerebellum showed abundant binding of a $\mu \mathrm{OR}$-specific ligand in the molecular layer, moderate binding of a $\mathrm{kOR}$-selective ligand, but a near absence of $\delta \mathrm{OR}$ binding sites, which was consistent with the observations of [ $\left.{ }^{11} \mathrm{C}\right] \mathrm{DPN}$ (15) binding in vivo [84]. The presence 
of binding sites in cerebellum can be an obstacle to the valid use of reference tissue methods of PET quantitation.

As a longer-lived alternative to $\left[{ }^{11} \mathrm{C}\right] \mathrm{DPN},(\mathbf{1 5})$, Wester et al. developed 6-O-(2-[ $\left[{ }^{18} \mathrm{~F}\right]$ fluoroethyl)-6-O-desmethyl-DPN $\left(\left[{ }^{18} \mathrm{~F}\right] \mathrm{FE}-\mathrm{DPN}(\mathbf{1 6})\right)$ [85], which contains a 2-fluoroethoxy group in position-6 instead of an $\mathrm{OCH}_{3}$. $\left[{ }^{18} \mathrm{~F}\right] \mathrm{FE}-\mathrm{DPN}$ (16) was synthesized from TDDPN, the so called "Luthra-precursor" [76], the same precursor as for $\left[{ }^{11} \mathrm{C}\right] \mathrm{DPN}$ (15). For the synthesis of 16, TDDPN was reacted with $\left[{ }^{18} \mathrm{~F}\right]$ fluoroethyl tosylate $\left(\left[{ }^{18} \mathrm{~F}\right] \mathrm{FE}-\mathrm{Tos}\right)$ in DMF in the presence of sodium hydride for five min at $100{ }^{\circ} \mathrm{C}$. The trityl protecting group was removed with $2 \mathrm{~N}$ hydrochloric acid, yielding $\left[{ }^{18} \mathrm{~F}\right] \mathrm{FE}-\mathrm{DPN}(\mathbf{1 6})$ with a radiochemical yield of $22 \pm 7 \%$ and the molar activity was $37 \mathrm{GBq} / \mu \mathrm{mol}$ [85]. In 2013, Schoultz et al. [86] reported an automated radiosynthesis of $\mathbf{1 6}$ from TDDPN with a decay-corrected radiochemical yield of $25 \pm 7 \%$. [ $\left.{ }^{18} \mathrm{~F}\right] \mathrm{FE}-\mathrm{DPN}$ (16) has similar uptake as $\left[{ }^{11} \mathrm{C}\right] \mathrm{DPN}(\mathbf{1 5})$ in mouse brain, and obtained a $\mathrm{BP}_{\mathrm{ND}}$ in human thalamus of about 2 relative to occipital cortex, versus only 0.3 in somatosensory cortex [87]. Women showed faster plasma metabolism $\left[{ }^{18} \mathrm{~F}\right] \mathrm{FE}-\mathrm{DPN}(\mathbf{1 6})$ than men, which might contribute to apparent gender differences in binding [88].

The first instance of full compartmental analysis of an opioid PET ligand in living brain was for the case of $\left[{ }^{11} \mathrm{C}\right] \mathrm{Caf}$, as described below. This fentanyl analogue belongs to the 4-anilidopiperidine (4AP) class of OR ligands, which are potent $\mu$ OR-selective agonists. Since 1960, numerous 4AP-type OR ligands were synthesized and their structure-activity-relationship at ORs were recently summarized $[89,90]$. Caf is structurally different from fentanyl in that it contains an additional carboxymethyl group in position- 4 of the piperidine ring. Caf is a $\mu \mathrm{OR}$-selective full agonist of extreme potency, being almost 10,000 times more potent than morphine (1) [58,91]. In 1985, [ $\left.{ }^{11} \mathrm{C}\right] \mathrm{Caf}(\mathbf{8})$ radiotracer was applied in the first human PET study $[59,92]$. For the radiosynthesis of [ $\left.{ }^{11} \mathrm{C}\right] \mathrm{Caf}$, desmethyl-Caf sodium carboxylate was alkylated with $\left[{ }^{11} \mathrm{C}\right]$ iodomethane in DMF at $35{ }^{\circ} \mathrm{C}$ for five min [92]. This procedure gave molar activity at the end of synthesis of $122 \mathrm{GBq} / \mu \mathrm{mol}$, which would correspond to mass dose of about 500 pg in a human PET study, which is too low to have any effect on particpants. According to a novel version of the radiosynthesis, desmethyl-Caf free acid serves as precursor in a reaction performed in dimethylsulfoxide with $\left[{ }^{11} \mathrm{C}\right]$ methyl triflate in the presence of tetrabutylammonium hydroxide [93]. This procedure gave a molar activity of $5 \mathrm{GBq} / \mu \mathrm{mol}$, which would correspond to a mass dose of $100 \mu \mathrm{g}$, certainly intruding into the range causing some pharmacological effects. Risk of toxicity is a serious matter in PET imaging with potent agonists, and for society in general, given the weaponization [94] (figurative and literal) that is possible with Caf.

For the compartmental analysis of $\left[{ }^{11} \mathrm{C}\right] \mathrm{Caf}(8)$, two models were fitted to dynamic time activity curves (TACs) measured by PET in human brain relative to a metabolite-corrected arterial input function [95]; this approach is the gold standard for PET quantitation. The input function obtained by HPLC analysis of plasma extracts showed that untransformed parent fractions declined to $50 \%$ at 25 min post injection. The authors estimated microparameters for the reversible transfer of the tracer across the blood-brain barrier $\left(\mathrm{K}_{1} / \mathrm{k}_{2}\right)$, the reversible binding to a receptor compartment $\left(\mathrm{k}_{3} / \mathrm{k}_{4}\right)$, and the reversible association to a non-specific compartment in brain $\left(\mathrm{k}_{5} / \mathrm{k}_{6}\right)$. The mean binding potential $\left(\mathrm{BP} ; \mathrm{k}_{3} / \mathrm{k}_{4}\right)$ was 1.8 in frontal cortex and 3.4 in thalamus at baseline, versus only 0.16 and 0.26 after treatment with naloxone $(0.1 \mathrm{mg} / \mathrm{kg})$. This study set a very high standard for quantitative PET analysis, although the molar activity of the tracer may not have been completely adequate. The amount of mass injected corresponded to about $5 \mu \mathrm{g}$ Caf per scan, which could cause some analgesia in humans, although being less than $10 \%$ of the dose causing loss of consciousness. Nonetheless, this again raises the issue of safety in PET studies with the using of high-potency full agonist ligands, as noted above. Unless the the highest possible molar activity is obtained, pharmacologically significant occupancy can occur, bringing a risk of toxicity. Test-retest studies with $\left[{ }^{11} \mathrm{C}\right] \mathrm{Caf}(8)$ showed admirable low variability $(<6 \%)$ and high intraclass correlation coefficients (ICC >0.90) of the total distribution volume $\left(\mathrm{V}_{\mathrm{T}}\right)$ relative to the metabolite-corrected arterial input, and likewise $\mathrm{BP}_{\mathrm{ND}}$ relative to a reference tissue [96].

Phenethyl-orvinol (PEO) [97] shares the same in ring-C bridged morphinan scaffold as DPN and BPN. PEO contains a 6,14-etheno-bridge, an $N^{17}$-methyl substituent and a 2-phenethyl 
group in position-20. It is a full agonist with higher affinity at $\mu \mathrm{OR}(0.18 \mathrm{nM})$ and $\kappa \mathrm{ORs}$ $(0.12 \mathrm{nM})$ than to $\delta$ ORs $(5.1 \mathrm{nM})$. The radiosynthesis of $6-\mathrm{O}$-(methyl- $\left.{ }^{11} \mathrm{C}\right)$-phenethyl-orvinol ([ $\left.\left[{ }^{11} \mathrm{C}\right] \mathrm{PEO}, 18\right)$ was reported by Marton et al. [62] in 2009. The Luthra-type trityl-protected precursor (3-O-trityl-6-O-desmethyl-phenethyl-orvinol, TDPEO) was alkylated in position-6 with $\left[{ }^{11} \mathrm{C}\right]$ iodomethane in the presence of 8-10 equiv. sodium hydride. The protecting group was removed with $1 \mathrm{M}$ hydrochloric acid in ethanol, yielding $\left[{ }^{11} \mathrm{C}\right] \mathrm{PEO}(\mathbf{1 8})$ with a radiochemical yield of $57 \pm 16 \%$ and a molar activity of $60 \mathrm{GBq} / \mu \mathrm{mol}$.

In 2012, Marton and Henriksen [98] reported the preliminary results of the synthesis of 6-O-(2- $\left[{ }^{18} \mathrm{~F}\right]$ fluoroethyl)-6-O-desmethyl-phenethyl-orvinol $\left(\left[{ }^{18} \mathrm{~F}\right] \mathrm{FE}-\mathrm{PEO}, 17\right)$ starting from 6-O-(2-tosyloxyethyl)-6-O-desmethyl-phenylethyl-orvinol (TE-TDPEO) via direct nucleophilic fluorination and subsequent deprotection. This procedure gave $\left[{ }^{18} \mathrm{~F}\right] \mathrm{FE}-\mathrm{PEO}(\mathbf{1 7})$ in an isolated preparative yield of $35 \pm 8 \%$ with a molar activity of $55-130 \mathrm{GBq} / \mu \mathrm{mol}$. In 2013 , a research group of the University of Cambridge [99] investigated $\left[{ }^{18} \mathrm{~F}\right] \mathrm{FE}-\mathrm{PEO}(\mathbf{1 7})$ as a candidate OR PET-ligand, obtained by an automated cGMP-compliant method the [ $\left.{ }^{18} \mathrm{~F}\right] \mathrm{FE}-\mathrm{PEO}$ at $28 \pm 15 \%$ yield and $52-224$ $\mathrm{GBq} / \mu \mathrm{mol}$ molar activity. In 2014, Schoultz et al. [63] reported the synthesis and biological evaluation of three structurally-related 6-O-(2-[ $\left[{ }^{18} \mathrm{~F}\right]$ fluoroethyl)-6-O-desmethy-orvinols, i.e. $\left[{ }^{18} \mathrm{~F}\right] \mathrm{FE}-\mathrm{DPN}(\mathbf{1 6})$, $\left[{ }^{18} \mathrm{~F}\right] \mathrm{FE}-\mathrm{BPN}(\mathbf{1 9})$, and $\left[{ }^{18} \mathrm{~F}\right] \mathrm{FE}-\mathrm{PEO}(\mathbf{1 7})$. The production of these ${ }^{18} \mathrm{~F}$-fluoroethyl-orvinol radiotracers $(16,17,19)$ was accomplished from 3-O-trityl-6-O-desmethyl-orvinol precursors (TDDPN, TDBPN, TDPEO) in a two-pot, three-step synthesis. $\left[{ }^{18} \mathrm{~F}\right] \mathrm{FE}-\mathrm{PEO}(\mathbf{1 7})$ had a molar activity at end of synthesis of 50-250 GBq/ $\mu \mathrm{mol}$ [99], corresponding to an injected mass $<1 \mu \mathrm{g}$ in human PET studies. The total distribution volume $\left(\mathrm{V}_{\mathrm{T}}\right)$ in rat brain ranged from $1 \mathrm{~mL} \mathrm{~cm}^{-3}$ in cerebellum to $8 \mathrm{~mL} \mathrm{~cm}^{-3}$ in thalamus; displacement studies in vitro with the $\mu \mathrm{OR}$-selective agonist DAMGO indicated high specificity in certain brain regions. $\left[{ }^{18} \mathrm{~F}\right] \mathrm{FE}-\mathrm{DPN}(\mathbf{1 6})$ had a molar activity of $37 \mathrm{GBq} / \mu \mathrm{mol}[85]$.

\subsection{Delta Ligands}

$N 1^{\prime}$-Methylnaltrindole (MeNTI, Figure 4) is a highly selective $\delta \mathrm{OR}$ antagonist (Table 1). MeNTI was prepared from naltrexone (5) in a Fischer-indol synthesis with $N$-methyl- $N$-phenylhydrazine [64]. The radiosynthesis of $\left[{ }^{11} \mathrm{C}\right] \mathrm{MeNTI}$ was reported by Lever et al. in 1995 [100]. In the first step, 3-O-benzyl-naltrindole was reacted with $\left[{ }^{11} \mathrm{C}\right]$ iodomethane in $\mathrm{DMF}$ in the presence of either sodium hydride or tetrabutylammonium hydroxide at $80^{\circ} \mathrm{C}$ for two min. The next step was hydrogenolysis of the formed 3-O-benzyl- $\mathrm{N1}^{\prime}$-(methyl- $\left.{ }^{11} \mathrm{C}\right)$-naltrindole under heterogenous catalytic conditions $\left(\mathrm{H}_{2}, 10 \%\right.$ $\mathrm{Pd} / \mathrm{C}, \mathrm{DMF} /$ ethanol, $80^{\circ} \mathrm{C}$, four min), or alternatively catalytic transfer hydrogenation $\left(\mathrm{HCOONH}_{4}\right.$, $10 \% \mathrm{Pd} / \mathrm{C}, \mathrm{MeOH})$. This gave $\left[{ }^{11} \mathrm{C}\right] \mathrm{MeNTI}(22)$ with $6 \%$ radiochemical yield and a molar activity of 76 $\mathrm{GBq} / \mu \mathrm{mol}$.
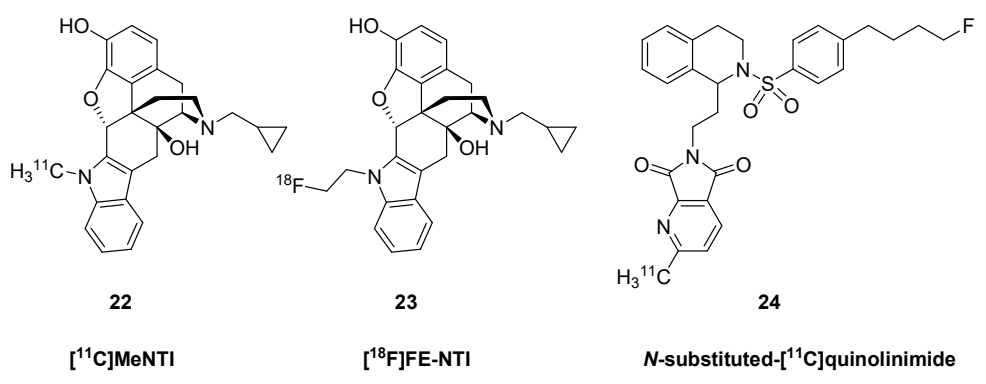

Figure 4. Labeled $\delta$-opioid receptor ligands.

Human PET studies with $\left[{ }^{11} \mathrm{C}\right]$ MeNTI (22) confirmed earlier demonstrations in living mice of $\delta$ OR-selectivity in vivo [101]. The binding ratio relative to cerebellum ranged from 1.1 in hippocampus to 1.7 in striatum and insular cortex, regional values correlated rather precisely with known density of $\delta$ ORs in vitro, and showed $50 \%$ displacement after administration of $50 \mathrm{mg}$ NTX (5). The tracer showed pseudo-irreversible binding characteristics over the course of $90 \mathrm{~min}$, with net blood-brain 
clearance $\left(K_{i}\right)$ ranging from 0.04 in cerebellum to $0.11 \mathrm{~mL} \mathrm{~cm}^{-3} \mathrm{~min}^{-1}$ in putamen [102]. The $K_{i}$ for $\left[{ }^{11} \mathrm{C}\right]$ MeNTI (22) in human brain declined by only about $20 \%$ after treatment with naloxone at a dose completely displacing $\mu \mathrm{OR}$ sites [45]. The authors of that study suggested that incomplete and variable $\delta$ OR blockade might contribute to the success of NTX (5) as a treatment for alcoholism.

$N 1^{\prime}-\left(2-\left[{ }^{18} \mathrm{~F}\right]\right.$ fluoroethyl)naltrindole $\left(23,\left[{ }^{18} \mathrm{~F}\right] \mathrm{FE}-\mathrm{NTI}, \mathrm{BU} 97001\right)$ was developed by Matthews et al. in 1999 [103]. The precursor, $N 1^{\prime}$-[2-(tosyloxyethyl)]-3-O-benzyl-naltrindole, was prepared in four consecutive transformations from naltrexone (5). In the first step, naltrexone (5) was reacted in a Fischer-indol synthesis with 2-(N1-phenylhydrazino)acetic acid ethyl ester. The resulting indolomorphinanyl-acetic ester was reacted with benzyl bromide to yield the 3-O-benzyl protected NTI derivative, which was reduced with $\mathrm{LiAlH}_{4}$ in THF-toluene to afford the corresponding indolomorphinanyl ethanol intermediate. This compound was reacted with tosyl chloride to provide the appropriate precursor with a tosyloxy leaving group. For the radiosynthesis of $\left[{ }^{18} \mathrm{~F}\right]$ FE-NTI $(23)$, the precursor was reacted in a direct nucleophilic reaction with potassium $\left[{ }^{18} \mathrm{~F}\right]$ fluoride $/ \mathrm{K}_{2} \mathrm{CO}_{3} / \mathrm{Kryptofix}[2.2 .2]$ in DMF to yield $N 1^{\prime}-\left(2-\left[{ }^{18} \mathrm{~F}\right]\right.$ fluoroethyl)-3-O-benzyl-naltrindole. Final debenzylation by hydrogenolysis under heterogenous catalytical conditions $\left(\mathrm{H}_{2}, \mathrm{Pd} / \mathrm{C}\right.$, $\mathrm{N}, \mathrm{N}$-dimethyl formamide) gave $\left[{ }^{18} \mathrm{~F}\right] \mathrm{FE}-\mathrm{NTI}(23)$ with a radiochemical yield of $10 \%$ and molar activity of $31 \mathrm{GBq} / \mu \mathrm{mol}$. $\left[{ }^{18} \mathrm{~F}\right] \mathrm{FE}-\mathrm{NTI}(\mathbf{2 3})$ was an antagonist in mouse vas deferens with high selectivity over $\mu$ - and $\mathrm{kOR}$ sites, and its tritiated version bound to rat whole brain as a single site with $\mathrm{K}_{\mathrm{D}}$ of 0.42 $\mathrm{nM}$ and $\mathrm{B}_{\max }$ of $3 \mathrm{pmol} \mathrm{g}^{-1}$ [104].

In 2007, Bourdier et al., [105] reported the radiosynthesis of a 2-[11C]methylpyrrolo[3,4-b]pyridine-5,7-dione derivative ( $N$-substituted- $\left[{ }^{11} \mathrm{C}\right]$ quinolinimide) (24). The radiotracer containing a $\left.{ }^{11} \mathrm{C}\right]$ methyl-group on the pyridine ring was synthesized from a tributylstannyl precursor, with introduction of the $\left[{ }^{11} \mathrm{C}\right]$ methyl group by the Stille reaction using $\left[{ }^{11} \mathrm{C}\right]$ iodomethane in the presence of tris(dibenzylideneacetone)dipalladium, tri-o-tolylphosphine, $\mathrm{K}_{2} \mathrm{CO}_{3}$, and $\mathrm{CuCl}$ in DMF, heated at 90 ${ }^{\circ} \mathrm{C}$ for five min. The labelled compound (24) was synthesized with a radiochemical yield of $60 \pm 10 \%$ and a molar activity of 30-56 GBq/ $\mu$ mol. The unlabelled version of the $N$-substituted quinolinimide had higher $\delta$ OR-selectivity than MeNTI, but its ${ }^{11} \mathrm{C}$-derivative (24) failed to label ORs in mouse brain, due either to excessively rapid metabolism [105], or its only moderate affinity.

\subsection{Kappa Ligands}

GR89696 (( \pm )-methyl 4[(3,4-dichlorophenyl)acetyl]-3-(1-pyrrolidinylmethyl)- 1-piperazinecarboxylate [106-108] (Glaxo Group Research Ltd.) is a kOR-selective agonist with an arylacetamidopiperazine/diacylpiperazine structural core. GR103545, the biologically active $(R)$-(-)-enantiomer of GR89696, displays subnanomolar affinity and 1000-fold selectivity for human KOR $\left(K_{i}=0.02 \mathrm{nM}\right)$, [65]. Ravert et al. [109] reported synthesis of both enantiomers of [ $\left.{ }^{11} \mathrm{C}\right] \mathrm{GR} 89696$ (26, Figure 5) from the corresponding chiral normethylcarbamoyl precursor $[108,110]$. The radiosynthesis was accomplished by acylation of the secondary amine with $\left[{ }^{11} \mathrm{C}\right]$ methyl chloroformate in dichloromethane in the presence of trimethylamine, giving product with molar radioactivity of $69 \mathrm{GBq} / \mu \mathrm{mol}$. Mouse brain distribution of the synthesized enantiomers, $\left((R)-(-)-\left[{ }^{11} \mathrm{C}\right] \mathrm{GR} 103545(25)\right.$ and the (S)-(+)-enantiomer $\left.\left[{ }^{11} \mathrm{C}\right] \mathrm{SGR}\right)$ was determined in vivo, which showed the (S)-enantiomer to be inactive. The low radiochemical yield of the radiosynthesis $(2-14 \%)[110,111]$ motivated the development of elaborate new radiochemical methods. In 2008, Schoultz et al. [112] developed a simple $\left[{ }^{11} \mathrm{C}\right]$ methyl triflate mediated methylation of carbamino adducts. Normethylcarbamoyl-GR103545 was converted to $\left[{ }^{11} \mathrm{C}\right] \mathrm{GR} 103545$ (25) with $\left[{ }^{11} \mathrm{C}_{\mathrm{CH}_{3}} \mathrm{OTf}\right.$ under mild conditions in $64-91 \%$ radiochemical yield. Wilson et al. [113] developed a method for preparing $\left[{ }^{11} \mathrm{C}\right.$-carbonyl]-methylcarbamates directly from primary or secondary amines, applying either DBU or BEMP and cyclotron-produced $\left[{ }^{11} \mathrm{C}_{\mathrm{CO}_{2}} \cdot\left[{ }^{11} \mathrm{C}\right.\right.$-carbonyl]-GR103545 (25) was synthesized with high radiochemical purity $(>98 \%)$ and molar activity of 108-162 GBq/ $\mu$ mol. In 2011, Nabulsi et al. [114] reported an automated two-step, one-pot procedure for the synthesis of $\left[{ }^{11} \mathrm{C}\right] \mathrm{GR} 103545$ (25) from normethylcarbamoyl-GR103545 via transcarboxylation using the zwitterionic carbamic complex DBU- $\mathrm{CO}_{2}$ and $\left[{ }^{11} \mathrm{C}^{-} \mathrm{CH}_{3} \mathrm{OTf}\right.$. 


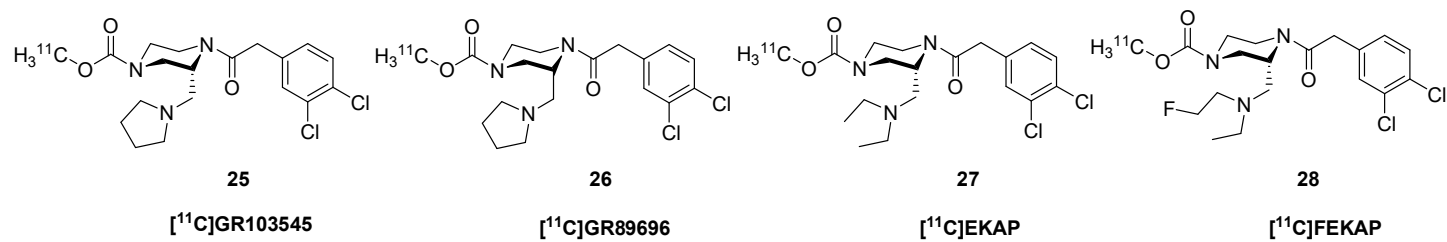

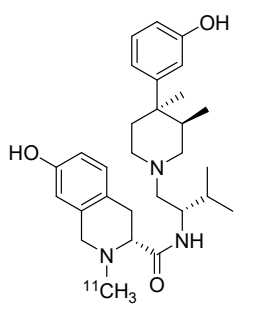<smiles>NC(=O)c1ccc(Oc2ccc(CN3CCCC3c3cccnc3)cc2)c(Cl)c1</smiles>

30

$\left[{ }^{11} \mathrm{C}\right] L Y 2795050$<smiles>NC(=O)c1ccc(Oc2ccc(CN3CCCC3c3cccnc3)cc2)c(F)c1</smiles>

31

[ $\left.{ }^{11} \mathrm{C}\right] L Y 2459989$<smiles>NC(=O)c1ccc(Oc2ccc(CN3CCCC3c3cccnc3)cc2)c(F)c1</smiles>

32 $\left[^{18} \mathrm{~F}\right] \mathrm{LY} 2459989$

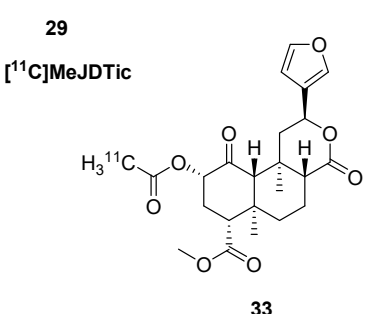

$\left[{ }^{11} \mathrm{C}\right]$ Salvinorin $\mathrm{A}$

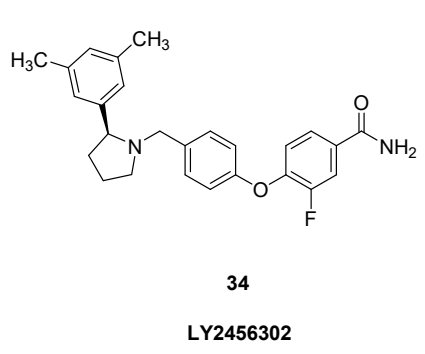

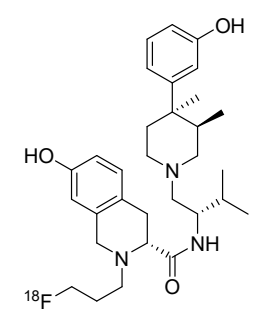

35

$\left[{ }^{18}\right.$ F $]$ FP-JDTic

Figure 5. Selected $\mathrm{KOR}$ ligands.

In PET studies, the kOR-agonist ligand $\left[{ }^{11} \mathrm{C}\right] \mathrm{GR} 103545$ (25) had a $\mathrm{V}_{\mathrm{T}}$ in baboon brain ranging from $3 \mathrm{~mL} \mathrm{~cm}^{-3}$ in cerebellum to $10 \mathrm{~mL} \mathrm{~cm}^{-3}$ in striatum and cingulate cortex [111]. Naloxone homogeneously displaced tracer throughout brain, but had no effect on $\mathrm{V}_{\mathrm{T}}$ in cerebellum, which would support use of that brain region as a reference tissue. The tracer had $>100$-fold selectivity for $\mathrm{k}$ - over $\delta$ and $\mu \mathrm{ORs}$ in vitro [65]. Much as in baboons, PET studies in rhesus monkey showed $\mathrm{V}_{\mathrm{T}}$ ranging from $8 \mathrm{~mL} \mathrm{~cm}^{-3}$ in cerebellum to $21 \mathrm{~mL} \mathrm{~cm}^{-3}$ in striatum. Other monkey studies showed $\mathrm{BP}_{\mathrm{ND}}$ ranging from 0.3 in amygdala to 2.2 in putamen [115]. This bolus plus infusion study with increasing mass dose in monkeys indicated an in vivo $\mathrm{K}_{\mathrm{D}}$ of $2 \mathrm{nM}$ and $\mathrm{B}_{\max }$ of 1-6 pmol g${ }^{-1}$. In 2014, Naganawa et al. [116] reported the first-in-human PET study with $\left[{ }^{11} \mathrm{C}\right] \mathrm{GR} 103545$ (25). Test-retest variability of the quantitative endpoint $V_{T}$ was about $15 \%$, and binding ranged from $8 \mathrm{~mL} \mathrm{~cm}^{-3}$ in cerebellum to $41 \mathrm{~mL}$ $\mathrm{cm}^{-3}$ in amygdala; Lassen plots with naltrexone blocking indicated a non-specific uptake $\left(\mathrm{V}_{\mathrm{ND}}\right)$ of only $3.4 \mathrm{~mL} \mathrm{~cm}^{-3}$, thus emphasizing the absence of any non-binding reference region.

Based on the substituted-diacylpiperazine scaffold of GR103545, researchers at Yale University developed the new KOR agonist radiotracers $\left[{ }^{11} \mathrm{C}\right]$ EKAP (27) [68] and $\left[{ }^{11} \mathrm{C}\right]$ FEKAP (28) [67] with improved pharmacological and PET-imaging profile compared with the native compound. In the open-ring analogs of GR103545, the pyrrolidinyl-methyl group of the original molecule in position-3 was replaced by a diethylamino-methyl in EKAP and a ((ethyl)2-fluoroethyl)amino)methyl group in FEKAP. Imaging studies $\left[{ }^{11} \mathrm{C}\right]$ EKAP $(27)$ in rhesus monkey showed rapid metabolism in vivo and fast, reversible binding kinetics in brain that was blockable with specific competitors. The $\mathrm{BP}_{\mathrm{ND}}$ ranged from 0.8 in frontal cortex to 1.8 in globus pallidus.

Researchers at Eli Lilly, in cooperation with the Yale University, developed $\mathrm{kOR}$ antagonist radiotracers with the 3-pyridinyl-1-pyrrolidinylmethyl structural scaffold. Along these lines, in 2013, Zheng et al. [57] synthesized the selective kOR antagonist radiotracer [ ${ }^{11}$ C]LY2795050 (30) from an iodophenyl precursor in a two-step procedure. The precursor was converted by transition metal-mediated cyanation using $\mathrm{H}^{11} \mathrm{CN}$ and $\mathrm{Pd}_{2}(\mathrm{dba})_{3} / \mathrm{dppf}$ to a $\left[{ }^{11} \mathrm{C}\right]$ nitrile intermediate. This latter was partially hydrolysed with $\mathrm{NaOH} / \mathrm{H}_{2} \mathrm{O}_{2}$ in DMF at $80{ }^{\circ} \mathrm{C}$ for five min, giving a $12 \%$ radiochemical 
yield with molar activity of $23.6 \mathrm{GBq} / \mu \mathrm{mol}$. $\left[{ }^{11} \mathrm{C}\right] \mathrm{LY} 2459989$ (31) was prepared in a two-step one-pot radiosynthesis. In the first step, an aryl-iodide-type precursor was transformed in a palladium catalyzed reaction $\left(\mathrm{Pd}_{2} \mathrm{dba}_{3} / \mathrm{dppf}\right)$ with $\mathrm{H}^{11} \mathrm{CN}$ to the corresponding $\left[{ }^{11} \mathrm{C}\right]$ nitrile, which was reacted with $\mathrm{H}_{2} \mathrm{O}_{2}$ under basic condition to afford 31 with $7.4 \%$ radiochemical yield and $23 \mathrm{GBq} / \mu \mathrm{mol}$ molar activity.

LY2459989 is the fluorine-containing analogue of LY2795050. Li et al. [117] synthesised the ${ }^{18} \mathrm{~F}$-fluorine-labelled version of LY2459989 using two different methods. Using the nitro precursor, the radiochemical yield was too low, but applying the iodonium ylide precursor, $\left[{ }^{18} \mathrm{~F}\right] \mathrm{LY} 2459989$ (30) was prepared with $36 \%$ radiochemical yield and $1,175 \mathrm{GBq} / \mu \mathrm{mol}$ molar activity. While admirably high, this molar activity falls far short of the theoretical maximium for ${ }^{18} \mathrm{~F}-$, which is $63,000 \mathrm{GBq} / \mu \mathrm{mol}$. Where does all that non-radioactive fluoride come from?

As noted above, salvinorin A [118-120] is a naturally occurring non-alkaloid neo-clerodane diterpenoid, isolated from Salvia divinorum. Also as noted above, smokings Salvinorin-A can provoke a dissociative hallucinogenic experience distinct from that of the classical hallucinogens. It has a unique structure with seven chiral carbons and is potent and highly selective $\mathrm{KOR}$ agonist; salvinorin A does not display any significant activity at other OR subtypes. In 2008, Hooker et al. [121] synthesized the carbon-11 labelled version of salvinorin A (33), using salvinorin B as precursor for the radiosynthesis. The 2-alpha-hydroxyl group of the precursor was acylated with $\left[{ }^{11} \mathrm{C}\right]$ acetyl chloride in DMF in the presence of DMAP at $0{ }^{\circ} \mathrm{C}$ for $7-10 \mathrm{~min}$, giving a radiochemical yield of $3.5-10 \%$ with molar activity

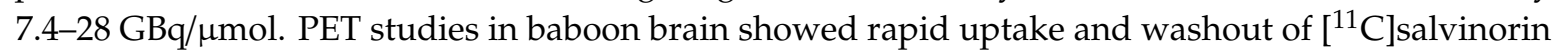
A (33), matching the brief duration of the hallucinatory/dissociative experience reported by humans users. Rat studies showed that acute doses of salvinorin A caused dose-dependent occupancy at brain KORs labelled in vivo with [ $\left.{ }^{11} \mathrm{C}\right]$ GR103545 (25). Pretreatment with a high dose in the hours before PET examination caused persistent reductions in receptor availability, despite the brief plasma half-life of the drug, and despite the rather brief duration of the hallucinogenic experience. This suggests that $\mathrm{KOR}$ activation by agonists such as salvinorin A provokes a delayed and persistent receptor internalization [122].

In 2001, Thomas et al. [123] identified the first kOR-selective antagonist ligand, trans-3,4-dimethyl-4-(3-hydroxyphenyl)piperidine (JDTic, > 200-fold selective, Table 1), with non-opiate structure. MeJDTic is a derivative of JDTic that is ring methylated on the nitrogen of the tetrahydroisoquinoline. Poisnel et al. [69] prepared $\left[{ }^{11} \mathrm{C}\right]$ MeJDTic (29) from JDTic by methylation with $\left[{ }^{11} \mathrm{C}\right]$ methyl triflate in acetonitrile at room temperature for three min. The radiochemical yield was $78-98 \%$ and the molar activity $1.5-4.4 \mathrm{GBq} / \mu \mathrm{mol}$. Recently, Schmitt et al. [124] synthesized $\mathrm{N}-\left[{ }^{18} \mathrm{~F}\right]$ fluoropropyl-JDTic ([$\left.\left.\left.{ }^{18} \mathrm{~F}\right] \mathrm{FP}-J \mathrm{DTic}\right)(35)\right)$ from JDTic with $\left[{ }^{18} \mathrm{~F}\right]$ fluoropropyl-tosylate in DMSO in the presence of DIPEA and LiI at $150{ }^{\circ} \mathrm{C}$ for $30 \mathrm{~min}$. In vivo studies in mouse showed accumulation of $\left[{ }^{18} \mathrm{~F}\right] \mathrm{FP}-J D T i c(35)$ in peripheral organs rich in $\mathrm{KORs} .\left[{ }^{11} \mathrm{C}\right] \mathrm{MeJDTic}(29)$ entered mouse brain in vivo, albeit attaining a concentration of only $0.2-0.3 \% \mathrm{ID} / \mathrm{g}$. Its binding was substantially reduced by treatment with the $\mathrm{kOR}$ agonist U50,488, but was unaffected by morphine (1) or naltrindole (NTI), thus attesting to its high selectivity for $\mathrm{KOR}$ sites [69]. The $\mathrm{KOR}$-agonist $\left[{ }^{11} \mathrm{C}\right] \mathrm{LY} 2795050$ (30) had an in vitro binding affinity of $1 \mathrm{nM}$, and 25 fold selectivity over $\mu$ ORs (Table 1). It readily entered monkey brain, and was substantially displacement by naloxone [57]. Displacement studies showed scant specific binding in monkey cerebellum, which supports its use as a reference region for quantitation. The tracer had a $\mathrm{BP}_{\mathrm{ND}}$ as high as 1.0 in parts of the basal ganglia [125]. Dual tracer studies in monkey showed the LY2795050 displaced [ $\left.{ }^{11} \mathrm{C}\right] \mathrm{Caf}(8)$ from $\mu \mathrm{OR}$ sites with an $\mathrm{ED}_{50}$ of $119 \mu \mathrm{g} / \mathrm{kg}$, whereas the $\mathrm{ED}_{50}$ at $\mathrm{kOR}$ sites was $16 \mu \mathrm{g} / \mathrm{kg}$, indicating 8-fold selectivity in vivo [125,126]. Corresponding human studies with kinetic modelling showed $\mathrm{V}_{\mathrm{T}}$ ranging from $2 \mathrm{~mL} \mathrm{~cm}^{-3}$ in cerebellum to $4 \mathrm{~mL} \mathrm{~cm}^{-3}$ in amygdala, and Lasson plots with partial NTX (5) blocking indicated a $V_{\mathrm{ND}}$ (non-specific binding) close to $1.6 \mathrm{~mL} \mathrm{~cm}^{-3}$, thus giving a $\mathrm{BP}_{\mathrm{ND}}$ of 1.5 in amygdala versus only 0.2 in cerebellum [126]. The test-retest reliability in human brain was about $10 \%$ [127]. PET with [ $\left.{ }^{11} \mathrm{C}\right] \mathrm{LY} 2795050$ (30) has revealed the dose-occupancy relationship in human brain for the experimental kOR antagonist LY2456302 (34), which is under development as a treatment of alcoholism [128]. 
$\left[{ }^{11}\right.$ C]LY2459989 (31) had sub-nM affinity at KOR sites in vitro, with 30 -fold selectivity over $\mu \mathrm{OR}$ and 400-fold selectivity over 8 OR sites [66]. Preliminary PET studies in monkey showed rapid kinetics and substantial displaceability in vivo, with $\mathrm{BP}_{\mathrm{ND}}$ ranging from 0.5 in thalamus to 2.2 in globus pallidus. A comparison of $\mathrm{KOR}$ ligands in rat showed that the agonist $\left[{ }^{11} \mathrm{C}\right] \mathrm{GR} 103545$ (25) and the antagonist $\left[{ }^{11} \mathrm{C}\right] \mathrm{LY} 2459989$ (31) had similar displacement by various KOR antagonists. However, and of great significance, the $\mathrm{KOR}$ agonists salvinorin A and U-50488, while displacing $\left[{ }^{11} \mathrm{C}\right] \mathrm{GR} 103545$ (25) binding in vivo, did not alter $\left[{ }^{11} \mathrm{C}\right] \mathrm{LY} 2459989$ (31) binding [129], which may indicate an allosteric binding mechanism. The novel $\mathrm{KOR}$ agonist tracer $\left[{ }^{11} \mathrm{C}\right]$-EKAP (27) showed fast uptake kinetics and high specific binding in monkey brain, with $V_{\mathrm{T}}$ ranging from $12 \mathrm{~mL} \mathrm{~cm}^{-3}$ in cerebellum to $\mathrm{mL} \mathrm{cm}^{-3}$ in globus pallidus, corresponding to a $\mathrm{BP}_{\mathrm{ND}}$ of 1.8 , its binding was $95 \%$ displaced by pre-blocking with the antagonists naloxone or LY2795050 [68].

The highly selective and potent $\mathrm{kOR}$-ligand U-50488 served as a scaffold for developing fluoro-alkylated PET ligands, but proved inappropriate due to 100-fold loss of affinity relative to the starting compound [130]. The novel fluorinated K-ligand [ $\left.{ }^{18} \mathrm{~F}\right] \mathrm{LY} 2459989$ (32) had similar kinetic properties in monkey PET studies to those of $\left[{ }^{11} \mathrm{C}\right] \mathrm{LY} 2459989$ (31) [117].

\subsection{Nociceptin and Opioid-like 1 Receptors (ORL1)}

Emerging evidence supports the use of agonists for the nociceptin/orphanin FQ peptide receptor (NOP) in the clinical management of pain and for substance abuse [131], thus presenting an attractive target for molecular imgaing A series of NOP ligands based on a $2^{\prime}$-fluoro- $4^{\prime}, 5^{\prime}$-dihydrospiro[piperidine-4, $7^{\prime}$-thieno[2,3-c]pyran]-scaffold were screened in rats [71]. Uptake in monkey brain in a baseline condition contrasted with a blocking condition indicated specific binding of several of the $\left[{ }^{11} \mathrm{C}\right]$-labelled compounds, of which $\left[{ }^{11} \mathrm{C}\right] \mathrm{NOP}-1 \mathrm{~A}$ ((2S)-2-[(2-fluorophenyl)methyl]- 3-(2-fluorospiro[4,5-dihydrothieno[2,3-c]pyran- 7,4' -piperidine-1' yl)- $N$-methyl-propanamide (36, Figure 6) was selected for further investigations. In the synthesis developed by Pike et al. [71], [ $\left.{ }^{11} \mathrm{C}\right] \mathrm{NOP}-1 \mathrm{~A}$ (36) was prepared from a primary-amide type precursor by methylation with $\left[{ }^{11} \mathrm{C}\right]$ iodomethane in DMSO basified with potassium hydroxide at $80{ }^{\circ} \mathrm{C}$ for 5 min. PET imaging experiments with 36 showed a $V_{\mathrm{T}}$ in monkey brain ranging from $13 \mathrm{~mL} \mathrm{~cm} \mathrm{~cm}^{-3}$ in cerebellum to $21 \mathrm{~mL} \mathrm{~cm}^{-3}$ in amygdala. This fell globally to $8 \mathrm{~mL} \mathrm{~cm}^{-3}$ after blocking with the antagonist SB-612111, indicating a $\mathrm{BP}_{\mathrm{ND}}$ of 1-2 [132]. A somewhat lower $\mathrm{V}_{\mathrm{T}}$ range was detected in human brain [133], where the test-retest reliability was about 12\% [134].

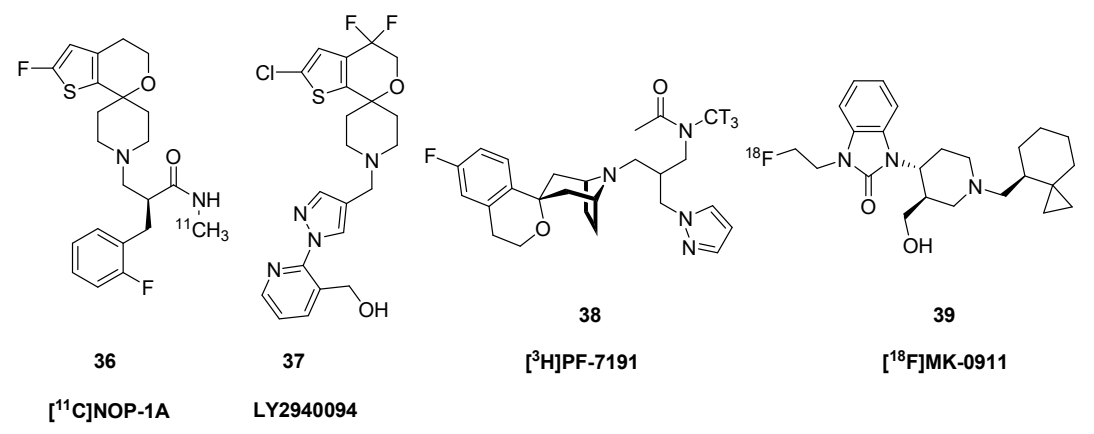

Figure 6. Chemical structures of selected ORL1 receptor ligands.

The NOP/ORL1 antagonist LY2940094 (37) exerted a dose-dependent reduction in immobility in the forced swim test, matching that provoked by imipramine, consistent with a potential antidepressant action [23]. Changes in [ $\left.{ }^{11} \mathrm{C}\right] \mathrm{NOP}-1 \mathrm{~A}$ (36) binding in brain of living rats revealed the ORL1 occupancy of orally administered LY2940094 (37) [135]. MK-0911 (1-(2-fluoroethyl)3-[(3R,4R)-3-(hydroxymethyl)-1-[[(8S)-spiro[2.5]octan-8-yl]methyl]piperidin-4-yl]benzimidazol-2- one) is a high affinity, selective NOP receptor antagonist developed by Merck Pharmaceuticals. The fluorine-18 labelled version $\left[{ }^{18} \mathrm{~F}\right] \mathrm{MK}-0911$ (39) had a $\mathrm{V}_{\mathrm{T}}$ in human brain ranging from $5 \mathrm{~mL} \mathrm{~cm}{ }^{-3}$ 
in cerebellum to $7 \mathrm{~mL} \mathrm{~cm}^{-3}$ in temporal cortex, with excellent test-retest stability [72]. Displacement studies with antagonists revealed the presence of a small specific binding component in cerebellum, again raising a red flag about reference tissue quantitation. Studies with the nociceptine ligand $\left[{ }^{3} \mathrm{H}\right] \mathrm{PF}-7191$ (38) showed sub-nM binding displacement in vitro $\left(K_{i}=0.1 \mathrm{nM}\right)$ and high selectivity over other OR types, as well as promising displaceable binding in rat brain measured ex vivo [136].

\section{Clinical Studies}

\subsection{Age and Gender}

The $\mathrm{BP}_{\mathrm{ND}}$ of $\left[{ }^{11} \mathrm{C}\right] \mathrm{Caf}(8)$ relative to occipital cortex was $20 \%$ lower in thalamus and amygdala of healthy, aged women compared with young women, but tended to increase with age in frontal cortex, whereas increases were more consistently seen in aged men [137]. This finding seems relevant to the age-dependent changes in sensitivity to $\mu \mathrm{OR}$ agonists, compounded by possible gender differences in hepatic tracer metabolism, noted above. Preliminary results with $\left[{ }^{11} \mathrm{C}\right] \mathrm{LY} 2795050$ (30) PET did not indicate any change in $\mathrm{KOR}$ availability with age in humans [138]. Another k-OR PET study with that ligand showed slightly higher $(5-10 \%) \mathrm{V}_{\mathrm{T}}$ in widespread brain regions of male subjects than that seen in age-matched women [139].

\subsection{Epilepsy}

A dual tracer PET study of patients with temporal lobe epilepsy showed increased binding of $\left[{ }^{11} \mathrm{C}\right] \mathrm{Caf}(8)$ to $\mu$ ORs in the temporal neocortex and decreased binding in the amygdala ipsilateral to the epileptic focus [140]. However, binding of $\left[{ }^{11} \mathrm{C}\right] \mathrm{DPN}$ (15) to $\mu$ - and other OR subtypes did not differ between affected and unaffected cerebral hemipsheres, emphasizing the importance of subtype selectivity in PET studies. Another multi-tracer PET study in temporal lobe epilepsy showed increased $\mu \mathrm{OR}$ binding $\left.\left({ }^{11} \mathrm{C}\right] \mathrm{Caf}(8)\right)$ in medial inferior temporal cortex and a more widespread increase in $\delta \mathrm{OR}$ binding $\left(\left[{ }^{11} \mathrm{C}\right] \mathrm{MeNTI}(\mathbf{2 2})\right)$ in the affected temporal lobe [141]. Increased $\left[{ }^{11} \mathrm{C}\right] \mathrm{DPN}(\mathbf{1 5})$ binding in temporal pole and fusiform gyrus of epilepsy patients declined with time since last seizure, indicating a transient response of the opioid system [142]. Applying a partial volume correction revealed small post-ictal increases in $\left[{ }^{11} \mathrm{C}\right] \mathrm{DPN}(\mathbf{1 5}) \mathrm{V}_{\mathrm{T}}$ in the (sclerotic) hippocampus relative to the interictal state [143], possibly indicating reduced competition from endogenous opioids. Thus, there may be reduced opioid transmission in the post-ictal period.

A study of five patients with reading epilepsy (i.e. seizures provoked by reading text) revealed very circumscribed $10 \%$ reductions in $\left[{ }^{11} \mathrm{C}\right] \mathrm{DPN}$ binding the temporal parietal cortex in the activation condition compared to non-reading baseline, whereas no such changes was seen in control subjects [144]. In the context of a competition model, the authors interpreted this to indicate task-dependent release of opioid peptides in the patients, but it is difficult to determine the causal relationship between this release and the seizures.

\subsection{Movement Disorders}

In an MPTP model of acquired parkinsonism, a substantial striatal dopamine depletion to FDOPA-PET was associated with a $20-30 \%$ reduction in the $\mathrm{V}_{\mathrm{T}}$ of $\left[{ }^{18} \mathrm{~F}\right] \mathrm{FcyF}$, (11) in opioid-receptor rich areas, i.e., caudate, anterior putamen, thalamus, and amygdala relative to intact animals [145]. These animals had recovery of their motor function, suggesting that the $\mu \mathrm{OR}$ changes were an adaptive response to dopamine depletion. The same group reported that this effect was (paradoxically) bilateral in animals with unilateral dopamine lesions [146]. In patients with Parkinson's disease, the $\left[{ }^{11} \mathrm{C}\right] \mathrm{DPN}$ (15) binding relative to occipital cortex was 20-30\% reduced in striatum and thalamus only in those patients with iatrogenic DOPA-dyskinesia, but was unaffected in nondyskinetic Parkinson's disease patients [147]. This observation seems to merit further investigation, given the disabling effect of dyskinesias often encountered in the treatment of Parkinson's disease. On the other hand, there was no 
difference in $\left[{ }^{11} \mathrm{C}\right] \mathrm{DPN}(\mathbf{1 5})$ binding in symptomatic DYT1 primary torsion dystonia patients relative to controls [148].

Regional $\left[{ }^{11} \mathrm{C}\right] \mathrm{DPN}$ (15) binding was unaffected in patients with restless legs syndrome (which, like, Parkinson's disease, is responsive to levodopa treatment). However, there was a negative correlation between $\mathrm{V}_{\mathrm{T}}$ and motor symptom severity, and a negative correlation between severity of pain and ligand binding in the medial pain system (medial thalamus, amygdala, caudate nucleus, anterior cingulate gyrus, insular and orbitofrontal cortex). The authors interpreted this result in relation to pain-induced release of endogenous peptides, rather than a primary aspect of restless legs syndrome [149].

Binding of the non-selective OR ligand $\left[{ }^{11} \mathrm{C}\right] \mathrm{DPN}$ PET was reduced by $31 \%$ in the caudate nucleus and $26 \%$ in putamen of a small group of symptomatic Huntington's disease patients compared to age-matched healthy controls [150]. This effect was less pronounced than was the loss of dopamine transporters seen in the same patients, suggesting that the reduction in ORs may partially accommodate the nigrostriatal degeneration. Despite this finding, there has been no indication for opioid medications in the symptomatic treatment of HD.

\subsection{Pain}

A qualitative study of post pontine infarct central pain showed a reduction in $\left[{ }^{11} \mathrm{C}\right] \mathrm{DPN}(\mathbf{1 5})$ uptake in the lateral cerebral cortex on the side contralateral to the main symptoms [151]. A more detailed study indicated $\left[{ }^{11} \mathrm{C}\right] \mathrm{DPN}$ (15) binding reductions in contralateral thalamus, parietal, secondary somatosensory, insular and lateral prefrontal cortices; these reductions were similar irrespective of the site of the lesion causing the central pain syndrome [152]. Indeed, this network of brain regions is recognized as comprising a central pain pathway. Another $\left[{ }^{11} \mathrm{C}\right] \mathrm{DPN}(\mathbf{1 5})$ study of central neuropathic pain showed 15-30\% lower OR-binding within the medial pain system (cingulate, insula and thalamus), as well as the inferior parietal cortex of the lateral system (Brodman area 40). Patients with peripheral neuropathic pain had bilateral and symmetrical decreases in $\left[{ }^{11} \mathrm{C}\right] \mathrm{DPN}(15)$ binding in contrast to the hemispheric changes seen in central pain patients [153]. As always, these binding reductions are ambiguous, perhaps due to reduced receptor expression, increased occupancy, or internalization.

Poor sleep quality in relation to topical application of $10 \%$ capsaicin cream (which directly activates cutaneous pain receptors) was associated with higher baseline $\left[{ }^{11} \mathrm{C}\right] \mathrm{Caf}(8) \mathrm{BP}_{\mathrm{ND}}$ in the frontal lobe [154]. Thus, we suppose that baseline cortical binding may reflect a tradeoff between pain sensitivity and some cognitive or resilience function subserved by $\mu$-ORs. Capsaicin-induced pain provoked a decrease in $\left[{ }^{11} \mathrm{C}\right] \mathrm{Caf}(8)$ binding in the contralateral thalamus by as much as $50 \%$, increasing as the subjective severity of the pain [155]. Heat pain reduced the $\left[{ }^{18} \mathrm{~F}\right] \mathrm{FE}-\mathrm{DPN}$ (16) binding in limbic and paralimbic brain areas including the rostral ACC and insula [156]. Application of sustained painful stimulus of the jaw muscle with saline injection provoked bilateral reductions in $\left[{ }^{11} \mathrm{C}\right] \mathrm{Caf}(8)$ binding in the ipsilateral amygdala (5\%) and contralateral ventrolateral thalamus (7\%) [157]. The same painful stimulus that provoked $5-10 \%$ decreases in $\left[{ }^{11} \mathrm{C}\right] \mathrm{Caf}(8)$ binding in healthy young men tended to increase binding in women; this gender difference was most pronounced in the ventral striatum ipsilateral to the pain [158]. A small group of patients with trigeminal neuralgia had reduced $\left[{ }^{11} \mathrm{C}\right] \mathrm{Caf}(8)$ binding in left nucleus accumbens, a brain region earlier implicated in pain modulation and response to reward or aversive stimuli [159]. It would be interesting to test if this phenomenon correlated with individual differences in affective state or trait neuroticism.

In another $\left[{ }^{11} \mathrm{C}\right] \mathrm{Caf}(8)$ study, the reduced binding provoked soon after administration of a sustained pain of moderate intensity had normalized in the hours after cessation of the stimulus [160]. In general, painful stimuli do not desensitize with time, so the relationship between temporal dynamics of opioid signaling and pain perception must be complex. Indeed, pain researchers and clinicians alike are familiar with the phenomenon of allodynia, which is a decrease in pain threshold, or the conversion of previously non-painful stimuli to pain. In a sciatic nerve stimulation model, pain conditioning some hours after stimulation was associated with increased C-fibre response and reduced C-fibre threshold, 
as well as supraspinal changes marked by increased binding of $\left[{ }^{11} \mathrm{C}\right] \mathrm{PEO}(\mathbf{1 8})$ in ipsilateral and bilateral structures of the rat brain [161]. Thus, allodynia may indicate inactivation of pain-mediated opioid release in brain, resulting in greater OR availability. On the other hand, an $\left[{ }^{18} \mathrm{~F}\right] \mathrm{FE}-\mathrm{DPN}$ (16) PET study in athletes contrasting receptor availability at rest with the condition immediately after running a half marathon showed reduced binding in various paralimbic and prefontal cortical structures, to an extent correlation with post-running euphoria ("runner's high") [162]. Similarly, a [ $\left.{ }^{11} \mathrm{C}\right] \mathrm{Caf}(8)$ study in recreationally active men showed a relationship between post-exercising euphoria with decreased $\mu \mathrm{OR}$ binding in widespread cortical areas after high intensity exercise, although effects were less clear after moderate intensity exercise [163].

Prolonged electrical stimulation of the motor cortex for relief of neuropathic pain caused reductions in $\left[{ }^{11} \mathrm{C}\right] \mathrm{DPN}$ (15) binding in part of the cingulate cortex, prefrontal cortex, the periaqueductal gray prefrontal cortex, and cerebellum [164]. Some of these changes correlated with the extent of pain relief. In a case study, a single session of motor cortex stimulation improved the cold pain threshold, while decreasing [ $\left.{ }^{11} \mathrm{C}\right] \mathrm{Caf}(8)$ binding in pain-network brain regions [165]. Other studies showed that low cerebral binding of $\left[{ }^{11} \mathrm{C}\right] \mathrm{DPN}(\mathbf{1 5})$ predicted for poor response to motor cortex stimulation for the treatment of neuropathic pain [166]. Stimulation of the central grey for treatment of phantom limb pain provoked a focal decrease in midbrain $\left[{ }^{11} \mathrm{C}\right] \mathrm{DPN}(\mathbf{1 5})$ binding, indicating endogenous opioid release [167].

Visceral pain applied by gastric inflammation was without effect on cerebral $\left[{ }^{11} \mathrm{C}\right] \mathrm{Caf}(8)$ binding in healthy volunteers [168], this standing in contrast to findings with somatic pain as described above. On the other hand, vestibular stimulation provoked decreased [ $\left.{ }^{18} \mathrm{~F}\right] \mathrm{FE}-\mathrm{DPN}(\mathbf{1 6})$ binding in parts of the right dominant cortical vestibular network [169].

A $\left[{ }^{11} \mathrm{C}\right]$ Caf (8) study in which painful heat was applied after administration of supposedly analgesic cream indicated a placebo-mediated reduction in receptor availability [170]. The same group later showed that placebo transcranial direct current stimulation (tDCS) reduced $\left.{ }^{11} \mathrm{C}\right] \mathrm{Caf}(8)$ $\mathrm{BP}_{\mathrm{ND}}$ in the periaqueductal gray matter (PAG), precuneus, and thalamus, indicating endogenous opioid release [171]. This placebo effect apparently increased upon administration of verum tDCS. In another study, acupuncture administered according to an authentic analgesic procedure had only slight effects on the binding of $\left[{ }^{11} \mathrm{C}\right] \mathrm{DPN}(\mathbf{1 5})$ in human brain [172]. However, a study with $\left[{ }^{11} \mathrm{C}\right] \mathrm{Caf}$ (8) showed acupuncture therapy to provoke short-term and persistent $10-30 \%$ increases in $\mu \mathrm{OR}$ binding in pain-related brain regions; importantly the verum acupuncture condition was contrasted with a sham acupuncture condition in that study [173]. Thus, while acupuncture analgesia may be "in one's head", there seems to be a real component mediated by increased opioid transmission. Transcutaneous electrical acupoint stimulation (TEAS) is an analogue of the electrical acupuncture technique. Administration of TEAS at $2 \mathrm{~Hz}$ to anesthetized monkey provoked reductions in $\left[{ }^{11} \mathrm{C}\right] \mathrm{Caf}$ (8) binding in striatum, amygdala and ACC, whereas $100 \mathrm{~Hz}$ stimulation had no effect relative to baseline PET recordings [174].

Reminiscent of the findings in the study of pain-induced sleep disturbance noted above, a cross sectional study of sensory processing in healthy volunteers showed lower baseline binding of $\left[{ }^{18} \mathrm{~F}\right]$ FE-DPN (16) in regions such as insular cortex and orbitofrontal cortex of those with greater sensitivity to cold pain. In addition, there were negative correlations between regional binding and sensory thresholds for non-painful stimuli [175]. Similarly, the individual striatal binding of $\left[{ }^{11} \mathrm{C}\right] \mathrm{Caf}(8) \mathrm{BP}_{\mathrm{ND}}$ predicted cold pressor pain threshold, but not cold pressor pain tolerance or tactile sensitivity [176]. A longitudinal [ ${ }^{18}$ F]FE-DPN (16) PET study in neuropathic pain model rats showed lower $\mu+\kappa$ OR availability in the insula, caudate putamen, and motor cortex at three months after the injury [177]. These reductions occurred in association with anhedonia (disinterest in sucrose solution). Overall, these studies suggest that individual differences in OR signaling may mediate vulnerability to environmental stressors, a topic to be elaborated in Section 3.5 below.

Binding of $\left[{ }^{11} \mathrm{C}\right] \mathrm{DPN}(\mathbf{1 5})$ was reduced in pineal gland (but not in the brain per se) of patients who had been experiencing cluster headache attacks [178], said to be one of the most painful experiences. 
The authors suggested that inputs from trigeminal nerve to the pineal gland might mediate this change. A group of seven spontaneous migrainers showed ictal reductions in $\left[{ }^{11} \mathrm{C}\right] \mathrm{Caf}(8)$ binding in the medial prefrontal cortex, which correlated with the baseline or intra-ictal binding [179]. The [ $\left.{ }^{11} \mathrm{C}\right] \mathrm{DPN}$ (15) $\mathrm{BP}_{\mathrm{ND}}$ in brain did not differ between migrainers and healthy controls, nor was there any effect of placebo treatment in either group [180].

\subsection{Personality, Drug Dependence, and Psychiatric Disorders}

Scores in the personality trait of harm avoidance in a group of 23 healthy males correlated positively with binding of $\left[{ }^{18} \mathrm{~F}\right] \mathrm{FE}-\mathrm{DPN}(\mathbf{1 6})$ in the bilateral ventral striatum, suggesting a link with predisposition to substance abuse [181]. It might follow that drug abuse is a kind of self-medication for those with pronounced harm avoidance trait. A comparison of $\left[{ }^{11} \mathrm{C}\right] \mathrm{Caf}(8)$ uptake in healthy individuals showed that high scores in the harm avoidance trait were associated with high $\mu \mathrm{OR}$ availability in frontal and insular cortex [182], again linking the hard avoidance trait with lower tonic opioid transmission. Score in a scale of behavioral activation, which conceptually guides approach behavior, and notably in a scale designated "fun-seeking", correlated positively with [ $\left.{ }^{11} \mathrm{C}\right] \mathrm{Caf}(8)$ in widespread brain regions [183]. A [ $\left.{ }^{11} \mathrm{C}\right] \mathrm{Caf}(8)$ study in 49 healthy volunteers showed an inverse relationship between $\mu \mathrm{OR}$ availability in various brain regions and individual scores in the avoidance dimension of interpersonal attachment [184]. Considering the harm avoidance findings, baseline $\mu \mathrm{OR}$ availability may mediate a trade-off between harm avoidance and avoidant behavior in interpersonal relationships, in a psychological analogue of pain or cold sensitivity.

In a large group of healthy women, $\left[{ }^{11} \mathrm{C}\right] \mathrm{Caf}(8)$ binding had a negative correlation with BOLD signal responses in amygdala, hippocampus, thalamus, and hypothalamus to viewing emotionally arousing scenes [185]. Non-sexual, albeit pleasurable social touch from a partner provoked widespread increases in $\left[{ }^{11} \mathrm{C}\right] \mathrm{Caf}(8)$ binding, suggesting reduced opioid signaling [186], whereas social laughter provoked by viewing comedic film clips decreased $\left[{ }^{11} \mathrm{C}\right] \mathrm{Caf}(8)$ binding in thalamus, caudate nucleus, and anterior insula. Furthermore, baseline $\mu \mathrm{OR}$ availability in some regions was associated with the rate of social laughter [187]. These results are difficult to reconcile, since pleasurable social experiences can seemingly have opposite effects on $\mu \mathrm{OR}$ availability. Contrasting the $\left[{ }^{11} \mathrm{C}\right] \mathrm{Caf}(8)$ binding in euthymic and unhappy states (provoked by autobiographical reflection) in young women showed higher $\mu \mathrm{OR}$ availability in the rostral anterior cingulate, ventral pallidum, amygdala, and inferior temporal cortex in the unhappy state [188]. This kind of sad reflection provoked greater increases in [ $\left.{ }^{11} \mathrm{C}\right] \mathrm{Caf}(\mathbf{8})$ binding in widespread brain regions of women with major depression [189], suggesting an exaggerated opioid response in relation to mood disorder, as distinct from ordinary sadness. A pilot PET study with the kOR-ligand [ $\left.{ }^{11} \mathrm{C}\right] \mathrm{GR} 103545$ (25) did not reveal any binding differences between healthy control and patients suffering from major depression [190]. However, a [ ${ }^{11}$ C]EKAP (27) kOR study in healthy volunteers showed an inverse correlation between social status and $\left[{ }^{11} \mathrm{C}\right]$ salvinorin $\mathrm{A}$ (33) binding in widespread brain areas, with a special association occurring in brain regions mediating reward or aversion [191]. Given the association between social stress and depression, one might have expected covariance $\mathrm{KOR}$ in the two studies.

A recent $\left[{ }^{11} \mathrm{C}\right] \mathrm{Caf}(8)$ PET study of 19 schizophrenia patients and 20 controls showed a $10 \%$ lower (Cohen's $d=0.7$ ) $\mu \mathrm{OR}$-availability in striatium of the patient group. While such a decrease can hardly be pathogonomic of disease, the authors also reported considerably higher inter-regional covariance of the $\left[{ }^{11} \mathrm{C}\right] \mathrm{Caf}(8)$ binding in the patients, which might indicate an aberent spatial pattern of opioid signalling in schizophrenia [192]. There have been no OR PET studies in bipolar disorder.

$\mathrm{A}\left[{ }^{11} \mathrm{C}\right] \mathrm{Caf}(8)$ study showed that circulating levels of the anti-nociceptive cytokine IL-1ra (which correlated with neuroticism scores) predicted for the pain response to a standard stimulus (saline infusion to the masseter muscle), and likewise the reduction in $\mu \mathrm{OR}$ availability in the basal ganglia during the painful stimulus [193]. In a group of female patients suffering from fibromyalgia, $\left[{ }^{11} \mathrm{C}\right] \mathrm{Caf}$ (8) binding correlated with pain-evoked BOLD signal changes in several brain regions, including dorsolateral prefrontal cortex and nucleus accumbens [194]. Overall, these studies suggest some 
linking between opioid transmission, mood, and inflammatory markers, which returns to the the notioin that OR signaling may mediate personality traits and vulnerability to stresses of various sorts.

$\left.{ }^{11} \mathrm{C}\right] \mathrm{Caf}(8)$ PET showed persistently increased $\mu \mathrm{OR}$ binding in frontal and cingulate cortex of acutely detoxified cocaine addicts, which correlated with the extent of craving [195]. Elevated [ $\left.{ }^{11} \mathrm{C}\right] \mathrm{Caf}$ (8) binding in frontal and temporal cortical regions was a significant predictor of time to relapse to cocaine use among abstinent addicts [196]. Binge cocaine users showed a significant association between $\left[{ }^{11} \mathrm{C}\right.$ ]GR103545 (25) binding to kORs with the amount of drug consumed. Furthermore, a three-day cocaine binge reduced binding by about 15\% [197]. The cerebral binding $\left(\mathrm{V}_{\mathrm{T}}\right)$ of the ORL1 ligand [ $\left.{ }^{11} \mathrm{C}\right]$ NOP-1A (36) was globally elevated 10\% in detoxified cocaine users [198].

One $\left[{ }^{11} \mathrm{C}\right] \mathrm{Caf}(8)$ PET study showed persistently increased $\mu \mathrm{OR}$ binding in striatum of detoxified alcoholics, which furthermore correlated with the extent of craving [199]. Abstinent alcoholics showed significantly higher $\left[{ }^{11} \mathrm{C}\right] \mathrm{Caf}(8)$ binding compared to controls, but a blunting of the response to amphetamine (which indirectly displaces $\mu$ OR binding), resembling that seen by the same research group in compulsive gamblers [200]. However, others saw only a small increase in [ $\left.{ }^{11} \mathrm{C}\right] \mathrm{DPN}(\mathbf{1 5}) \mathrm{V}_{\mathrm{T}}$ in brain of acutely withdrawn alcoholics, although there was a correlation between individual PET results and craving scores at the time of scanning [201]; the combined $(\mu+\kappa)$ PET signal in that study makes difficult a comparison with $\left[{ }^{11} \mathrm{C}\right] \mathrm{Caf}(8)$ studies. Post mortem autoradiographic examination of $\left[{ }^{3} \mathrm{H}\right]$ DAMGO binding in brain of a large group of alcoholics showed substantial reductions in $\mu \mathrm{OR}$ binding sites, whereas low $\left[{ }^{11} \mathrm{C}\right] \mathrm{Caf}(8) \mathrm{BP}_{\mathrm{ND}}$ in ventral striatum of acutely detoxified patients predicted high risk of relapse and poor response to naloxone in interaction with the $\mu$ OR rs1799971 allele [202]. The disagreement between $\mu \mathrm{OR}$ findings in vivo and post mortem could indicate low tonic occupancy in alcohol dependent patients, since competition effects would disappear in autoradiographic studies.

In a [ $\left.{ }^{11} \mathrm{C}\right]$ MeNTI (22) PET study, there was globally $10-20 \%$ higher $\delta$ OR binding in brain of a large group of alcohol-dependent subjects; which reached significance upon correcting for age, gender, and smoking status; there was an inverse relationship between binding in some regions and intensity of craving [203]. The $\mathrm{V}_{\mathrm{T}}$ of the $\mathrm{kOR}$-selective ligand [ ${ }^{11} \mathrm{C}$ ]LY2795050 (30) was significantly lower in amygdala and pallidum of alcohol-dependent subjects [138]. This stands in contrast to the usual finding of increased $\mu \mathrm{OR}$ binding and the single report of elevated $\delta \mathrm{OR}$ binding.

The naloxone challenge paradigm has a long history in investigations of the regulation of the neuroendocrine axis, but it has been uncertain if naloxone-induced increases in ACTH and cortisol secretion bear any relation to central OR pathways. In a [ $\left.{ }^{11} \mathrm{C}\right] \mathrm{Caf}(8)$ PET study of healthy volunteers there were negative relationships between cortisol (but not ACTH) response to naloxone and ligand $\mathrm{BP}_{\mathrm{ND}}$ in ventral striatum, putamen and caudate [204]. The inverse relationship between naloxone-induced cortisol secretion and $\left[{ }^{11} \mathrm{C}\right] \mathrm{Caf}(8) \mathrm{BP}_{\mathrm{ND}}$ in various brain regions of healthy volunteers was absent in alcohol dependent subjects [205]. This suggests that central ORs exert a top-down regulation of the neuroendocrine axis, which might contribute to individual differences in stress response, and that the normal regulation of this axis is disprupted in alcohol dependence.

There was only a slight difference in $\left[{ }^{11} \mathrm{C}\right] \mathrm{Caf}(8)$ binding between non-smoking carriers of the $\mu$ OR rs1799971 allelic variants, but this allelic difference was greater among smokers. Furthermore, the contrast in PET results between active and denicotinized cigarette conditions revealed a positive relationship between reward and altered $\mu \mathrm{OR}$ availability in the smokers [206]. An apparent re-analysis of the same data showed widespread reductions in $\left[{ }^{11} \mathrm{C}\right] \mathrm{Caf}(8)$ binding after smoking a nicotine-containing cigarette; this effect was moderated by the rs1799971 polymorphism, where carriers of the A allele showed greater response to active cigarette smoking, and higher baseline $\mu \mathrm{OR}$ binding [207]. The authors conceded that non-nicotinergic factors, i.e. conditioning, could be contributing to aspects of smoking related opioid transmission [208].

Smoking subjects with higher dependence, craving, and cigarette consumption rates showed lower baseline $\left[{ }^{11} \mathrm{C}\right] \mathrm{Caf}(8) \mathrm{BP}_{\mathrm{ND}}$ in limbic brain regions. There was bluniting of this association during NTX (5) treatment [209], but there was very low residual specific binding in the NTX condition, which must have compromised the sensitivity of the method. Another $\left[{ }^{11} \mathrm{C}\right] \mathrm{Caf}(8)$ PET study showed no 
difference in $\mathrm{BP}_{\mathrm{ND}}$ between placebo and active nicotine cigarette conditions, and no difference between smokers and nonsmokers. However, there was a negative correlation in the smokers between $\mathrm{BP}_{\mathrm{ND}}$ in bilateral superior temporal cortex with scores in an index of nicotine dependence [210].

As noted above, challenge with amphetamine can indirectly provoke increased opioid peptide release. However, in a placebo-controlled, double-blinded and randomized [ $\left.{ }^{11} \mathrm{C}\right] \mathrm{Caf}(8)$ PET study, amphetamine challenge $(0.3 \mathrm{mg} / \mathrm{kg})$ did not alter $\mu \mathrm{OR}$ availability in healthy male volunteers [211]. This stands in contrast to another study, wherein a high dose of amphetamine $(0.5 \mathrm{mg} / \mathrm{kg})$ provoked reductions in $\left[{ }^{11} \mathrm{C}\right] \mathrm{Caf}(8)$ binding in widespread brain regions, i.e. frontal cortex, putamen, caudate, thalamus, anterior cingulate, and insula, whereas a sub-pharmacological dose was without such an effect $[212,213]$. Preclinical studies point to the importance of receptor internalization on the vulnerability of OR-receptor binding to challenge with amphetamine [214]. Notwithstanding this caveat, amphetamine induced reductions in $\left[{ }^{11} \mathrm{C}\right] \mathrm{Caf}(8)$ binding were blunted in compulsive gamblers compared to that in a healthy control group controlled for smoking and drinking [215]. There was a general correlation between dopamine synthesis capacity to FDOPA PET and $\left[{ }^{11} \mathrm{C}\right] \mathrm{Caf}(8)$ binding in putamen of healthy controls, and likewise in pathological gamblers, consistent with a tight relationship between dopamine and opioid systems in relation to compulsive behaviors [216].

Women with bulimia nervosa had reduced $\left[{ }^{11} \mathrm{C}\right] \mathrm{Caf}(8)$ binding in the left insula, to an extent correlating with their duration of fasting [217]. Obese patients (BMI 40) had globally $20 \%$ lower $\left[{ }^{11} \mathrm{C}\right] \mathrm{Caf}(8) \mathrm{BP}_{\mathrm{ND}}$ compared to lean volunteers; contrary to some reports, the same obese subjects had normal dopamine $\mathrm{D}_{2}$ receptor levels in striatum [218]. There were similar reductions in $\left.{ }^{11} \mathrm{C}\right] \mathrm{Caf}(8)$ binding in morbidly obese subjects and patients with binge eating disorder [219]. Weight loss after bariatric surgery for the treatment of obesity resulted in a global $25 \%$ increase of $\mu$ OR binding [220]. A dual tracer study with $\left[{ }^{11} \mathrm{C}\right] \mathrm{Caf}(8)$ and the dopamine receptor ligand $\left[{ }^{11} \mathrm{C}\right]$ raclopride showed a high correlation in the striatum of lean subjects, whereas this correlation was considerably weaker in the ventral (limbic) striatum of the morbidly obese, suggesting an uncoupling of opioid/dopamine interactions in that condition [221]. This finding might predict analogous results in gambling and substance abuse disorders, which likewise may involve dysregulation opioid/dopamine interactions.

Feeding, regardless of the hedonic experience (palatable versus unpalatable meal), provoked widespread decreases in $\left[{ }^{11} \mathrm{C}\right] \mathrm{Caf}(8)$ binding in non-obese healthy subjects, suggesting that OR transmission mediates some aspect of the rewarding properties of food [222]. Also in non-obese subjects, $\left.{ }^{[1} \mathrm{C}\right] \mathrm{Caf}(8) \mathrm{BP}_{\mathrm{ND}}$ in amygdala correlated inversely with $\mathrm{BMI}$ in the range 20-27 [223]. In that study, $\mathrm{BP}_{\mathrm{ND}}$ in other brain regions correlated with the BOLD signal response in orbitofrontal cortex upon viewing palatable food. In a group of lean subjects, the $\left[{ }^{11} \mathrm{C}\right] \mathrm{Caf}(8) \mathrm{BP}_{\mathrm{ND}}$ at baseline in widespread brain regions correlated with BOLD responses to viewing palatable food [224], suggesting that low basal occupancy increases the response to cues. Interestingly, exercise increased or decreased thalamic $\mu \mathrm{OR}$ binding in these subjects; the direction of this change correlated with the individual BOLD signal in the contrast between viewing palatable and non-palatable food. This draws attention to individual differences in effects of exercise on the hedonic response to food, which may have some bearing on the relationship between exercise and weight loss, with the caveat that only intense exercise may significantly engage opioid transmission, as claimed above. Other studies show widespread reductions in $\mu \mathrm{OR}$ availability in frontolimbic regions after high intensity aerobic exercise, in correlation with negative affect. In contrast, mean binding was unaltered after moderate-intensity exercise, although there was some positive association with euphoria [225]; too much of a good thing spoils runner's high, it seems.

\section{Conclusions and Outlook}

The past decades have seen extraordinary progress in the development of ligands for PET studies of ORs. Early radiopharmaceutical research focused on studies with the antagonist $\left.{ }^{11} \mathrm{C}\right] \mathrm{DPN}$ (15) and the $\mu \mathrm{OR}$-selective agonist $\left[{ }^{11} \mathrm{C}\right] \mathrm{Caf}(\mathbf{8})$, and the great preponderance of human PET studies have employed these and closely related tracers. While studies with non-selective tracers reveal the 
composite of OR binding sites, specific tracers may be more indicative of physiological changes in disease states. Attaining high molar activity is of great importance in PET studies with $\left[{ }^{11} \mathrm{C}\right] \mathrm{Caf}(8)$ and other highly potent agonist ligands; fortunately, most tracers described in this review have molar activities of at least $50 \mathrm{GBq} / \mu \mathrm{mol}$, corresponding to an injected mass of about $1 \mu \mathrm{g}$ of the drug. This is hardly a relevant dose in the case of antagonist ligands, and would give a comfortable 100-fold margin of safety with the potent $\mu \mathrm{OR}$ agonist $\left[{ }^{11} \mathrm{C}\right] \mathrm{Caf}(\mathbf{8})$.

The $\mu \mathrm{OR}$ ligands have the useful property of binding in competition with endogenous opioid peptides, such that changes in the uptake in PET studies can reveal altered endogenous opioid release under various physiological conditions. This model has been particularly useful in studies of pain pathways, which largely involve $\mu \mathrm{ORs}$ in telencephalon, and in some pharmacological or behavioral activation studies. However, the simple competition model may be inadequate to account for all observations. Thus, one of the $\left[{ }^{11} \mathrm{C}\right] \mathrm{Caf}(8)$ studies noted above reports widespread reductions in $\mu \mathrm{OR}$ availability after smoking [207], despite the 30-3000-fold lower affinity of endogenous opioid peptides at $\mu \mathrm{OR}$. This would seem to imply an implausibly enormous increase in peptide release to effect such changes by competition alone.

Pain studies have so far dominated the field of clinical PET research with OR-ligands, with relatively few reports on other models or conditions, as summarized in Table 2. For example, there in only one PET study of opioid receptors in schizophrenia, and only scant documentation in depression, or for that matter, in a range of common neurological disorders. In several human diseases noted above, the OR binding may be only $10 \%$ higher or lower than in the control group; while these small differences can have a large effect size, it is perhaps difficult to argue that such small differences can be causative of complex disorders or symptoms.

Table 2. A summary of the key results with opioid PET in clinical research.

\begin{tabular}{|c|c|c|c|}
\hline Condition & Ligand & Main Finding & Ref. \\
\hline Healthy aging & $\begin{array}{l}{\left[{ }^{11} \mathrm{C}\right] \mathrm{Caf}(8)} \\
(\mu \mathrm{OR})\end{array}$ & $20 \%$ decrease in frontal cortex (females) & [137] \\
\hline Epilepsy & $\begin{array}{l}{\left[{ }^{11} \mathrm{C}\right] \mathrm{Caf}(8)} \\
(\mu \mathrm{OR})\end{array}$ & Increased in ipsilateral temporal lobe, decreased in amygdala & [140] \\
\hline Epilepsy & $\begin{array}{l}{\left[{ }^{11} \mathrm{C}\right] \mathrm{DPN}(\mathbf{1 5})} \\
\text { (mixed ligand) }\end{array}$ & No change & [140] \\
\hline Parkinson's disease & $\begin{array}{l}{\left[{ }^{11} \mathrm{C}\right] \mathrm{DPN}(\mathbf{1 5})} \\
\text { (mixed ligand) }\end{array}$ & $\begin{array}{l}20-30 \% \text { decrease in striatum and thalamus only in those } \\
\text { patients with iatrogenic DOPA-dyskinesia }\end{array}$ & [147] \\
\hline Pontine infarct central pain & $\begin{array}{l}{\left[{ }^{11} \mathrm{C}\right] \mathrm{DPN}(\mathbf{1 5})} \\
\text { (mixed ligand) }\end{array}$ & Reduced throughout pain network & [151] \\
\hline Capsaicin-induced acute pain & $\begin{array}{l}{\left[{ }^{11} \mathrm{C}\right] \mathrm{Caf}(8)} \\
(\mu \mathrm{OR})\end{array}$ & $\begin{array}{l}\text { Up to } 50 \% \text { decrease contralateral thalamus, in proportion to } \\
\text { subjective severity }\end{array}$ & [155] \\
\hline $\begin{array}{l}\text { Sustained painful stimulus of the jaw } \\
\text { muscle with saline injection }\end{array}$ & $\begin{array}{l}{\left[{ }^{11} \mathrm{C}\right] \mathrm{Caf}(8)} \\
(\mu \mathrm{OR})\end{array}$ & $\begin{array}{l}\text { Blateral decrease in binding in the ipsilateral amygdala (5\%) } \\
\text { and contralateral ventro-lateral thalamus }(7 \%)\end{array}$ & [157] \\
\hline Harm avoidance trait in healthy males & $\begin{array}{l}{\left[{ }^{18} \mathrm{~F}\right] \mathrm{FE}-\mathrm{DPN}(\mathbf{1 6}) \text { (mixed }} \\
\text { ligand) }\end{array}$ & $\begin{array}{l}\text { Trait correlated positively with binding in vental striatum, } \\
\text { suggesting link with substance abuse }\end{array}$ & [181] \\
\hline $\begin{array}{l}\text { Correlation with BOLD signal responses } \\
\text { A large group of healthy women, binding. } \\
\text { to viewing emotionally arousing scenes }\end{array}$ & $\begin{array}{l}{\left[{ }^{11} \mathrm{C}\right] \mathrm{Caf}(8)} \\
(\mu \mathrm{OR})\end{array}$ & $\begin{array}{l}\text { Negative correlation in amygdala, hippocampus, thalamus, } \\
\text { and hypothalamus }\end{array}$ & [185] \\
\hline Major depressive disorder & $\begin{array}{l}{\left[{ }^{11} \mathrm{C}\right] \mathrm{GR} 103545(25)} \\
(\mathrm{KOR})\end{array}$ & No difference from controls & [190] \\
\hline Detoxified cocaine addicts & {$\left[{ }^{11} \mathrm{C}\right] \mathrm{Caf}(8)(\mu \mathrm{OR})$} & $\begin{array}{l}\text { Increased in frontal and cingulate cortex, which correlated } \\
\text { with the extent of craving }\end{array}$ & [195] \\
\hline Detoxified alcohol-dependent subjects & {$\left[{ }^{11} \mathrm{C}\right] \mathrm{MeNTI}(\mathbf{2 2})$ (סOR) } & $\begin{array}{l}\text { Globally } 10-20 \% \text { increased binding inverse relationship in } \\
\text { some regions with intensity of craving }\end{array}$ & [203] \\
\hline Obesity (BMI > 40) & $\begin{array}{l}{\left[{ }^{11} \mathrm{C}\right] \mathrm{Caf}(8)} \\
(\mu \mathrm{OR})\end{array}$ & Globally $20 \%$ lower compared to lean volunteers & [218] \\
\hline
\end{tabular}

Addiction research using PET studies of ORs are so far mostly confined to alcohol, cocaine, and nicotine abuse and (strangely, perhaps), opioid addiction has hardly been a research theme, other than in 
a few occupancy studies. Since antagonists are relatively safe at doses provoking high occupancy (viz 50 mg naloxone for opioid overdose), we suppose that the $B_{\max }$ of ORs might be determinable in relation to opioid addiction and withdrawal by conducting serial PET studies over a range of molar activity, even in the presence of significant agonist occupancy. Indeed, chronic morphine was reported 45 years ago to increase the abundance of $\left[{ }^{3} \mathrm{H}\right]$ naloxone binding sites in rat brain [226], but no such studies are reported in human opioid users, despite the catastrophe of the current opioid addiction epidemic. This kind of information might help to understand better the correlates of addiction and relapse. In addition, genetic studies of dopaminergic and opioid systems in relation to addiction [227], in conjunction with molecular imaging studies, could help to establish better the risk factors for opioid addiction. Endomorphins and other novel opioid petpides may present new avenues for obtaining opioid analgesia [228], while moderating the risk of "iatrogenic opioid addiction". The development of PET tracers with good binding properties in vivo and high selectivity for ORs other than the $\mu$-type has accelerated in the past decade. However, there remain relatively few clinical molecular imaging studies of these important targets. Thus, developments in radioligand chemistry have for the presence to read for the present presence outpaced clinical PET imaging, a state of affairs that could enable and motivate a broad range of studies focusing on non- $\mu$ ORs over the coming decades. Just for example, $\mathrm{kORs}$ have an established role in the reinstatement of stress induced drug use in experimental animals, i.e. nicotine use [229], and very recent results indicate a relationship between $\mathrm{kORs}$ and stress-induced binge cocaine use [197].

Funding: This research received no external funding.

Conflicts of Interest: The authors declare no conflict of interest.

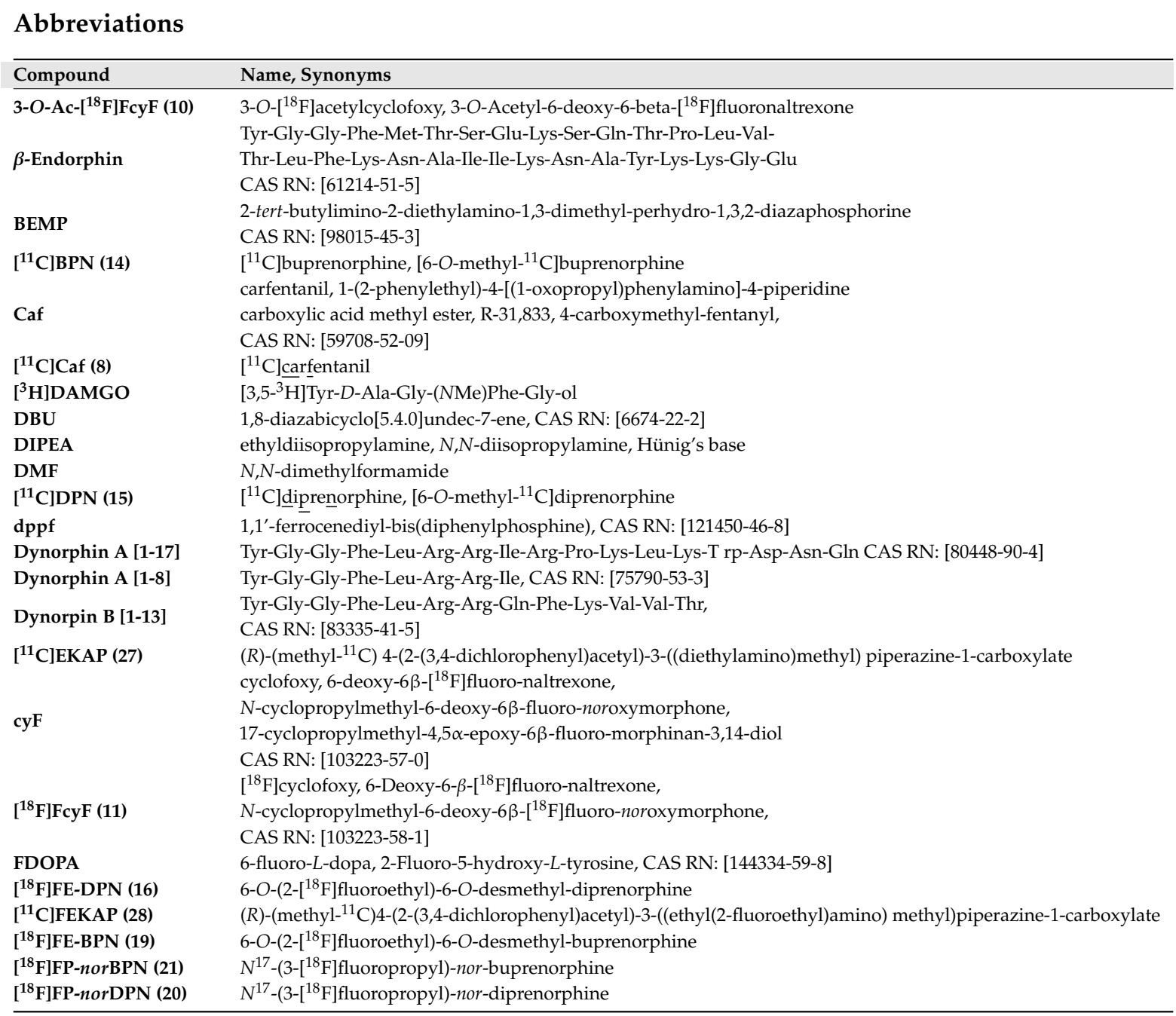




\begin{tabular}{|c|c|}
\hline$\left[{ }^{18}\right.$ F]FE-NTI (23) & {$\left[{ }^{18} \mathrm{~F}\right]$ fluoroethyl-naltrindole, $N 1^{\prime}-\left(2-\left[{ }^{18} \mathrm{~F}\right] \mathrm{Fluoroethyl}\right)$-naltrindole, $\left[{ }^{18} \mathrm{~F}\right] \mathrm{BU} 97001$} \\
\hline$\left[{ }^{18}\right.$ F]FE-PEO (17) & $6-\mathrm{O}-\left(2-\left[{ }^{18} \mathrm{~F}\right]\right.$ fluoroethyl $)-6-\mathrm{O}-$ desmethyl-phenethyl-orvinol \\
\hline$\left[{ }^{18}\right.$ F]FE-Tos & {$\left[{ }^{18} \mathrm{~F}\right]$ fluoroethyl tosylate } \\
\hline Foxy & $\begin{array}{l}\text { 6-deoxy-6 } \beta \text {-fluoro-oxymorphone, «fluorooxymorphone », 4,5 } \alpha \text {-Epoxy -6 } \beta \text {-fluoro-17-methyl-morphinan-3,14-diol, } \\
\text { CAS RN: [92593-44-7] }\end{array}$ \\
\hline$\left[{ }^{3} \mathrm{H}\right] \mathrm{Foxy}$ & $\begin{array}{l}{\left[1,2-{ }^{3} \mathrm{H}\right]-4,5 \alpha \text {-epoxy-6 } 6 \text {-fluoro-17-methyl-morphinan-3,14-diol, }} \\
\text { CAS RN: }[96917-45-2]\end{array}$ \\
\hline$\left[{ }^{11} \mathrm{C}\right] \mathrm{GR} 103545(25)$ & [(3,4-dichlorophenyl)acetyl]-(3R)-(1-pyrrolidinylmethyl)-1-piperazine carboxylic acid methyl ${ }^{-11} \mathrm{C}$ ester \\
\hline$\left[{ }^{11} \mathrm{C}\right] \mathrm{GR} 89696$ (26) & 4-[(3,4-dichlorophenyl)acetyl]-3-( $R, S)$-(1-pyrrolidinylmethyl)-1-piperazine carboxylic acid methyl- ${ }^{11} C$ ester \\
\hline HD & Huntington's disease \\
\hline$\left[{ }^{11}\right.$ C]LAAM (13) & $\begin{array}{l}\left.\left.N \text {-(methyl- }{ }^{11} \mathrm{C}\right)-\mathrm{L}-\alpha \text {-acetoxymethadol, } N \text {-(methyl- }{ }^{11} \mathrm{C} \text { )-levo-alpha-acetyl methadol, } \mathrm{N} \text {-(methyl- }{ }^{11} \mathrm{C}\right) \text {-levomethadyl } \\
\text { acetate }\end{array}$ \\
\hline Leu ${ }^{5}$-enkephalin & H-Tyr-Gly-Gly-Phe-Leu-OH, CAS RN: [58569-55-4] \\
\hline LY2459989 & 3-fluoro-4-[4-[[(2S)-2-(3-pyridyl)pyrrolidin-1-yl]methyl]phenoxy] benzamide \\
\hline LY2795050 & $\begin{array}{l}\text { 3-chloro-4-[4-[[(2S)-2-(3-pyridyl)pyrrolidin-1-yl]methyl]phenoxy] benzamide, } \\
\text { CAS RN: [1346133-08-1] }\end{array}$ \\
\hline LY2456302 (34) & $\begin{array}{l}\text { (S)-4-(4-((2-(3,5-dimethylphenyl)pyrrolidin-1-yl)methyl)phenoxy)-3-fluorobenzamide, CERC-501, CAS RN: } \\
\text { [1174130-61-0] }\end{array}$ \\
\hline LY2940094 & $\begin{array}{l}\text { ([2-[4-[(2-chloro-4,4-difluoro-spiro[5H-thieno[2,3-c]pyran-7,4'-piperidine]- } \\
1^{\prime} \text {-yl)methyl]-3-methyl-pyrazol-1-yl]-3-pyridyl]methanol), BTRX-246040, } \\
\text { CAS RN: [1307245-86-0] }\end{array}$ \\
\hline Met ${ }^{5}$-enkephalin & H-Tyr-Gly-Gly-Phe-Met-OH \\
\hline$\left[{ }^{11} \mathrm{C}\right]$ MeJDTic (29) & $\begin{array}{l}\text { (3S)-7-hydroxy- } N-((1 S)-1-[[3 R, 4 R)-4-(3-h y d r o x y p h e n y l)-3,4-\text { dimethyl- } \\
\text { 1-piperidinyl]methyl]-2-methylpropyl)-2-[11 C]methyl-1,2,3,4-tetrahydro- } \\
\text { 3-isoquinolinecarboxamide }\end{array}$ \\
\hline$\left[{ }^{11} \mathrm{C}\right] \mathrm{MeNTI}(22)$ & {$\left[{ }^{11} \mathrm{C}\right]$ methyl-naltrindole, $N 1^{\prime}-\left[{ }^{11} \mathrm{C}\right]$ methyl-naltrindole } \\
\hline$\left[{ }^{18}\right.$ F]MK-0911 (39) & $\begin{array}{l}\text { 1-(2-[18}\left[{ }^{18}\right] \text { fluoroethyl)-3-[(3R,4R)-3-(hydroxymethyl)-1-[[(8S)-spiro[2.5]octan-8-yl] } \\
\text { methyl]piperidin-4-yl]benzimidazol-2-one }\end{array}$ \\
\hline MPTP & 1-methyl-4-phenyl-1,2,3,6-tetrahydropyridine, CAS RN: [28289-54-5] \\
\hline Oxycodone & $\begin{array}{l}\text { 14-hydroxy-dihydrocodeinone, CAS RN: [76-42-6] } \\
N^{17} \text {-allyl-14-hydroxy-dihydromorphinone, } N^{17} \text {-Allyl-noroxymorphone, }\end{array}$ \\
\hline Naloxone & $\begin{array}{l}\text { CAS RN: [465-65-6] } \\
N^{17} \text {-cyclopropylmethyl-14-hydroxy-dihydromorphinone, }\end{array}$ \\
\hline Naltrexone & $\begin{array}{l}N^{17} \text {-cyclopropylmethyl-noroxymorphone, NTX } \\
\text { CAS RN: [16590-41-3] }\end{array}$ \\
\hline Nociceptine & Phe-Gly-Gly-Phe-Thr-Gly-Ala-Arg-Lys-Ser-Ala-Arg-Lys-Leu-Ala-Asn-Gln \\
\hline $\begin{array}{l}N \text {-substituted- } \\
{\left[{ }^{11} \text { C]quinolinimide (24) }\right.}\end{array}$ & $\begin{array}{l}\text { 6-(2-\{2-[4-(4-fluorobutyl)-benzenesulfonyl]-1,2,3,4-tetrahydro-isoquinolin-1-yl\} } \\
\text {-ethyl)-2-[11 C]methyl-pyrrolo[3,4-b]pyridine-5,7-dione }\end{array}$ \\
\hline NTI & naltrexone-indole, naltrindole, CAS RN: [111555-53-4] \\
\hline$\left[{ }^{11} \mathrm{C}\right] \mathrm{NOP}-1 \mathrm{~A}(36)$ & $\begin{array}{l}\text { (2S)-2-[(2-fluorophenyl)methyl]-3-(2-fluorospiro[4,5-dihydro-thieno[2,3-c]pyran- } \\
\left.\text { 7,4'-piperidine]-1'-yl)-N-[ }{ }^{11} \mathrm{C}\right] \text { methyl-propanamide }\end{array}$ \\
\hline OR & opioid receptor \\
\hline$\left[{ }^{11} \mathrm{C}\right]$ PEO (18) & $\left[{ }^{11} \mathrm{C}\right]$ phenethyl-orvinol, [6-O-methyl $\left.-{ }^{11} \mathrm{C}\right]$ phenethyl-orvinol \\
\hline PET & positron emission tomography \\
\hline $\mathbf{P d}_{2} \mathrm{dba}_{3}$ & $\mathrm{Pd}_{2}(\mathrm{dba})_{3}$, tris(dibenzylideneacetone)dipalladium, CAS RN: [51364-51-3] \\
\hline$\left[{ }^{3} \mathrm{H}\right] \mathrm{PL} 017$ & $\begin{array}{l}{\left[3,5-{ }^{3} \mathrm{H}\right] \mathrm{Tyr}-\text { Pro-(NMe)Phe-D-Pro-NH }} \\
2,3-\mathrm{N}-\mathrm{Me}-\mathrm{Phe}-\left[{ }^{3} \mathrm{H}\right] \text { morphiceptin, } \\
{\left[{ }^{3} \mathrm{H}\right]\left[\mathrm{MePhe}^{3} \text {,D-Pro }\right] \text { morphiceptin }}\end{array}$ \\
\hline Salvinorin A & $\begin{array}{l}\text { methyl }(2 S, 4 a R, 6 a R, 7 R, 9 S, 10 a S, 10 b R) \text {-9-acetyloxy-2-(furan-3-yl)-6a,10b-dimethyl- } \\
\text { 4,10-dioxo-2,4a,5,6,7,8,9,10a-octahydro-1H-benzo[f]isochromene-7-carboxylate, CAS RN: [83729-01-5] }\end{array}$ \\
\hline TBDMS & tert-butyldimethylsilyl protecting group \\
\hline TDBPN & $\begin{array}{l}\text { 3-O-trityl-6-O-desmethyl-buprenorphine, CAS RN: [157891-93-5] } \\
\text { 3-O-trityl-6-O-desmethyl-diprenorphine, CAS RN: [157891-92-4], }\end{array}$ \\
\hline TDDPN & $\begin{array}{l}\text { "Luthra-precursor", TDDPN was the first product of the company ABX advanced biochemical compounds } \\
\text { Biomedizinische Forschungsreagenzien GmbH, Radeberg in } 1997\end{array}$ \\
\hline TDPEO & 3-O-trityl-6-O-desmethyl-phenethyl-orvionol, CAS RN: [1187551-69-4] \\
\hline U-50488 & $\begin{array}{l}\text { 3,4-dichloro- } N \text {-methyl- } N-[(1 R, 2 R)-2-(1-\text { pyrrolidinyl)cyclohexyl]- benzene acetamide, NIH10533, CAS RN: } \\
\text { [67198-13-4] }\end{array}$ \\
\hline
\end{tabular}

\section{References}

1. Gulland, J.M.; Robinson, R. Constitution of codeine and thebaine. Mem. Proc. Manchester Lit. Phil. Soc. 1925, 69-86, 79-86.

2. Gates, M.; Tschudi, G. The synthesis of morphine. J. Am. Chem. Soc. 1952, 74, 1109-1110.

3. Gates, M.; Tschudi, G. The synthesis of morphine. J. Am. Chem. Soc. 1956, 78, 1380-1393. [CrossRef] 
4. Bentley, K.W.; Cardwell, H.M.E. The Morphine-Thebaine group of alkaloids. Part V. The absolute stereochemistry of the morphine, benzylisoquinoline, aporphine, and tetrahydroberberine alkaloids. J. Chem. Soc. 1955, 3252-3260. [CrossRef]

5. Rice, K.C. Synthetic opium alkaloids and derivatives. A short total synthesis of ( \pm )-dihydrothebainone, $( \pm)$-dihydrocodeinone, and ( \pm )-nordihydrocodeinone as an approach to a practical synthesis of morphine, codeine, and congeners. J. Org. Chem. 1980, 45, 3135-3137. [CrossRef]

6. Lever, J.R. PET and SPECT imaging of the opioid system: Receptors, radioligands and avenues for drug discovery and development. Curr. Pharm. Des. 2007, 13, 33-49. [CrossRef] [PubMed]

7. Henriksen, G.; Willoch, F. Imaging of opioid receptors in the central nervous system. Brain 2008, 131, 1171-1196.

8. Dannals, R.F. Positron emission tomography radioligands for the opioid system. J. Label. Compd. Radiopharm. 2013, 56, 187-195. [CrossRef]

9. Pert, C.B.; Snyder, S.H. Properties of opiate-receptor binding in rat brain. Proc. Natl. Acad. Sci. USA 1973, 70, 2243-2247. [CrossRef]

10. Hughes, J.; Smith, T.W.; Kosterlitz, H.W.; Fothergill, L.A.; Morgan, B.A.; Morris, H.R. Identification of two related pentapeptides from the brain with potent opiate agonist activity. Nature 1975, 258, 577-579. [CrossRef]

11. Di Giulio, A.M.; Majane, E.M.; Yang, H.Y. On the distribution of [met $\left.{ }^{5}\right]$ - and $\left[\mathrm{leu}^{5}\right]$-enkephalins in the brain of the rat, guinea-pig and calf. Br. J. Pharmacol. 1979, 66, 297-301. [CrossRef] [PubMed]

12. Hughes, J.; Kosterlitz, H.W.; Smith, T.W. The distribution of methionine-enkephalin and leucine-enkephalin in the brain and peripheral tissues. Br. J. Pharmacol. 1977, 61, 639-647. [CrossRef] [PubMed]

13. Li, C.H.; Chung, D. Isolation and Structure of an Untriakontapeptide with Opiate Activity from Camel Pituitary Glands. Proc. Natl. Acad. Sci. USA 1976, 73, 1145-1148. [CrossRef] [PubMed]

14. Goldstein, A.; Tachibana, S.; Lowney, L.I.; Hunkapiller, M.; Hood, L. Dynorphin-(1-13), an extraordinarily potent opioid peptide. Proc. Natl. Acad. Sci. USA 1979, 76, 6666-6670. [CrossRef] [PubMed]

15. Nakanishi, S.; Inoue, A.; Kita, T.; Numa, S.; Chang, A.C.; Cohen, S.N.; Nunberg, J.; Schimke, T.R. Construction of bacterial plasmids that contain the nucleotide sequence for bovine corticotropin-beta-lipotropin precursor. Proc. Natl. Acad. Sci. USA 1978, 75, 6021-6025. [CrossRef]

16. Noda, M.; Furutani, Y.; Takahashi, H.; Toyosato, M.; Hirose, T.; Inayama, S.; Nakanishi, S.; Numa, S. Cloning and sequence analysis of cDNA for bovine adrenal preproenkephalin. Nature 1982, 295, 202-206. [CrossRef]

17. Horikawa, S.; Takai, T.; Toyosato, M.; Takahashi, H.; Noda, M.; Kakidani, H.; Kubo, T.; Hirose, T.; Inayama, S.; Hayashida, H.; et al. Isolation and structural organization of the human preproenkephalin B gene. Nature 1983, 306, 611-614. [CrossRef]

18. Kakidani, H.; Furutani, Y.; Takahashi, H.; Noda, M.; Morimoto, Y.; Hirose, T.; Asai, M.; Inayama, S.; Nakanishi, S.; Numa, S. Cloning and sequence analysis of cDNA for porcine $\beta$-neo-endorphin/dynorphin precursor. Nature 1982, 298, 245-249. [CrossRef]

19. Peciña, M.; Karp, J.F.; Mathew, S.; Todtenkopf, M.S.; Ehrich, E.W.; Zubieta, J.-K. Endogenous opioid system dysregulation in depression: Implications for new therapeutic approaches. Mol. Psychiatry 2019, 24, 576-587. [CrossRef]

20. Su, T.P. Evidence for sigma opioid receptor: Binding of $\left[{ }^{3} \mathrm{H}\right] \mathrm{SKF}-10047$ to etorphine-inaccessible sites in guinea-pig brain. J. Pharmacol. Exp. Ther. 1982, 223, 284-290.

21. Eriksson, O.; Antoni, G. $\left[{ }^{11} \mathrm{C}\right]$ Carfentanil binds preferentially to mu-opioid receptor subtype 1 compared to subtype 2. Mol. Imaging 2015, 14, 476-483. [CrossRef] [PubMed]

22. Zhu, W.; Ma, Y.; Bell, A.; Esch, T.; Guarna, M.; Bilfinger, T.V.; Bianchi, E.; Stefano, G.B. Presence of morphine in rat amygdala: Evidence for the $\mathrm{mu}_{3}$ opiate receptor subtype via nitric oxide release in limbic structures. Med. Sci. Monit. 2004, 10, 433-439.

23. Witkin, J.M.; Rorick-Kehn, L.M.; Benvenga, M.J.; Adams, B.L.; Gleason, S.D.; Knitowski, K.M.; Li, X.; Chaney, S.; Falcone, J.F.; Smith, J.W.; et al. Preclinical findings predicting efficacy and side-effect profile of LY2940094, an antagonist of nociceptin receptors. Pharma Res. Per. 2016, 4, e00275. [CrossRef] [PubMed]

24. Janson, W.; Stein, C. Peripheral opioid analgesia. Curr. Pharm. Biotechnol. 2003, 4, 270-274. [CrossRef] [PubMed]

25. Mansour, A.; Fox, C.A.; Akil, H.; Watson, S.J. Opioid-receptor mRNA expression in the rat CNS: Anatomical and functional implications. Trends Neurosci. 1995, 18, 22-29. [CrossRef] 
26. Atweh, S.F.; Kuhar, M.J. Distribution and physiological significance of opioid receptors in the brain. Br. Med. Bull. 1983, 39, 47-52. [CrossRef]

27. Benyhe, S.; Zádor, F.; Ötvös, F. Biochemistry of opioid (morphine) receptors: Binding, structure and molecular modelling. Acta Biol. Szeged 2015, 59 (Suppl. 1), 17-37.

28. Meng, F.; Xie, G.X.; Thompson, R.C.; Mansour, A.; Goldstein, A.; Watson, S.J.; Akil, H. Cloning and pharmacological characterization of a rat kappa opioid receptor. Proc. Natl. Acad. Sci. USA 1993, 90, 9954-9958. [CrossRef]

29. Simonin, F.; Gavériaux-Ruff, C.; Befort, K.; Matthes, H.; Lannes, B.; Micheletti, G.; Mattéi, M.G.; Charron, G.; Bloch, B.; Kieffer, B. kappa-Opioid receptor in humans: cDNA and genomic cloning, chromosomal assignment, functional expression, pharmacology, and expression pattern in the central nervous system. Proc. Natl. Acad. Sci. USA 1995, 92, 7006-7010. [CrossRef]

30. Zhu, J.; Chen, C.; Xue, J.-C.; Kunapuli, S.; DeRiel, J.K.; Liu-Chen, L.-Y. Cloning of a human kappa opioid receptor from the brain. Life Sci. 1995, 56, 201-207. [CrossRef]

31. Witkin, J.M.; Statnick, M.A.; Rorick-Kehn, L.M.; Pintar, J.E.; Ansonoff, M.; Chen, Y.; Tucker, R.C.; Ciccocioppo, R. The biology of Nociceptin/Orphanin FQ (N/OFQ) related to obesity, stress, anxiety, mood, and drug dependence. Pharmacol. Ther. 2014, 141, 283-299. [CrossRef] [PubMed]

32. Pert, C.B.; Kuhar, M.J.; Snyder, S.H. Autoradiograhic localization of the opiate receptor in rat brain. Life Sci. 1975, 16, 1849-1853. [CrossRef]

33. Pert, C.B.; Snyder, S.H. Identification of opiate receptor binding in intact animals. Life Sci. 1975, 16, 1623-1634. [CrossRef]

34. Hu, X.; Wang, Y.; Hunkele, A.; Provasi, D.; Pasternak, G.W.; Filizola, M. Kinetic and thermodynamic insights into sodium ion translocation through the $\mu$-opioid receptor from molecular dynamics and machine learning analysis. PLoS Comput. Biol. 2019, 15, e1006689. [CrossRef] [PubMed]

35. Blanchard, S.G.; Lee, P.H.; Pugh, W.W.; Hong, J.S.; Chang, K.J. Characterization of the binding of a morphine (mu) receptor-specific ligand: Tyr-Pro-NMePhe-D-Pro-NH ${ }_{2},\left[{ }^{3} \mathrm{H}\right]-\mathrm{PL} 17$. Mol. Pharmacol. 1987, 31, 326-333.

36. Pert, C.B.; Danks, J.A.; Channing, M.A.; Eckelman, W.C.; Larson, S.M.; Bennett, J.M.; Burke, T.R.J.; Rice, K.C. 3-[ $\left.{ }^{18} \mathrm{~F}\right]$ Acetylcyclofoxy: A useful probe for the visualization of opiate receptors in living animals. FEBS Lett. 1984, 177, 281-286. [CrossRef]

37. Larson, S.M.; Di Chiro, G. Comparative anatomo-functional imaging of two neuroreceptors and glucose metabolism: A PET study performed in the living baboon. J. Comput. Assist. Tomogr. 1985, 9, 676-681. [CrossRef]

38. Rothman, R.B.; Bykov, V.; Reid, A.; De Costa, B.R.; Newman, A.H.; Jacobson, A.E.; Rice, K.C. A brief study of the selectivity of norbinaltorphimine, (-)-cyclofoxy, and (+)-cyclofoxy among opioid receptor subtypes in vitro. Neuropeptides 1988, 12, 181-187. [CrossRef]

39. Ostrowski, N.L.; Burke, T.R.J.; Rice, K.C.; Pert, A.; Pert, C.B. The pattern of $\left[{ }^{3} \mathrm{H}\right]$ cyclofoxy retention in rat brain after in vivo injection corresponds to the in vitro opiate receptor distribution. Brain Res. 1987, 402, 275-286. [CrossRef]

40. Rothman, R.; McLean, S.; Bykov, V.; Lessor, R.A.; Jacobson, A.E.; Rice, K.C.; Holaday, J.W. Chronic morphine upregulates a mu-opiate binding site labeled by $\left[{ }^{3} \mathrm{H}\right]$ cycloFOXY: A novel opiate antagonist suitable for positron emission tomography. Eur. J. Pharmacol. 1987, 142, 73-81. [CrossRef]

41. Kawai, R.; Carson, R.E.; Dunn, B.; Newman, A.H.; Rice, K.C.; Blasberg, R.G. Regional brain measurement of Bmax and KD with the opiate antagonist cyclofoxy: Equilibrium studies in the conscious rat. J. Cereb. Blood Flow. Metab. 1991, 11, 529-544. [CrossRef] [PubMed]

42. Hartvig, P.; Bergström, K.; Lindberg, B.; Lundberg, P.O.; Lundqvist, H.; Långström, B.; Svärd, H.; Rane, A. Kinetics of ${ }^{11} \mathrm{C}$-labeled opiates in the brain of rhesus monkeys. J. Pharmacol. Exp. Ther. 1984, 230, 250-255. [PubMed]

43. Hartvig, P.; Eckernäs, S.A.; Lindberg, B.S.; Lundqvist, H.; Antoni, G.; Rimland, A.; Långström, B. Regional distribution of the opioid receptor agonist $\mathrm{N}$-(methyl- $\left.{ }^{11} \mathrm{C}\right)$ pethidine in the brain of the rhesus monkey studied with positron emission tomography. Pharmacol. Toxicol. 1990, 66, 37-40. [CrossRef] [PubMed]

44. Sai, K.K.; Fan, J.; Tu, Z.; Zerkel, P.; Mach, R.H.; Kharasch, E.D. Automated radiochemical synthesis and biodistribution of $\left[{ }^{11} \mathrm{C}\right] 1-\alpha$-acetylmethadol ([11 C]LAAM). Appl. Radiat. Isot. 2014, 91, 135-140. [CrossRef] 
45. Weerts, E.M.; Kim, Y.K.; Wand, G.S.; Dannals, R.F.; Lee, J.S.; Frost, J.J.; McCaul, M.E. Differences in delta- and mu-opioid receptor blockade measured by positron emission tomography in naltrexone-treated recently abstinent alcohol-dependent subjects. Neuropsychopharmacology 2008, 33, 653-665. [CrossRef]

46. Johansson, J.; Hirvonen, J.; Lovró, Z.; Ekblad, L.; Kaasinen, V.; Rajasilta, O.; Helin, S.; Tuisku, J.; Sirén, S.; Pennanen, M.; et al. Intranasal naloxone rapidly occupies brain mu-opioid receptors in human subjects. Neuropsychopharmacology 2019, 44, 1667-1673. [CrossRef]

47. Lewis, J.W. Buprenorphine. Drug Alcohol Depen. 1985, 14, 363-372. [CrossRef]

48. Lewis, J.W.; Husbands, S.M. The orvinols and related opioids-High affinity ligands with diverse efficacy profiles. Curr. Pharm. Des. 2004, 10,717-732. [CrossRef]

49. Husbands, S.M. Buprenorphine and related orvinols. In Research and Development of Opioid-Related Ligands; ACS Symposium Series; Ko, M.-C., Husbands, S.M., Eds.; American Chemical Society: Washington, DC, USA, 2013; Volume 1131, pp. 127-144.

50. Cami-Kobeci, G.; Polgar, W.E.; Khroyan, T.V.; Toll, L.; Husbands, S.M. Structural determinants of opioid and NOP receptor activity in aerivatives of buprenorphine. J. Med. Chem. 2011, 54, 6531-6537. [CrossRef]

51. Borsodi, A.; Bruchas, M.; Caló, G.; Chavkin, C.; Christie, M.J.; Civelli, O.; Connor, M.; Cox, B.M.; Devi, L.A.; Evans, C.; et al. Opioid receptors (version 2019.4) in the IUPHAR/BPS Guide to Pharmacology Database. In IUPHAR/BPS Guide to Pharmacology CITE, 2019(4); 2019. [CrossRef]

52. Stefanucci, A.; Lei, W.; Pieretti, S.; Novellino, E.; Dimmito, M.P.; Marzoli, F.; Streicher, J.M.; Mollica, A. On resin click-chemistry-mediated synthesis of novel enkephalin analogues with potent anti-nociceptive activity. Sci. Rep. 2019, 9, 5771. [CrossRef]

53. Corbett, A.D.; Paterson, S.J.; Kosterlitz, H.W. Selectivity of ligands for opioid receptors. In Handbook of Experimental Pharmacology Opioids I; Herz, A., Ed.; Springer-Verlag: New York, NY, USA, 1993; Volume 104/1, pp. 645-679.

54. Zhang, S.; Tong, Y.; Tian, M.; Dehaven, R.N.; Cortesburgos, L.; Mansson, E.; Simonin, F.; Kieffer, B.; Yu, L. Dynorphin A as a potential endogenous ligand for four members of the opioid receptor gene family. $J$. Pharmacol. Exp. Ther. 1998, 286, 136-141. [PubMed]

55. Valenzano, K.J.; Miller, W.; Chen, Z.; Shan, S.; Crumley, G.; Victory, S.F.; Davies, E.; Huang, J.-C.; Allie, N.; Nolan, S.J.; et al. DiPOA ([8-(3,3-Diphenyl-propyl)-4-oxo-1-phenyl-1,3,8-triazaspiro[4.5]dec-3-yl]-acetic acid), a novel, systemically available, and peripherally restricted mu-opioid agonist with antihyperalgesic activity: I. In vitro pharmacological characterization and pharmacokinetic properties. J. Pharmacol. Exp. Ther. 2004, 310, 783-792. [PubMed]

56. Miyazaki, T.; Choi, I.Y.; Rubas, W.; Anand, N.K.; Ali, C.; Evans, J.; Gursahani, H.; Hennessy, M.; Kim, G.; McWeeney, D.; et al. NKTR-181: A novel mu-opioid analgesic with inherently low abuse potential. J. Pharmacol. Exp. Ther. 2017, 363, 104-113. [CrossRef] [PubMed]

57. Zheng, M.Q.; Nabulsi, N.; Kim, S.J.; Tomasi, G.; Lin, S.F.; Mitch, C.; Quimby, S.; Barth, V.; Rash, K.; Masters, J.; et al. Synthesis and evaluation of ${ }^{11} \mathrm{C}$-LY2795050 as a kappa-opioid receptor antagonist radiotracer for PET imaging. J. Nucl. Med. 2013, 54, 455-463. [CrossRef]

58. Henriksen, G.; Platzer, S.; Marton, J.; Hauser, A.; Berthele, A.; Schwaiger, M.; Marinelli, L.; Lavecchia, A.; Novellino, E.; Wester, H.-J. Syntheses, biological evaluation, and molecular modeling of ${ }^{18}$ F-labeled 4-anilidopiperidines as $\mu$-opioid receptor imaging agents. J. Med. Chem. 2005, 48, 7720-7732. [CrossRef]

59. Frost, J.J.; Wagner, H.N.J.; Dannals, R.F.; Ravert, H.T.; Links, J.M.; Wilson, A.A.; Burns, H.D.; Wong, D.F.; McPherson, R.W.; Rosenbaum, A.E.; et al. Imaging opiate receptors in the human brain by positron tomography. J. Comput. Assist. Tomogr. 1985, 9, 231-236. [CrossRef]

60. Cometta-Morini, C.; Maguire, P.A.; Loew, G.H. Molecular determinants of mu receptor recognition for the fentanyl class of compounds. Mol. Pharmacol. 1992, 41, 185-196.

61. Raynor, K.; Kong, H.; Chen, Y.; Yasuda, K.; Yu, L.; Bell, G.I.; Reisine, T. Pharmacological characterization of the cloned kappa-, delta-, and mu-opioid receptors. Mol. Pharmacol. 1994, 45, 330-334.

62. Marton, J.; Schoultz, B.W.; Hjørnevik, T.; Drzezga, A.; Yousefi, B.H.; Wester, H.-J.; Willoch, F.; Henriksen, G. Synthesis and evaluation of a full-agonist orvinol for PET-Imaging of opioid receptors: $\left[{ }^{11} \mathrm{C}\right]$ PEO. J. Med. Chem. 2009, 52, 5586-5589. [CrossRef] 
63. Schoultz, B.W.; Hjørnevik, T.; Reed, B.J.; Marton, J.; Coello, C.S.; Willoch, F.; Henriksen, G. Synthesis and evaluation of three structurally related ${ }^{18} \mathrm{~F}$-labeled orvinols of different intrinsic activities: 6-O- $\left[{ }^{18} \mathrm{~F}\right]$ Fluoroethyl-diprenorphine $\left(\left[{ }^{18} \mathrm{~F}\right] \mathrm{FDPN}\right), 6-\mathrm{O}-\left[{ }^{18} \mathrm{~F}\right]$ fluoroethyl-buprenorphine $\left(\left[{ }^{18} \mathrm{~F}\right] \mathrm{FBPN}\right)$, and 6-O- $\left[{ }^{18} \mathrm{~F}\right]$ fluoroethyl-phenethyl-orvinol ([$\left.\left.{ }^{18} \mathrm{~F}\right] \mathrm{FPEO}\right)$. J. Med. Chem. 2014, 57, 5464-5469.

64. Portoghese, P.S.; Sultana, M.; Takemori, A.E. Design of peptidomimetic delta opioid receptor antagonists using the message-address concept. J. Med. Chem. 1990, 33, 1714-1720. [CrossRef] [PubMed]

65. Schoultz, B.W.; Hjornevik, T.; Willoch, F.; Marton, J.; Noda, A.; Murakami, Y.; Miyoshi, S.; Nishimura, S.; Arstad, E.; Drzezga, A.; et al. Evaluation of the kappa-opioid receptor-selective tracer $\left[{ }^{11} \mathrm{C}\right] \mathrm{GR} 103545$ in awake rhesus macaques. Eur. J. Nucl. Med. Mol. Imaging 2010, 37, 1174-1180. [CrossRef] [PubMed]

66. Zheng, M.-Q.; Kim, S.J.; Holden, D.; Lin, S.-F.; Need, A.; Rash, K.; Barth, V.; Mitch, C.; Navarro, A.; Kapinos, M.; et al. An improved antagonist radiotracer for the kappa-opioid receptor: Synthesis and characterization of ${ }^{11}$ C-LY2459989. J. Nucl. Med. 2014, 55, 1185-1191. [CrossRef] [PubMed]

67. Li, S.; Zheng, M.-Q.; Naganawa, M.; Gao, H.; Pracitto, R.; Shirali, A.; Lin, S.-F.; Teng, J.-K.; Ropchan, J.; Huang, Y. Novel kappa opioid receptor agonist as improved PET radiotracer: Development and in vivo evaluation. Mol. Pharm. 2019, 16, 1523-1531. [CrossRef] [PubMed]

68. Li, S.; Zheng, M.-Q.; Naganawa, M.; Kim, S.J.; Gao, H.; Kapinos, M.; Labaree, D.; Huang, Y. Development and in vivo evaluation of a kappa-opioid receptor agonist as a PET radiotracer with superior imaging characteristics. J. Nucl. Med. 2019, 60, 1023-1030. [CrossRef]

69. Poisnel, G.; Oueslati, F.; Dhilly, M.; Delamare, J.; Perrio, C.; Debruyne, D.; Barré, L. [ ${ }^{11}$ C]-MeJDTic: A novel radioligand for kappa-opioid receptor positron emission tomography imaging. Nucl. Med. Biol. 2008, 35, 561-569. [CrossRef]

70. Harding, W.W.; Tidgewell, K.; Byrd, N.; Cobb, H.; Dersch, C.M.; Butelman, E.R.; Rothman, R.B.; Prisinzano, T.E. Neoclerodane diterpenes as a novel scaffold for mu opioid receptor ligands. J. Med. Chem. 2005, 48, 4765-4771. [CrossRef]

71. Pike, V.W.; Rash, K.S.; Chen, Z.; Pedregal, C.; Statnick, M.A.; Kimura, Y.; Hong, J.S.; Zoghbi, S.S.; Fujita, M.; Toledo, M.A.; et al. Synthesis and evaluation of radioligands for imaging brain nociceptin/orphanin FQ peptide (NOP) receptors with positron emission tomography. J. Med. Chem. 2011, 54, 2687-2700. [CrossRef]

72. Hostetler, E.D.; Sanabria-Bohórquez, S.; Eng, W.; Joshi, A.D.; Patel, S.; Gibson, R.E.; O’Malley, S.; Krause, S.M.; Ryan, C.; Riffel, K.; et al. Evaluation of $\left[{ }^{18} \mathrm{~F}\right] \mathrm{MK}-0911$, a positron emission tomography (PET) tracer for opioid receptor-like 1 (ORL1), in rhesus monkey and human. NeuroImage 2013, 68, 1-10. [CrossRef]

73. Luthra, S.K.; Pike, V.W.; Brady, F.; Horlock, P.L.; Prenant, C.; Crouzel, C. Preparation of $\left[{ }^{11}\right.$ C]buprenorphine-A potential radioligand for the study of the opiate receptor system in vivo. Int. J. Radiat. Appl. Instrum. Part A Appl. Radiat. Isot. 1987, 38, 65-66. [CrossRef]

74. Luthra, S.K.; Pike, V.W.; Brady, F. The preparation of carbon-11 labelled diprenorphine: A new radioligand for the study of the opiate receptor system in vivo. J. Chem. Soc. Chem. Commun. 1985, 20, 1423-1425. [CrossRef]

75. Lever, J.R.; Mazza, S.M.; Dannals, R.F.; Ravert, H.T.; Wilson, A.A.; Wagner, H.N. Facile synthesis of $\left[{ }^{11} \mathrm{C}\right]$ buprenorphine for positron emission tomographic studies of opioid receptors. Int. J. Radiat. Appl. Instrum. Part A Appl. Radiat. Isot. 1990, 41, 745-752. [CrossRef]

76. Luthra, S.K.; Brady, F.; Turton, D.R.; Brown, D.J.; Dowsett, K.; Waters, S.L.; Jones, A.K.P.; Matthews, R.W.; Crowder, J.C. Automated radiosyntheses of [6-O-methyl $\left.{ }^{11} \mathrm{C}\right]$ diprenorphine and [6-O-methyl- $\left.{ }^{11} \mathrm{C}\right]$ buprenorphine from 3-O-trityl protected precursors. Appl. Radiat. Isot. 1994, 45, 857-873. [CrossRef]

77. Burns, H.D.; Lever, J.R.; Dannals, R.F.; Frost, J.J.; Wilson, A.A.; Ravert, H.T.; Subramanian, B.; Zeyman, S.E.; Langstrom, B.; Wagner, H.N., Jr. Synthesis of ligands for imaging opiate receptors by positron emission tomography: Carbon-11 labelled diprenorphine. J. Label. Compd. Radiopharm. 1984, 22, 1167-1169.

78. Lever, J.R.; Dannals, R.F.; Wilson, A.A.; Ravert, H.T.; Wagner, H.N. Synthesis of carbon-11 labeled diprenorphine: A radioligand for positron emission tomographic studies of opiate receptors. Tetrahedron Lett. 1987, 28, 4015-4018. [CrossRef]

79. Fairclough, M.; Prenant, C.; Brown, G.; McMahon, A.; Lowe, J.; Jones, A. The automated radiosynthesis and purification of the opioid receptor antagonist, $\left[6-O-\right.$ methyl $\left.-{ }^{11} \mathrm{C}\right]$ diprenorphine on the GE TRACERlab FXFE radiochemistry module. J. Label. Compd. Radiopharm. 2014, 57, 388-396. [CrossRef] 
80. Galynker, I.; Schlyer, D.J.; Dewey, S.L.; Fowler, J.S.; Logan, J.; Gatley, S.J.; MacGregor, R.R.; Ferrieri, R.A.; Holland, M.J.; Brodie, J.; et al. Opioid receptor imaging and displacement studies with [6-O-[ $\left.{ }^{11} \mathrm{C}\right]$ methyl]buprenorphine in baboon brain. Nucl. Med. Biol. 1996, 23, 325-331. [CrossRef]

81. Zubieta, J.; Greenwald, M.K.; Lombardi, U.; Woods, J.H.; Kilbourn, M.R.; Jewett, D.M.; Koeppe, R.A.; Schuster, C.R.; Johanson, C.E. Buprenorphine-induced changes in mu-opioid receptor availability in male heroin-dependent volunteers: A preliminary study. Neuropsychopharmacology 2000, 23, 326-334. [CrossRef]

82. Melichar, J.K.; Hume, S.P.; Williams, T.M.; Daglish, M.R.; Taylor, L.G.; Ahmad, R.; Malizia, A.L.; Brooks, D.J.; Myles, J.S.; Lingford-Hughes, A.; et al. Using [ $\left.{ }^{11} \mathrm{C}\right]$ diprenorphine to image opioid receptor occupancy by methadone in opioid addiction: Clinical and preclinical studies. J. Pharmacol. Exp. Ther. 2005, 312, 309-315. [CrossRef]

83. Frost, J.J.; Mayberg, H.S.; Sadzot, B.; Dannals, R.F.; Lever, J.R.; Ravert, H.T.; Wilson, A.A.; Wagner, H.N.J.; Links, J.M. Comparison of $\left[{ }^{11} \mathrm{C}\right]$ diprenorphine and $\left[{ }^{11} \mathrm{C}\right]$ carfentanil binding to opiate receptors in humans by positron emission tomography. J. Cereb. Blood Flow. Metab. 1990, 10, 484-492. [CrossRef]

84. Schadrack, J.; Willoch, F.; Platzer, S.; Bartenstein, P.; Mahal, B.; Dworzak, D.; Wester, H.J.; Zieglgänsberger, W.; Tölle, T.R. Opioid receptors in the human cerebellum: Evidence from $\left[{ }^{11} \mathrm{C}\right]$ diprenorphine PET, mRNA expression and autoradiography. Neuroreport 1999, 10, 619-624. [CrossRef] [PubMed]

85. Wester, H.-J.; Willoch, F.; Tölle, T.R.; Munz, F.; Herz, M.; Øye, I.; Schadrack, J.; Schwaiger, M.; Bartenstein, P. 6-O-(2-[ ${ }^{18}$ F]Fluoroethyl-6-O-desmethyldiprenorphine ( $\left.\left[{ }^{18} \mathrm{~F}\right] \mathrm{DPN}\right)$ : Synthesis, biologic evaluation, and comparison with $\left[{ }^{11} \mathrm{C}\right] \mathrm{DPN}$ in humans. J. Nucl. Med. 2000, 41, 1279-1286. [PubMed]

86. Schoultz, B.W.; Reed, B.J.; Marton, J.; Willoch, F.; Henriksen, G. A fully automated radiosynthesis of $\left[{ }^{18} \mathrm{~F}\right]$ fluoroethyl-diprenorphine on a single module by use of SPE cartridges for preparation of high quality 2-[18 F]fluoroethyl tosylate. Molecules 2013, 18, 7271-7278. [CrossRef] [PubMed]

87. Baumgärtner, U.; Buchholz, H.G.; Bellosevich, A.; Magerl, W.; Siessmeier, T.; Rolke, R.; Höhnemann, S.; Piel, M.; Rösch, F.; Wester, H.J.; et al. High opiate receptor binding potential in the human lateral pain system. NeuroImage 2006, 30, 692-699. [CrossRef]

88. Henriksen, G.; Spilker, M.E.; Sprenger, T.; Hauser, A.; Platzer, S.; Boecker, H.; Toelle, T.R.; Schwaiger, M.; Wester, H.J. Gender dependent rate of metabolism of the opioid receptor-PET ligand $\left[{ }^{18}\right.$ F]fluoroethyldiprenorphine. Nuklearmedizin 2006, 45, 197-200.

89. Vučković, S.; Prostran, M.; Ivanović, M.; Došen-Mićović, L.; Todorović, Z.; Nešić, Z.; Stojanović, R.; Divac, N.; Miković, Ž. Fentanyl analogs: Stuctrure-activity-relationship study. Curr. Med. Chem. 2009, 16, 2468-2474. [CrossRef]

90. Vardanyan, R.S.; Hruby, V.J. Fentanyl-related compounds and derivatives: Current status and future prospects for pharmaceutical applications. Future Med. Chem. 2014, 6, 385-412. [CrossRef]

91. Van Daele, P.G.; De Bruyn, M.F.; Boey, J.M.; Sanczuk, S.; Agten, J.T.; Janssen, P.A. Synthetic analgesics: N-(1-[2-arylethyl]-4-substituted 4-piperidinyl) N-arylalkanamides. Arzneim. Forsch. Drug Res. 1976, 26, 1521-1531.

92. Dannals, R.F.; Ravert, H.T.; Frost, J.J.; Wilson, A.A.; Burns, H.D.; Wagner, H.N.J. Radiosynthesis of an opiate receptor binding radiotracer: $\left[{ }^{11} \mathrm{C}\right]$ carfentanil. Int. J. Appl. Isot. 1985, 36, 303-306. [CrossRef]

93. Jewett, D.M.; Kilbourn, M.R. In vivo evaluation of new carfentanil-based radioligands for the mu opiate receptor. Nucl. Med. Biol. 2004, 31, 321-325. [CrossRef]

94. Shafer, S.L. Carfentanil: A weapon of mass destruction. Can. J. Anesth. 2019, 66, 351-355. [CrossRef] [PubMed]

95. Frost, J.J.; Douglass, K.H.; Mayberg, H.S.; Dannals, R.F.; Links, J.M.; Wilson, A.A.; Ravert, H.T.; Crozier, W.C.; Wagner, H.N.J. Multicompartmental analysis of $\left[{ }^{11} \mathrm{C}\right]$-carfentanil binding to opiate receptors in humans measured by positron emission tomography. J. Cereb. Blood Flow. Metab. 1989, 9, 398-409. [CrossRef] [PubMed]

96. Hirvonen, J.; Aalto, S.; Hagelberg, N.; Maksimow, A.; Ingman, K.; Oikonen, V.; Virkkala, J.; Någren, K.; Scheinin, H. Measurement of central mu-opioid receptor binding in vivo with PET and $\left[{ }^{11} \mathrm{C}\right]$ carfentanil: A test-retest study in healthy subjects. Eur. J. Nucl. Med. Mol. Imaging 2009, 36, 275-286. [CrossRef] [PubMed]

97. Bentley, K.W.; Hardy, D.G. Novel analgesics and molecular rearrangements in the morphine-thebaine group. III. Alcohols of the 6,14-endo-ethenotetrahydrooripavine series and derived analogs of $N$-allylnormorphine and -norcodeine. J. Am. Chem. Soc. 1967, 89, 3281-3292. [CrossRef] 
98. Marton, J.; Henriksen, G. Design and synthesis of an ${ }^{18} \mathrm{~F}$-labeled version of phenylethyl orvinol ([$\left.\left.{ }^{18} \mathrm{~F}\right] \mathrm{FE}-\mathrm{PEO}\right)$ for PET-imaging of opioid receptors. Molecules 2012, 17, 11554-11569. [CrossRef]

99. Riss, P.J.; Hong, Y.T.; Marton, J.; Caprioli, D.; Williamson, D.J.; Ferrari, V.; Saigal, N.; Roth, B.L.; Henriksen, G.; Fryer, T.D.; et al. Synthesis and evaluation of ${ }^{18}$ F-FE-PEO in rodents: An ${ }^{18}$ F-labeled full agonist for opioid receptor imaging. J. Nucl. Med. 2013, 54, 299-305. [CrossRef]

100. Lever, J.R.; Kinter, C.M.; Ravert, H.T.; Musachio, J.L.; Mathews, W.B.; Dannals, R.F. Synthesis of $N 1^{\prime}-\left(\left[{ }^{11} \mathrm{C}\right]\right.$ methyl)naltrindole $\left(\left[{ }^{11} \mathrm{C}\right] \mathrm{MeNTI}\right)$ : A radioligand for positron emission tomographic studies of delta opioid receptors. J. Label. Compd. Radiopharm. 1995, 36, 137-145. [CrossRef]

101. Madar, I.; Lever, J.R.; Kinter, C.M.; Scheffel, U.; Ravert, H.T.; Musachio, J.L.; Mathews, W.B.; Dannals, R.F.; Frost, J.J. Imaging of delta opioid receptors in human brain by $N 1^{\prime}-\left(\left[{ }^{11} \mathrm{C}\right]\right.$ methyl)naltrindole and PET. Synapse 1996, 24, 19-28. [CrossRef]

102. Smith, J.S.; Zubieta, J.K.; Price, J.C.; Flesher, J.E.; Madar, I.; Lever, J.R.; Kinter, C.M.; Dannals, R.F.; Frost, J.J. Quantification of delta-opioid receptors in human brain with $N 1^{\prime}-\left(\left[{ }^{11} \mathrm{C}\right]\right.$ methyl) naltrindole and positron emission tomography. J. Cereb. Blood Flow. Metab. 1999, 19, 956-966. [CrossRef]

103. Mathews, W.B.; Kinter, C.M.; Palma, J.; Daniels, R.V.; Ravert, H.T.; Dannals, R.F.; Lever, J.R. Synthesis of $N 1^{\prime}-\left(\left[{ }^{18} \mathrm{~F}\right]\right.$ fluoroethyl)naltrindole $\left(\left[{ }^{18} \mathrm{~F}\right] \mathrm{FEtNTI}\right)$ : A radioligand for positron emission tomographic studies of delta opioid receptors. J. Label. Compd. Radiopharm. 1999, 42, 43-54. [CrossRef]

104. Tyacke, R.J.; Robinson, E.S.; Schnabel, R.; Lewis, J.W.; Husbands, S.M.; Nutt, D.J.; Hudson, A.L. $N 1$ '-fluoroethyl-naltrindole (BU97001) and N1'-fluoroethyl-(14-formylamino)-naltrindole (BU97018) potential delta-opioid receptor PET ligands. Nucl. Med. Biol. 2002, 29, 455-462. [CrossRef]

105. Bourdier, T.; Poisnel, G.; Dhilly, M.; Delamare, J.; Henry, J.; Debruyne, D.; Barré, L. Synthesis and biological evaluation of $\mathrm{N}$-substituted quinolinimides, as potential ligands for in vivo imaging studies of delta-opioid receptors. Bioconj. Chem. 2007, 18, 538-548. [CrossRef] [PubMed]

106. Hayes, A.G.; Birch, P.J.; Hayward, N.J.; Sheehan, M.J.; Rogers, H.; Tyers, M.B.; Judd, D.B.; Scopes, D.I.C.; Naylor, A. A series of novel, highly potent and selective agonists for the kappa-opioid receptor. Br. J. Pharmacol. 1990, 101, 944-948. [CrossRef]

107. Birch, P.J.; Rogers, H.; Hayes, A.G.; Hayward, N.J.; Tyers, M.B.; Scopes, D.I.C.; Naylor, A.; Judd, D.B. Neuroprotective actions of GR89696, a highly potent and selective K-opioid receptor agonist. Br. J. Pharmacol. 1991, 103, 1819-1823. [CrossRef] [PubMed]

108. Naylor, A.; Judd, D.B.; Lloyd, J.E.; Scopes, D.I.C.; Hayes, A.G.; Birch, P.J. A potent new class of kappa-receptor agonist: 4-substituted 1-(arylacetyl)-2-[(dialkylamino)methyl]piperazines. J. Med. Chem. 1993, 36, 2075-2083. [CrossRef] [PubMed]

109. Ravert, H.T.; Mathews, W.B.; Musachio, J.L.; Scheffel, U.; Finley, P.; Dannals, R.F. [ ${ }^{11}$ C]-methyl 4-[(3,4-dichlorophenyl)acetyl]-3-[(1-pyrrolidinyl)methyl]-1-piperazinecarboxylate ([$\left.\left.{ }^{11} \mathrm{C}\right] \mathrm{GR} 89696\right)$ : Synthesis and in vivo binding to kappa opiate receptors. Nucl. Med. Biol. 1999, 26, 737-741. [CrossRef]

110. Ravert, H.T.; Scheffel, U.; Mathews, W.B.; Musachio, J.L.; Dannals, R.F. [ ${ }^{11}$ C]-GR89696, a potent kappa opiate receptor radioligand; in vivo binding of the $R$ and $S$ enantiomers. Nucl. Med. Biol. 2002, 29, 47-53. [CrossRef]

111. Talbot, P.S.; Narendran, R.; Butelman, E.R.; Huang, Y.; Ngo, K.; Slifstein, M.; Martinez, D.; Laruelle, M.; Hwang, D.R. ${ }^{11}$ C-GR103545, a radiotracer for imaging kappa-opioid receptors in vivo with PET: Synthesis and evaluation in baboons. J. Nucl. Med. 2005, 46, 484-494.

112. Schoultz, B.W.; Arstad, E.; Marton, J.; Willoch, F.; Drzezga, A.; Wester, H.J.; Henriksen, G. A new method for radiosynthesis of ${ }^{11} \mathrm{C}$-labeled carbamate groups and its application for a highly efficient synthesis of the kappa-opioid receptor tracer $\left[{ }^{11} \mathrm{C}\right] \mathrm{GR} 103545$. Open Med. Chem. J. 2008, 2, 72-74. [CrossRef]

113. Wilson, A.A.; Gracia, A.; Houle, S.; Vasdev, N. Direct fixation of $\left[{ }^{11} \mathrm{C}\right]-\mathrm{CO}_{2}$ by amines: Formation of [11C-carbonyl]-methylcarbamates. Org. Biomol. Chem. 2010, 8, 428-432. [CrossRef]

114. Nabulsi, N.B.; Zheng, M.-Q.; Ropchan, J.; Labaree, D.; Ding, Y.-S.; Blumberg, L.; Huang, Y. [ ${ }^{11}$ C]GR103545: Novel one-pot radiosynthesis with high specific activity. Nucl. Med. Biol. 2011, 38, 215-221. [CrossRef] [PubMed]

115. Tomasi, G.; Nabulsi, N.; Zheng, M.Q.; Weinzimmer, D.; Ropchan, J.; Blumberg, L.; Brown-Proctor, C.; Ding, Y.S.; Carson, R.E.; Huang, Y. Determination of in vivo Bmax and Kd for ${ }^{11}$ C-GR103545, an agonist PET tracer for kappa-opioid receptors: A study in nonhuman primates. J. Nucl. Med. 2013, 54, 600-608. [CrossRef] [PubMed] 
116. Naganawa, M.; Jacobsen, L.K.; Zheng, M.-Q.; Lin, S.-F.; Banerjee, A.; Byon, W.; Weinzimmer, D.; Tomasi, G.; Nabulsi, N.; Grimwood, S.; et al. Evaluation of the agonist PET radioligand $\left[{ }^{11} \mathrm{C}\right] \mathrm{GR} 103545$ to image kappa opioid receptor in humans: Kinetic model selection, test-retest reproducibility and receptor occupancy by the antagonist PF-04455242. NeuroImage 2014, 99, 69-79. [CrossRef] [PubMed]

117. Li, S.; Cai, Z.; Zheng, M.-Q.; Holden, D.; Naganawa, M.; Lin, S.-F.; Ropchan, J.; Labaree, D.; Kapinos, M.; Lara-Jaime, T.; et al. Novel ${ }^{18} \mathrm{~F}$-labeled kappa-opioid receptor antagonist as PET radiotracer: Synthesis and in vivo evaluation of ${ }^{18}$ F-LY2459989 in nonhuman primates. J. Nucl. Med. 2018, 59, 140-146. [CrossRef]

118. Fichna, J.; Schicho, R.; Janecka, A.; Zjawiony, J.K.; Storr, M. Selective natural kappa opioid and cannabinoid receptor agonists with a potential role in the treatment of gastrointestinal dysfunction. Drug News Perspect. 2009, 22, 383-392. [CrossRef]

119. Butelman, E.R.; Kreek, M.J. Salvinorin A, a kappa-opioid receptor agonist hallucinogen: Pharmacology and potential template for novel pharmacotherapeutic agents in neuropsychiatric disorders. Front. Pharmacol. 2015, 6, 190.

120. Zjawiony, J.K.; Machado, A.S.; Menegatti, R.; Ghedini, P.C.; Costa, E.A.; Pedrino, G.R.; Lukas, S.E.; Franco, O.L.; Silva, O.N.; Fajemiroye, J.O. Cutting-edge search for safer opioid pain relief: Retrospective review of Salvinorin A and its analogs. Front. Psychiatry 2019, 10(157), 1-11. [CrossRef]

121. Hooker, J.M.; Xu, Y.; Schiffer, W.; Shea, C.; Carter, P.; Fowler, J.S. Pharmacokinetics of the potent hallucinogen, salvinorin A in primates parallels the rapid onset and short duration of effects in humans. NeuroImage 2008, 41, 1044-1050. [CrossRef]

122. Placzek, M.S.; Van de Bittner, G.C.; Wey, H.Y.; Lukas, S.E.; Hooker, J.M. Immediate and persistent effects of Salvinorin A on the kappa opioid receptor in rodents, monitored in vivo with PET. Neuropsychopharmacology 2015, 40, 2865-2872. [CrossRef]

123. Thomas, J.B.; Atkinson, R.N.; Rothman, R.B.; Fix, S.E.; Mascarella, S.W.; Vinson, N.A.; Xu, H.; Dersch, C.M.; $\mathrm{Lu}$, Y.F.; Cantrell, B.E.; et al. Identification of the first trans-(3R,4R)-dimethyl-4-(3-hydroxyphenyl)piperidine derivative to possess highly potent and selective opioid kappa receptor antagonist activity. J. Med. Chem. 2001, 44, 2687-2690. [CrossRef]

124. Schmitt, S.; Delamare, J.; Tirel, O.; Fillesoye, F.; Dhilly, M.; Perrio, C. N-[ ${ }^{18}$ F]-FluoropropylJDTic for kappa-opioid receptor PET imaging: Radiosynthesis, pre-clinical evaluation, and metabolic investigation in comparison with parent JDTic. Nucl. Med. Biol. 2017, 44, 50-61. [CrossRef] [PubMed]

125. Kim, S.J.; Zheng, M.Q.; Nabulsi, N.; Labaree, D.; Ropchan, J.; Najafzadeh, S.; Carson, R.E.; Huang, Y.; Morris, E.D. Determination of the in vivo selectivity of a new kappa-opioid receptor antagonist PET tracer ${ }^{11}$ C-LY2795050 in the rhesus monkey. J. Nucl. Med. 2013, 54, 1668-1674. [CrossRef] [PubMed]

126. Naganawa, M.; Zheng, M.Q.; Nabulsi, N.; Tomasi, G.; Henry, S.; Lin, S.F.; Ropchan, J.; Labaree, D.; Tauscher, J.; Neumeister, A.; et al. Kinetic modeling of ${ }^{11}$ C-LY2795050, a novel antagonist radiotracer for PET imaging of the kappa opioid receptor in humans. J. Cereb. Blood Flow. Metab. 2014, 34, 1818-1825. [CrossRef]

127. Naganawa, M.; Zheng, M.-Q.; Henry, S.; Nabulsi, N.; Lin, S.-F.; Ropchan, J.; Labaree, D.; Najafzadeh, S.; Kapinos, M.; Tauscher, J.; et al. Test-Retest Reproducibility of Binding Parameters in Humans with ${ }^{11}$ C-LY2795050, an Antagonist PET Radiotracer for the kappa Opioid Receptor. J. Nucl. Med. 2015, 56, 243-248. [CrossRef] [PubMed]

128. Naganawa, M.; Dickinson, G.L.; Zheng, M.-Q.; Henry, S.; Vandenhende, F.; Witcher, J.; Bell, R.; Nabulsi, N.; Lin, S.-F.; Ropchan, J.; et al. Receptor occupancy of the kappa-opioid antagonist LY2456302 measured with positron emission tomography and the novel radiotracer ${ }^{11}$ C-LY2795050. J. Pharmacol. Exp. Ther. 2016, 356, 260-266. [CrossRef]

129. Placzek, M.S.; Schroeder, F.A.; Che, T.; Wey, H.-Y.; Neelamegam, R.; Wang, C.; Roth, B.L.; Hooker, J.M. Discrepancies in kappa opioid agonist binding revealed through PET Imaging. ACS Chem. Neurosci. 2019, 10, 384-395. [CrossRef]

130. Chesis, P.L.; Welch, M.J. Synthesis and in vitro characterization of fluorinated U-50488 analogs for PET studies of kappa opioid receptors. Int. J. Radiat. Applicat. Instrum. Part A Appl. Radiat. Isot. 1990, 41, 267-273. [CrossRef]

131. Zaveri, N.T. Nociceptin opioid receptor (NOP) as a therapeutic target: Progress in translation from preclinical research to clinical utility. J. Med. Chem. 2016, 59, 7011-7028. [CrossRef] 
132. Kimura, Y.; Fujita, M.; Hong, J.S.; Lohith, T.G.; Gladding, R.L.; Zoghbi, S.S.; Tauscher, J.A.; Goebl, N.; Rash, K.S.; Chen, Z.; et al. Brain and whole-body imaging in rhesus monkeys of ${ }^{11} \mathrm{C}-\mathrm{NOP}-1 \mathrm{~A}$, a promising PET radioligand for nociceptin/orphanin FQ peptide receptors. J. Nucl. Med. 2011, 52, 1638-1645. [CrossRef]

133. Lohith, T.G.; Zoghbi, S.S.; Morse, C.L.; Araneta, M.F.; Barth, V.N.; Goebl, N.A.; Tauscher, J.T.; Pike, V.W.; Innis, R.B.; Fujita, M. Brain and whole-body imaging of nociceptin/orphanin FQ peptide receptor in humans using the PET Ligand ${ }^{11} \mathrm{C}-\mathrm{NOP}-1 \mathrm{~A}$. . . Nucl. Med. 2012, 53, 385-392. [CrossRef]

134. Lohith, T.G.; Zoghbi, S.S.; Morse, C.L.; Araneta, M.D.F.; Barth, V.N.; Goebl, N.A.; Tauscher, J.T.; Pike, V.W.; Innis, R.B.; Fujita, M. Retest imaging of $\left[{ }^{11} \mathrm{C}\right] \mathrm{NOP}-1 \mathrm{~A}$ binding to nociceptin/orphanin FQ peptide (NOP) receptors in the brain of healthy humans. NeuroImage 2014, 87, 89-95. [CrossRef] [PubMed]

135. Raddad, E.; Chappell, A.; Meyer, J.; Wilson, A.A.; Ruegg, C.E.; Tauscher, J.; Statnick, M.A.; Barth, V.; Zhang, X.; Verfaille, S.J. Occupancy of nociceptin/orphanin FQ peptide receptors by the antagonist LY2940094 in rats and healthy human subjects. Drug Metab. Dispos. 2016, 44, 1536-1542. [CrossRef] [PubMed]

136. Zhang, L.; Drummond, E.; Brodney, M.A.; Cianfrogna, J.; Drozda, S.E.; Grimwood, S.; Vanase-Frawley, M.A.; Villalobos, A. Design, synthesis and evaluation of $\left[{ }^{3} \mathrm{H}\right] \mathrm{PF}-7191$, a highly specific nociceptin opioid peptide (NOP) receptor radiotracer for in vivo receptor occupancy (RO) studies. Bioorg. Med. Chem. Lett. 2014, 24, 5219-5223. [CrossRef] [PubMed]

137. Zubieta, J.K.; Dannals, R.F.; Frost, J.J. Gender and age influences on human brain mu-opioid receptor binding measured by PET. Am. J. Psychiarty 1999, 156, 842-848. [CrossRef] [PubMed]

138. Vijay, A.; Cavallo, D.; Goldberg, A.; de Laat, B.; Nabulsi, N.; Huang, Y.; Krishnan-Sarin, S.; Morris, E.D. PET imaging reveals lower kappa opioid receptor availability in alcoholics but no effect of age. Neuropsychopharmacology 2018, 43, 2539-2547. [CrossRef]

139. Vijay, A.; Wang, S.; Worhunsky, P.; Zheng, M.-Q.; Nabulsi, N.; Ropchan, J.; Krishnan-Sarin, S.; Huang, Y.; Morris, E.D. PET imaging reveals sex differences in kappa opioid receptor availability in humans, in vivo. Am. J. Nucl. Med. Mol. Imaging 2016, 6, 205-214. [PubMed]

140. Mayberg, H.S.; Sadzot, B.; Meltzer, C.C.; Fisher, R.S.; Lesser, R.P.; Dannals, R.F.; Lever, J.R.; Wilson, A.A.; Ravert, H.T.; Wagner, H.N.J.; et al. Quantification of mu and non-mu opiate receptors in temporal lobe epilepsy using positron emission tomography. Ann. Neurol. 1991, 30, 3-11. [CrossRef]

141. Madar, I.; Lesser, R.P.; Krauss, G.; Zubieta, J.K.; Lever, J.R.; Kinter, C.M.; Ravert, H.T.; Musachio, J.L.; Mathews, W.B.; Dannals, R.F.; et al. Imaging of $\delta$ - and $\mu$-opioid receptors in temporal lobe epilepsy by positron emission tomography. Ann. Neurol. 1997, 41, 358-367. [CrossRef]

142. Hammers, A.; Asselin, M.-C.; Hinz, R.; Kitchen, I.; Brooks, D.J.; Duncan, J.S.; Koepp, M.J. Upregulation of opioid receptor binding following spontaneous epileptic seizures. Brain 2007, 130, 1009-1016. [CrossRef]

143. McGinnity, C.J.; Shidahara, M.; Feldmann, M.; Keihaninejad, S.; Riaño Barros, D.A.; Gousias, I.S.; Duncan, J.S.; Brooks, D.J.; Heckemann, R.A.; Turkheimer, F.E.; et al. Quantification of opioid receptor availability following spontaneous epileptic seizures: Correction of $\left[{ }^{11} \mathrm{C}\right]$ diprenorphine PET data for the partial-volume effect. NeuroImage 2013, 79, 72-80. [CrossRef]

144. Koepp, M.J.; Richardson, M.P.; Brooks, D.J.; Duncan, J.S. Focal cortical release of endogenous opioids during reading induced seizures. Lancet 1998, 352, 952-955. [CrossRef]

145. Cohen, R.M.; Carson, R.E.; Aigner, T.G.; Doudet, D.J. Opiate receptor avidity is reduced in non-motor impaired MPTP-lesioned rhesus monkeys. Brain Res. 1998, 806, 292-296. [CrossRef]

146. Cohen, R.M.; Carson, R.E.; Wyatt, R.J.; Doudet, D.J. Opiate receptor avidity is reduced bilaterally in rhesus monkeys unilaterally lesioned with MPTP. Synapse 1999, 33, 282-288. [CrossRef]

147. Piccini, P.; Weeks, R.A.; Brooks, D.J. Alterations in opioid receptor binding in Parkinson's disease patients with levodopa-induced dyskinesias. Ann. Neurol. 1997, 42, 720-726. [CrossRef] [PubMed]

148. Whone, A.L.; Von Spiczak, S.; Edwards, M.; Valente, E.-M.; Hammers, A.; Bhatia, K.P.; Brooks, D.J. Opioid binding in DYT1 primary torsion dystonia: An ${ }^{11}$ C-diprenorphine PET study. Mov. Dis. 2004, 19, 1498-1503. [CrossRef] [PubMed]

149. Von Spiczak, S.; Whone, A.L.; Hammers, A.; Asselin, M.-C.; Turkheimer, F.; Tings, T.; Happe, S.; Paulus, W.; Trenkwalder, C.; Brooks, D.J. The role of opioids in restless legs syndrome: An $\left[{ }^{11} \mathrm{C}\right]$ diprenorphine PET study. Brain 2005, 128, 906-917. [CrossRef] [PubMed]

150. Weeks, R.A.; Cunningham, V.J.; Piccini, P.; Waters, S.; Harding, A.E.; Brooks, D.J. ${ }^{11}$ C-Diprenorphine binding in Huntington's disease: A comparison of region of interest analysis with statistical parametric mapping. J. Cereb. Blood Flow. Metab. 1997, 17, 943-949. [CrossRef] 
151. Willoch, F.; Tölle, T.R.; Wester, H.-J.; Munz, F.; Petzold, A.; Schwaiger, M.; Conrad, B.; Bartenstein, P. Central pain after pontine infarction is associated with changes in opioid receptor binding: A PET study with ${ }^{11}$ C-Diprenorphine. AJNR Am. J. Neuroradiol. 1999, 20, 686-690.

152. Willoch, F.; Schindler, F.; Wester, H.-J.; Empl, M.; Straube, A.; Schwaiger, M.; Conrad, B.; Tölle, T.R. Central poststroke pain and reduced opioid receptor binding within pain processing circuitries: $\mathrm{A}\left[{ }^{11} \mathrm{C}\right]$ diprenorphine PET study. Pain 2004, 108, 213-220. [CrossRef]

153. Maarrawi, J.; Peyron, R.; Mertens, P.; Costes, N.; Magnin, M.; Sindou, M.; Laurent, B.; Garcia-Larrea, L. Differential brain opioid receptor availability in central and peripheral neuropathic pain. Pain 2007, 127, 183-194. [CrossRef]

154. Campbell, C.M.; Bounds, S.C.; Kuwabara, H.; Edwards, R.R.; Campbell, J.N.; Haythornthwaite, J.A.; Smith, M.T. Individual variation in sleep quality and duration is related to cerebral mu opioid receptor binding potential during tonic laboratory pain in healthy subjects. Pain Med. 2013, 14, 1882-1892. [CrossRef] [PubMed]

155. Bencherif, B.; Fuchs, P.N.; Sheth, R.; Dannals, R.F.; Campbell, J.N.; Frost, J.J. Pain activation of human supraspinal opioid pathways as demonstrated by $\left[{ }^{11} \mathrm{C}\right]$-carfentanil and positron emission tomography (PET). Pain 2002, 99, 589-598. [CrossRef]

156. Sprenger, T.; Valet, M.; Boecker, H.; Henriksen, G.; Spilker, M.E.; Willoch, F.; Wagner, K.J.; Wester, H.J.; Tölle, T.R. Opioidergic activation in the medial pain system after heat pain. Pain 2006, 122, 63-67. [CrossRef] [PubMed]

157. Zubieta, J.K.; Smith, Y.R.; Bueller, J.A.; Xu, Y.; Kilbourn, M.R.; Jewett, D.M.; Meyer, C.R.; Koeppe, R.A.; Stohler, C.S. Regional mu opioid receptor regulation of sensory and affective dimensions of pain. Science 2001, 293, 311-315. [CrossRef] [PubMed]

158. Zubieta, J.K.; Smith, Y.R.; Bueller, J.A.; Xu, Y.; Kilbourn, M.R.; Jewett, D.M.; Meyer, C.R.; Koeppe, R.A.; Stohler, C.S. Mu-opioid receptor-mediated antinociceptive responses differ in men and women. J. Neurosci. 2002, 22, 5100-5107. [CrossRef] [PubMed]

159. DosSantos, M.F.; Martikainen, I.K.; Nascimento, T.D.; Love, T.M.; Deboer, M.D.; Maslowski, E.C.; Monteiro, A.A.; Vincent, M.B.; Zubieta, J.K.; DaSilva, A.F. Reduced basal ganglia mu-opioid receptor availability in trigeminal neuropathic pain: A pilot study. Mol. Pain 2012, 8, 74. [CrossRef]

160. Scott, D.J.; Stohler, C.S.; Koeppe, R.A.; Zubieta, J.K. Time-course of change in $\left.{ }^{11} \mathrm{C}\right]$ carfentanil and $\left[{ }^{11} \mathrm{C}\right]$ raclopride binding potential after a nonpharmacological challenge. Synapse 2007, 61,707-714. [CrossRef]

161. Hjornevik, T.; Schoultz, B.W.; Marton, J.; Gjerstad, J.; Drzezga, A.; Henriksen, G.; Willoch, F. Spinal long-term potentiation is associated with reduced opioid neurotransmission in the rat brain. Clin. Physiol. Funct. Imaging 2010, 30, 285-293. [CrossRef]

162. Boecker, H.; Sprenger, T.; Spilker, M.E.; Henriksen, G.; Koppenhoefer, M.; Wagner, K.J.; Valet, M.; Berthele, A.; Tolle, T.R. The runner's high: Opioidergic mechanisms in the human brain. Cereb. Cortex 2008, 18, 2523-2531. [CrossRef]

163. Saanijoki, T.; Tuominen, L.; Tuulari, J.J.; Nummenmaa, L.; Arponen, E.; Kalliokoski, K.; Hirvonen, J. Opioid release after high-intensity interval training in healthy human subjects. Neuropsychopharmacol 2018, 43, 246-254. [CrossRef]

164. Maarrawi, J.; Peyron, R.; Mertens, P.; Costes, N.; Magnin, M.; Sindou, M.; Laurent, B.; Garcia-Larrea, L. Motor cortex stimulation for pain control induces changes in the endogenous opioid system. Neurology 2007, 69, 827-834. [CrossRef] [PubMed]

165. DosSantos, M.F.; Love, T.M.; Martikainen, I.K.; Nascimento, T.D.; Fregni, F.; Cummiford, C.; Deboer, M.D.; Zubieta, J.K.; DaSilva, A.F. Immediate Effects of tDCS on the mu-opioid system of a chronic pain patient. Front. Psychiatry 2012, 3, 93. [PubMed]

166. Maarrawi, J.; Peyron, R.; Mertens, P.; Costes, N.; Magnin, M.; Sindou, M.; Laurent, B.; Garcia-Larrea, L. Brain opioid receptor density predicts motor cortex stimulation efficacy for chronic pain. Pain 2013, 154, 2563-2568. [CrossRef] [PubMed]

167. Sims-Williams, H.; Matthews, J.C.; Talbot, P.S.; Love-Jones, S.; Brooks, J.C.; Patel, N.K.; Pickering, A.E. Deep brain stimulation of the periaqueductal gray releases endogenous opioids in humans. NeuroImage 2017, 146, 833-842. [CrossRef] 
168. Ly, H.G.; Dupont, P.; Geeraerts, B.; Bormans, G.; Van Laere, K.; Tack, J.; Van Oudenhove, L. Lack of endogenous opioid release during sustained visceral pain: A $\left[{ }^{11} \mathrm{C}\right]$ carfentanil PET study. Pain 2013, 154, 2072-2077. [CrossRef]

169. Baier, B.; Bense, S.; Birklein, F.; Buchholz, H.-G.; Mischke, A.; Schreckenberger, M.; Dieterich, M. Evidence for modulation of opioidergic activity in central vestibular processing: A [ $\left.{ }^{18} \mathrm{~F}\right]$ diprenorphine PET study. Hum. Brain Mapp. 2010, 31, 550-555. [CrossRef]

170. Wager, T.D.; Scott, D.J.; Zubieta, J.K. Placebo effects on human mu-opioid activity during pain. Proc. Natl. Acad. Sci. USA 2007, 104, 11056-11061. [CrossRef]

171. DosSantos, M.F.; Martikainen, I.K.; Nascimento, T.D.; Love, T.M.; DeBoer, M.D.; Schambra, H.M.; Bikson, M.; Zubieta, J.K.; DaSilva, A.F. Building up analgesia in humans via the endogenous mu-opioid system by combining placebo and active tDCS: A preliminary report. PLoS ONE 2014, 9, e102350. [CrossRef]

172. Dougherty, D.D.; Kong, J.; Webb, M.; Bonab, A.A.; Fischman, A.J.; Gollub, R.L. A combined $\left[{ }^{11}\right.$ C]diprenorphine PET study and fMRI study of acupuncture analgesia. Behav. Brain Res. 2008, 193, 63-68. [CrossRef]

173. Harris, R.E.; Zubieta, J.K.; Scott, D.J.; Napadow, V.; Gracely, R.H.; Clauw, D.J. Traditional Chinese acupuncture and placebo (sham) acupuncture are differentiated by their effects on mu-opioid receptors (MORs). NeuroImage 2009, 47, 1077-1085. [CrossRef]

174. Xiang, X.-H.; Chen, Y.-M.; Zhang, J.-M.; Tian, J.-H.; Han, J.-S.; Cui, C.-L. Low- and high-frequency transcutaneous electrical acupoint stimulation induces different effects on cerebral mu-opioid receptor availability in rhesus monkeys. J. Neurosci. Res. 2014, 92, 555-563. [CrossRef] [PubMed]

175. Mueller, C.; Klega, A.; Buchholz, H.-G.; Rolke, R.; Magerl, W.; Schirrmacher, R.; Schirrmacher, E.; Birklein, F.; Treede, R.-D.; Schreckenberger, M. Basal opioid receptor binding is associated with differences in sensory perception in healthy human subjects: A $\left[{ }^{18}\right.$ F]diprenorphine PET study. NeuroImage 2010, 49, 731-737. [CrossRef] [PubMed]

176. Hagelberg, N.; Aalto, S.; Tuominen, L.; Pesonen, U.; Någren, K.; Hietala, J.; Scheinin, H.; Pertovaara, A.; Martikainen, I.K. Striatal mu-opioid receptor availability predicts cold pressor pain threshold in healthy human subjects. Neurosci. Lett. 2012, 521, 11-14. [CrossRef] [PubMed]

177. Thompson, S.J.; Pitcher, M.H.; Stone, L.S.; Tarum, F.; Niu, G.; Chen, X.; Kiesewetter, D.O.; Schweinhardt, P.; Bushnell, M.C. Chronic neuropathic pain reduces opioid receptor availability with associated anhedonia in rat. Pain 2018, 159, 1856-1866. [CrossRef] [PubMed]

178. Sprenger, T.; Willoch, F.; Miederer, M.; Schindler, F.; Valet, M.; Berthele, A.; Spilker, M.E.; Förderreuther, S.; Straube, A.; Stangier, I.; et al. Opioidergic changes in the pineal gland and hypothalamus in cluster headache: A ligand PET study. Neurology 2006, 66, 1108-1110. [CrossRef]

179. DaSilva, A.F.; Nascimento, T.D.; DosSantos, M.F.; Lucas, S.; van Holsbeeck, H.; DeBoer, M.; Maslowski, E.; Love, T.; Martikainen, I.K.; Koeppe, R.A.; et al. Mu-Opioid activation in the prefrontal cortex in migraine attacks-Brief report I. Ann. Clin. Transl. Neurol. 2014, 1, 439-444. [CrossRef]

180. Linnman, C.; Catana, C.; Petkov, M.P.; Chonde, D.B.; Becerra, L.; Hooker, J.; Borsook, D. Molecular and functional PET-fMRI measures of placebo analgesia in episodic migraine: Preliminary findings. NeuroImage Clin. 2018, 17, 680-690. [CrossRef]

181. Schreckenberger, M.; Klega, A.; Gründer, G.; Buchholz,H.-G.; Scheurich, A.; Schirrmacher, R.; Schirrmacher, E.; Müller, C.; Henriksen, G.; Bartenstein, P. Opioid receptor PET reveals the psychobiologic correlates of reward processing. J. Nucl. Med. 2008, 49, 1257-1261. [CrossRef]

182. Tuominen, L.; Salo, J.; Hirvonen, J.; Någren, K.; Laine, P.; Melartin, T.; Isometsä, E.; Viikari, J.; Raitakari, O.; Keltikangas-Järvinen, L.; et al. Temperament trait harm avoidance associates with mu-opioid receptor availability in frontal cortex: A PET study using $\left[{ }^{11} \mathrm{C}\right]$ carfentanil. NeuroImage 2012, 61, 670-676. [CrossRef]

183. Karjalainen, T.; Tuominen, L.; Manninen, S.; Kalliokoski, K.K.; Nuutila, P.; Jääskeläinen, I.P.; Hari, R.; Sams, M.; Nummenmaa, L. Behavioural activation system sensitivity is associated with cerebral mu-opioid receptor availability. Soc. Cogn. Affect. Neurosci. 2016, 11, 1310-1316. [CrossRef]

184. Nummenmaa, L.; Manninen, S.; Tuominen, L.; Hirvonen, J.; Kalliokoski, K.K.; Nuutila, P.; Jääskeläinen, I.P.; Hari, R.; Dunbar, R.I.; Sams, M. Adult attachment style is associated with cerebral mu-opioid receptor availability in humans. Hum. Brain Mapp. 2015, 36, 3621-3628. [CrossRef]

185. Karjalainen, T.; Seppälä, K.; Glerean, E.; Karlsson, H.K.; Lahnakoski, J.M.; Nuutila, P.; Jääskeläinen, I.P.; Hari, R.; Sams, M.; Nummenmaa, L. Opioidergic Regulation of Emotional Arousal: A Combined PET-fMRI Study. Cereb. Cortex 2018, 29, 4006-4016. [CrossRef] 
186. Nummenmaa, L.; Tuominen, L.; Dunbar, R.; Hirvonen, J.; Manninen, S.; Arponen, E.; Machin, A.; Hari, R.; Jääskeläinen, I.P.; Sams, M. Social touch modulates endogenous mu-opioid system activity in humans. NeuroImage 2016, 138, 242-247. [CrossRef]

187. Manninen, S.; Tuominen, L.; Dunbar, R.I.; Karjalainen, T.; Hirvonen, J.; Arponen, E.; Hari, R.; Jääskeläinen, I.P.; Sams, M.; Nummenmaa, L. Social laughter triggers endogenous opioid release in humans. J. Neurosci. 2017, 37, 6125-6131. [CrossRef]

188. Prossin, A.R.; Koch, A.E.; Campbell, P.L.; Barichello, T.; Zalcman, S.S.; Zubieta, J.-K. Acute experimental changes in mood state regulate immune function in relation to central opioid neurotransmission: A model of human CNS-peripheral inflammatory interaction. Mol. Psychiatry 2016, 21, 243-251. [CrossRef]

189. Kennedy, S.E.; Koeppe, R.A.; Young, E.A.; Zubieta, J.K. Dysregulation of Endogenous Opioid Emotion Regulation Circuitry in Major Depression in Women. Arch. Gen. Psychiatry. 2006, 63, 1199-1208. [CrossRef]

190. Miller, J.M.; Zanderigo, F.; Purushothaman, P.D.; DeLorenzo, C.; Rubin-Falcone, H.; Ogden, R.T.; Keilp, J.; Oquendo, M.A.; Nabulsi, N.; Huang, Y.H.; et al. Kappa opioid receptor binding in major depression: A pilot study. Synapse 2018, 72, e22042. [CrossRef]

191. Matuskey, D.; Dias, M.; Naganawa, M.; Pittman, B.; Henry, S.; Li, S.; Gao, H.; Ropchan, J.; Nabulsi, N.; Carson, R.E.; et al. Social status and demographic effects of the kappa opioid receptor: A PET imaging study with a novel agonist radiotracer in healthy volunteers. Neuropsychopharmacology 2019, 44, 1714-1719. [CrossRef]

192. Ashok, A.H.; Myers, J.; Marques, T.R.; Rabiner, E.A.; Howes, O.D. Reduced mu opioid receptor availability in schizophrenia revealed with $\left[{ }^{11} \mathrm{C}\right]$ carfentanil positron emission tomographic Imaging. Nat. Commun. 2019, 10, 4493-4502. [CrossRef]

193. Prossin, A.R.; Zalcman, S.S.; Heitzeg, M.M.; Koch, A.E.; Campbell, P.L.; Phan, K.L.; Stohler, C.S.; Zubieta, J.K. Dynamic interactions between plasma IL-1 family cytokines and central endogenous opioid neurotransmitter function in humans. Neuropsychopharmacology 2015, 40, 554-565. [CrossRef]

194. Schrepf, A.; Harper, D.E.; Harte, S.E.; Wang, H.; Ichesco, E.; Hampson, J.P.; Zubieta, J.K.; Clauw, D.J.; Harris, R.E. Endogenous opioidergic dysregulation of pain in fibromyalgia: A PET and fMRI study. Pain 2016, 157, 2217-2225. [CrossRef] [PubMed]

195. Gorelick, D.A.; Kim, Y.K.; Bencherif, B.; Boyd, S.J.; Nelson, R.; Copersino, M.; Endres, C.J.; Dannals, R.F.; Frost, J.J. Imaging brain mu-opioid receptors in abstinent cocaine users: Time course and relation to cocaine craving. Biol. Psychiatry 2005, 57, 1573-1582. [CrossRef] [PubMed]

196. Gorelick, D.A.; Kim, Y.K.; Bencherif, B.; Boyd, S.J.; Nelson, R.; Copersino, M.L.; Dannals, R.F.; Frost, J.J. Brain mu-opioid receptor binding: Relationship to relapse to cocaine use after monitored abstinence. Psychopharmacology 2008, 200, 475-486. [CrossRef] [PubMed]

197. Martinez, D.; Slifstein, M.; Matuskey, D.; Nabulsi, N.; Zheng, M.-Q.; Lin, S.-F.; Ropchan, J.; Urban, N.; Grassetti, A.; Chang, D.; et al. Kappa-opioid receptors, dynorphin, and cocaine addiction: A positron emission tomography study. Neuropsychopharmacology 2019, 44, 1720-1727. [CrossRef]

198. Narendran, R.; Tollefson, S.; Himes, M.L.; Paris, J.; Lopresti, B.; Ciccocioppo, R.; Scott Mason, N. Nociceptin receptors upregulated in cocaine use disorder: A positron emission tomography imaging study using [ ${ }^{11}$ C]NOP-1A. Am. J. Psychiarty 2019, 176, 468-476. [CrossRef]

199. Heinz, A.; Reimold, M.; Wrase, J.; Hermann, D.; Croissant, B.; Mundle, G.; Dohmen, B.M.; Braus, D.F.; Schumann, G.; Machulla, H.J.; et al. Correlation of stable elevations in striatal mu-opioid receptor availability in detoxified alcoholic patients with alcohol craving: A positron emission tomography study using carbon ${ }^{11}$ C-labeled carfentanil. Arch. Gen. Psychiatry 2005, 62, 57-64. [CrossRef]

200. Turton, S.; Myers, J.F.M.; Mick, I.; Colasanti, A.; Venkataraman, A.; Durant, C.; Waldman, A.; Brailsford, A.; Parkin, M.C.; Dawe, G.; et al. Blunted endogenous opioid release following an oral dexamphetamine challenge in abstinent alcohol-dependent individuals. Mol. Psychiatry 2018. [CrossRef]

201. Williams, T.M.; Davies, S.J.C.; Taylor, L.G.; Daglish, M.R.C.; Hammers, A.; Brooks, D.J.; Nutt, D.J.; Lingford-Hughes, A. Brain opioid receptor binding in early abstinence from alcohol dependence and relationship to craving: An $\left[{ }^{11} \mathrm{C}\right]$ diprenorphine PET study. Eur. Neuropsychopharmacol. 2009, 19, 740-748. [CrossRef] 
202. Hermann, D.; Hirth, N.; Reimold, M.; Batra, A.; Smolka, M.N.; Hoffmann, S.; Kiefer, F.; Noori, H.R.; Sommer, W.H.; Reischl, G.; et al. Low mu-opioid receptor status in alcohol dependence identified by combined positron emission tomography and post-mortem brain analysis. Neuropsychopharmacology 2016, 42, 606-614. [CrossRef]

203. Weerts, E.M.; Wand, G.S.; Kuwabara, H.; Munro, C.A.; Dannals, R.F.; Hilton, J.; Frost, J.J.; McCaul, M.E. Positron emission tomography imaging of $\mathrm{Mu}$ - and Delta-opioid receptor binding in alcohol-dependent and healthy control subjects. Alcohol. Clin. Exp. Res. 2011, 35, 2162-2173. [CrossRef]

204. Wand, G.S.; Weerts, E.M.; Kuwabara, H.; Frost, J.J.; Xu, X.; McCaul, M.E. Naloxone-induced cortisol predicts mu opioid receptor binding potential in specific brain regions of healthy subjects. Psychoneuroendocrinology 2011, 36, 1453-1459. [CrossRef] [PubMed]

205. Wand, G.S.; Weerts, E.M.; Kuwabara, H.; Wong, D.F.; Xu, X.; McCaul, M.E. The relationship between naloxone-induced cortisol and mu opioid receptor availability in mesolimbic structures is disrupted in alcohol dependent subjects. Alcohol 2012, 46, 511-517. [CrossRef] [PubMed]

206. Ray, R.; Ruparel, K.; Newberg, A.; Wileyto, E.P.; Loughead, J.W.; Divgi, C.; Blendy, J.A.; Logan, J.; Zubieta, J.-K.; Lerman, C. Human Mu Opioid Receptor (OPRM1 A118G) polymorphism is associated with brain mu-opioid receptor binding potential in smokers. Proc. Natl. Acad. Sci. USA 2011, 108, 9268-9273. [CrossRef] [PubMed]

207. Domino, E.F.; Hirasawa-Fujita, M.; Ni, L.; Guthrie, S.K.; Zubieta, J.K. Regional brain [ ${ }^{11}$ C]carfentanil binding following tobacco smoking. Progr. Neuro-Psychopharmacol. Biol. Psychiatry 2015, 59, 100-104. [CrossRef]

208. Nuechterlein, E.B.; Ni, L.; Domino, E.F.; Zubieta, J.K. Nicotine-specific and non-specific effects of cigarette smoking on endogenous opioid mechanisms. Progr. Neuro-Psychopharmacol. Biol. Psychiatry 2016, 69, 69-77. [CrossRef]

209. Weerts, E.M.; Wand, G.S.; Kuwabara, H.; Xu, X.; Frost, J.J.; Wong, D.F.; McCaul, M.E. Association of smoking with mu-opioid receptor availability before and during naltrexone blockade in alcohol-dependent subjects. Addict. Biol. 2014, 19, 733-742. [CrossRef]

210. Kuwabara, H.; Heishman, S.J.; Brasic, J.R.; Contoreggi, C.; Cascella, N.; Mackowick, K.M.; Taylor, R.; Rousset, O.; Willis, W.; Huestis, M.A.; et al. Mu opioid receptor binding correlates with nicotine dependence and reward in smokers. PLoS ONE 2014, 9, e113694. [CrossRef]

211. Guterstam, J.; Jayaram-Lindström, N.; Cervenka, S.; Frost, J.J.; Farde, L.; Halldin, C.; Franck, J. Effects of amphetamine on the human brain opioid system-A positron emission tomography study. Int. J. Neuropsychopharmacol. 2013, 16, 763-769. [CrossRef]

212. Colasanti, A.; Searle, G.E.; Long, C.J.; Hill, S.P.; Reiley, R.R.; Quelch, D.; Erritzoe, D.; Tziortzi, A.C.; Reed, L.J.; Lingford-Hughes, A.; et al. Endogenous opioid release in the human brain reward system induced by acute amphetamine administration. Biol. Psychiatry 2012, 72, 371-377. [CrossRef]

213. Mick, I.; Myers, J.; Stokes, P.R.A.; Erritzoe, D.; Colasanti, A.; Bowden-Jones, H.; Clark, L.; Gunn, R.N.; Rabiner, E.A.; Searle, G.E.; et al. Amphetamine induced endogenous opioid release in the human brain detected with $\left[{ }^{11} \mathrm{C}\right]$ carfentanil PET: Replication in an independent cohort. Int. J. Neuropsychopharmacol. 2014, 17, 2069-2074. [CrossRef]

214. Quelch, D.R.; Katsouri, L.; Nutt, D.J.; Parker, C.A.; Tyacke, R.J. Imaging endogenous opioid peptide release with $\left[{ }^{11} \mathrm{C}\right]$ carfentanil and $\left[{ }^{3} \mathrm{H}\right]$ diprenorphine: Influence of agonist-induced internalization. J. Cereb. Blood Flow. Metab. 2014, 34, 1604-1612. [CrossRef] [PubMed]

215. Mick, I.; Myers, J.; Ramos, A.C.; Stokes, P.R.A.; Erritzoe, D.; Colasanti, A.; Gunn, R.N.; Rabiner, E.A.; Searle, G.E.; Waldman, A.D.; et al. Blunted endogenous opioid release following an oral amphetamine challenge in pathological gamblers. Neuropsychopharmacology 2016, 41, 1742-1750. [CrossRef] [PubMed]

216. Majuri, J.; Joutsa, J.; Arponen, E.; Forsback, S.; Kaasinen, V. Dopamine synthesis capacity correlates with mu-opioid receptor availability in the human basal ganglia: A triple-tracer PET study. NeuroImage 2018, 183, 1-6. [CrossRef] [PubMed]

217. Bencherif, B.; Guarda, A.S.; Colantuoni, C.; Ravert, H.T.; Dannals, R.F.; Frost, J.J. Regional mu-opioid receptor binding in insular cortex is decreased in bulimia nervosa and correlates inversely with fasting behavior. $J$. Nucl. Med. 2005, 46, 1349-1351. [PubMed]

218. Karlsson, H.K.; Tuominen, L.; Tuulari, J.J.; Hirvonen, J.; Parkkola, R.; Helin, S.; Salminen, P.; Nuutila, P.; Nummenmaa, L. Obesity is associated with decreased mu-opioid but unaltered dopamine $\mathrm{D}_{2}$ receptor availability in the brain. J. Neurosci. 2015, 35, 3959-3965. [CrossRef] [PubMed] 
219. Joutsa, J.; Karlsson, H.K.; Majuri, J.; Nuutila, P.; Helin, S.; Kaasinen, V.; Nummenmaa, L. Binge eating disorder and morbid obesity are associated with lowered mu-opioid receptor availability in the brain. Psychiatry Res. Neuroimaging 2018, 276, 41-45. [CrossRef] [PubMed]

220. Karlsson, H.K.; Tuulari, J.J.; Tuominen, L.; Hirvonen, J.; Honka, H.; Parkkola, R.; Helin, S.; Salminen, P.; Nuutila, P.; Nummenmaa, L. Weight loss after bariatric surgery normalizes brain opioid receptors in morbid obesity. Mol. Psychiatry 2016, 21, 1057-1062. [CrossRef]

221. Tuominen, L.; Tuulari, J.; Karlsson, H.; Hirvonen, J.; Helin, S.; Salminen, P.; Parkkola, R.; Hietala, J.; Nuutila, P.; Nummenmaa, L. Aberrant mesolimbic dopamine-opiate interaction in obesity. NeuroImage 2015, 122, 80-86. [CrossRef]

222. Tuulari, J.J.; Tuominen, L.; de Boer, F.E.; Hirvonen, J.; Helin, S.; Nuutila, P.; Nummenmaa, L. Feeding releases endogenous opioids in humans. J. Neurosci. 2017, 37, 8284-8291. [CrossRef]

223. Nummenmaa, L.; Saanijoki, T.; Tuominen, L.; Hirvonen, J.; Tuulari, J.J.; Nuutila, P.; Kalliokoski, K. Mu-opioid receptor system mediates reward processing in humans. Nat. Commun. 2018, 9, 1500. [CrossRef]

224. Saanijoki, T.; Nummenmaa, L.; Tuulari, J.J.; Tuominen, L.; Arponen, E.; Kalliokoski, K.K.; Hirvonen, J. Aerobic exercise modulates anticipatory reward processing via the mu-opioid receptor system. Hum. Brain Mapp. 2018, 39, 3972-3983. [CrossRef] [PubMed]

225. Hiura, M.; Sakata, M.; Ishii, K.; Toyohara, J.; Oda, K.; Nariai, T.; Ishiwata, K. Central mu-opioidergic system activation evoked by heavy and severe-intensity cycling exercise in humans: A pilot study using positron emission tomography with ${ }^{11}$ C-carfentanil. Int. J. Sports Med. 2017, 38, 19-26. [PubMed]

226. Pert, C.B.; Snyder, S.H. Opiate receptor binding-Enhancement by opiate administration in vivo. Biochem. Pharmacol. 1976, 25, 847-853. [CrossRef]

227. Burns, J.A.; Kroll, D.S.; Feldman, D.E.; Liu, C.K.; Manza, P.; Wiers, C.E.; Volkow, N.D.; Wang, G.-J. Molecular imaging of opioid and dopamine systems: Insights into the pharmacogenetics of opioid use disorders. Front. Psychiatry 2019, 10, 626. [CrossRef] [PubMed]

228. Gu, Z.-H.; Wang, B.; Kou, Z.-Z.; Bai, Y.; Chen, T.; Dong, Y.-L.; Li, H.; Li, Y.-Q. Endomorphins: Promising endogenous opioid peptides for the development of novel analgesics. Neurosignals 2017, 25, 98-116. [CrossRef] [PubMed]

229. Redila, V.A.; Chavkin, C. Stress-induced reinstatement of cocaine seeking is mediated by the kappa opioid system. Psychopharmacology 2008, 200, 59-70. [CrossRef] [PubMed]

(C) 2019 by the authors. Licensee MDPI, Basel, Switzerland. This article is an open access article distributed under the terms and conditions of the Creative Commons Attribution (CC BY) license (http://creativecommons.org/licenses/by/4.0/). 